\title{
Structure and Potential Cellular Targets of HAMLET-like Anti-Cancer Compounds made from Milk Components
}

\author{
Emma M. Rath ${ }^{1}$, Anthony P. Duff ${ }^{2}$, Anders P. Håkansson ${ }^{3,4}$, Catherine S. Vacher ${ }^{1}$, Guo Jun Liu ${ }^{2}$, Robert B. Knott ${ }^{2}$, W. \\ Bret Church ${ }^{1}$ \\ ${ }^{1}$ Faculty of Pharmacy, University of Sydney, Sydney, New South Wales 2006, Australia; 2 ANSTO, Lucas Heights, \\ Sydney, New South Wales 2234, Australia; ${ }^{3}$ Division of Experimental Infection Medicine, Lund University, 20502 \\ Malmö, Sweden; ${ }^{4}$ Department of Microbiology and Immunology, University at Buffalo, State University of New York, \\ Buffalo, New York 14214, USA.
}

Received, July 5, 2015; Revised, October 26, 2015; Accepted, November 14, 2015; Published, November 14, 2015.

\begin{abstract}
The HAMLET family of compounds (Human Alpha-lactalbumin Made Lethal to Tumours) was discovered during studies on the properties of human milk, and is a class of protein-lipid complexes having broad spectrum anti-cancer, and some specific anti-bacterial properties. The structure of HAMLETlike compounds consists of an aggregation of partially unfolded protein making up the majority of the compound's mass, with fatty acid molecules bound in the hydrophobic core. This is a novel protein-lipid structure and has only recently been derived by small-angle X-ray scattering analysis. The structure is the basis of a novel cytotoxicity mechanism responsible for anti-cancer activity to all of the around 50 different cancer cell types for which the HAMLET family has been trialled. Multiple cytotoxic mechanisms have been hypothesised for the HAMLET-like compounds, but it is not yet clear which of those are the initiating cytotoxic mechanism(s) and which are subsequent activities triggered by the initiating mechanism(s). In addition to the studies into the structure of these compounds, this review presents the state of knowledge of the anti-cancer aspects of HAMLET-like compounds, the HAMLET-induced cytotoxic activities to cancer and non-cancer cells, and the several prospective cell membrane and intracellular targets of the HAMLET family. The emerging picture is that HAMLET-like compounds initiate their cytotoxic effects on what may be a cancer-specific target in the cell membrane that has yet to be identified.
\end{abstract}

This article is open to POST-PUBLICATION REVIEW. Registered readers (see "For Readers") may comment by clicking on ABSTRACT on the issue's contents page.

\section{INTRODUCTION}

HAMLET-like compounds characterised to date consist of partially-unfolded protein, usually a milk protein, complexed with oleic acid (1), a similar fatty acid $(2,3)$, or sodium oleate $(4,5)$. The protein is partially unfolded and the available structural evidence suggests that the protein polypeptide, referred to in this review simply as protein, is partially folded around the oleate molecules that are aggregated in the centre of the complex $(5,6)$. The fatty acid is in the free monomeric form, which may make membranes and membrane proteins particularly sensitive to it (Figure 1), and is not in the triglyceride form of the oleic acid in olive oil. The first discovered member of this family is HAMLET - Human Alpha-lactalbumin Made LEthal to Tumours. During studies into the anti-bacterial properties of human milk, it was observed that one of the milk fractions induced cell death in the cancer cells used to investigate host bacterial infection (7). The active ingredient, HAMLET, was identified as composed of the $\alpha$-lactalbumin protein and oleic acid from the human milk (1). The column chromatography fractionation process had unexpectedly and serendipitously created the HAMLET compound having novel anti-cancer properties that the milk protein alone does not possess. When cow's milk protein $\alpha$-lactalbumin is used instead of the human version of the protein to create the complex with oleate, the complex is known as BAMLET - Bovine Alpha-lactalbumin Made LEthal to Tumours (8).

Correspondance Author: Dr W. Bret Church, Faculty of Pharmacy, Science Road, University of Sydney, NSW 2006, Australia. Email: bret.church@sydney.edu.au 
HAMLET-like compounds can be created from a range of proteins and a few fatty acid variants, and the structural characteristics of this class of compound are reviewed. Methods other than column chromatography, involving heating or high $\mathrm{pH}$ conditions to unfold the protein and the mixing of a carefully controlled amount of oleic acid or fatty acid anion (9-12), are also used to prepare HAMLET-like compounds.

HAMLET-like compounds have generated interest in several research groups for two main reasons:

1) In vitro, HAMLET and BAMLET compounds show cytotoxicity to over 50 cancer cell lines $(7,13-20)$ including cancer cells resistant to cell death (21) while most primary cell cultures investigated, with the exception of blood cells, show resistance to toxicity from HAMLET-like compounds $(7,13,14)$. Embryonic cells (7) and immortalised non-cancer cells $(7,14,16,22)$ are sensitive to HAMLET. A summary of results of HAMLET-like compounds on cell lines and primary cells is provided in Figure 2 and Supplementary Table 1, and is informative for the analyses of the mechanistic studies into HAMLET's modes of action and potential targets.

2) In vivo experiments demonstrated HAMLET and BAMLET anti-cancer activity and showed no toxicity. The researchers who discovered HAMLET have shown HAMLET to reduce tumours without toxic side effects in vivo in human and mouse orthotopic bladder cancer $(23,24)$, in orthotopic glioblastoma tumours in nude rats (25), and in mice predisposed to colon cancer (26). HAMLET treatment resulted in a reduction of warts and no signs of toxicity in both immunocompetent and immunosuppressed patients (27). An independent group of researchers showed that BAMLET administered by catheter instillation reduced orthotopic bladder tumours without toxicity in rats (14).

The structure of HAMLET-like compounds and how the biological effects are a result of this structure are becoming matters of consensus by researchers in the field, and form an important basis for this review.

Twenty years of research have revealed numerous intracellular targets for the HAMLETlike compounds and have shown HAMLETinduced effects on the cell membrane and its ion fluxes. It is not yet clear which one initiates the cascade of effects that leads to cell death. Recent studies are focussed on the membrane protein effects as possible initiators of the subsequent intracellular effects and differing modes of cell death in different cell types (28-33). In addition to presenting a comprehensive survey of the constellation of multiple cell membrane and intracellular mechanisms associated with HAMLET-induced cell death, this review synthesises the voluminous and sometimes contradictory information and offers speculative but plausible explanations for HAMLET cell death mechanisms. An example of confounding results is that HAMLET appears to be deactivated by extracellular calcium $(4,29,34)$, and yet intracellular calcium may be necessary for the HAMLET cytotoxic effect to occur $(7,28)$.

An open question remains as to whether the complex would be formed by conditions in the stomach when milk containing the HAMLET ingredients is ingested. HAMLET-like compounds also possess promising anti-bacterial potential, not reviewed in this paper, killing Streptococcus pneumoniae (35) and resensitising methicillin-resistant Staphylococcus aureus (MRSA) as well as other drug-resistant bacterial organisms to antibiotics so that these bacteria are killed when treated with a combination of HAMLET and methicillin or other antibiotics $(36,280)$.

\section{CYTOTOXICITY TO CANCER AND NON- CANCER CELLS \\ In vitro cytotoxicity}

Cytotoxicity of HAMLET-like compounds has been reported by 12 different research groups in 23 publications on a wide range of cancer cell lines in vitro and found to be cytotoxic at doses that the controls, often the $\alpha$-lactalbumin protein without oleic acid, were not cytotoxic, or at doses that were not cytotoxic to non-cancer cells. Supplementary Table 1 lists the 50\% lethal doses $\left(\mathrm{LD}_{50}\right)$ and viability assays for cancer and noncancer cell lines and for non-cancer primary cells treated with HAMLET-like compounds. In some cases, different research groups have reported different $\mathrm{LD}_{50}$ values for the same cell lines, and this is due to differences in the amount of active oleate ingredient in the compounds in addition to differences in experimental conditions and protocols. This highlights that cytotoxicity for cancer and non-cancer cells can only be readily compared for experiments using the same HAMLET-like compound under the same conditions. These comparisons are shown in 
Figure 2 and show the trend that cancer cell lines are more sensitive to HAMLET-induced cell death than non-cancer primary cells. Håkansson et al. (Figure 2A (7)) found that the human epithelial cancer cell lines A498 kidney, A549 lung, NCI-H292 bronchial, HT29 intestine, $\mathrm{CaCO} 2$ intestine, J82 bladder, and HTB9 bladder are more sensitive to HAMLET than primary human epithelial cells from kidney, nasopharynx, bladder, and urinary tract. Håkansson et al. (Figure 2B (37)) also found that the human epithelial cancer cell line A549 lung is more sensitive to HAMLET than primary human renal epithelial cells. Both Gustafsson et al. (Figure 2D (18)) and Zhang et al. (Figure 2G (38)) found that brain-derived glioma cancers are more sensitive to HAMLET than brain-derived non-cancer astrocytes. However, for non-blood cells, there are 2 outliers to this trend. Non-cancer primary keratinocytes are as sensitive to HAMLET as cancer cells, and colorectal cancer cell line $\mathrm{CaCO} 2$ is as resistant to HAMLET as non-cancer primary human umbilical vein endothelial cells (Figure 2M (13)). All the primary blood cells assayed are more sensitive to HAMLET than cancer cells (Figure 2M (13)) and so don't conform to this trend either. Thus, there is no dose at which HAMLET kills all cancer cells and spares all non-cancer cells. Another trend shown by Figure 2 is that leukaemias and lymphomas are generally more sensitive to HAMLET-induced death than carcinomas (Figure 2J (39), Figure 2L (16) and Figure 2M (13)), and primary non-cancer blood cells are more sensitive than primary noncancer epithelial cells (Figure 2A (7) and Figure 2M (13)). However, although HAMLET-like compounds have been assayed on 50 different cancer cell lines, the literature contains only 11 types of primary cell cultures, and thus it remains to be seen whether these trends will hold when more types of primary cells are investigated. The 6 immortalised non-cancer cells lines investigated have sensitivities to HAMLET that are in the same range as the cancer cell lines $(7,14,16,22)$. It is not yet clear whether this is due to a general toxicity of HAMLET to healthy cells, or whether HAMLET is targeting a fundamental cancer-like characteristic that is possessed by immortalised non-cancer cell lines. It is also not clear how other factors present in the in vivo environment may provide an increased difference in sensitivity of immature and cancer cells compared to healthy differentiated cells.
In addition to the 50 different cancer cell lines, HAMLET was found to be cytotoxic to 2 embryonic primary cell types (7). These results are the basis for the reports that HAMLET is selectively cytotoxic to cells with an immature phenotype (7). Generally, the more immature a tumour is, the more aggressive it is (40-42). It is a goal of cancer research to find compounds that are effective in killing undifferentiated aggressive cancers $(41,43)$, and interest in HAMLET stems from HAMLET's ability to kill immature cells such as cancer cells and the possibility that this cytotoxicity is selective for immature cells over healthy differentiated cells.

\section{In vivo cytotoxicity and efficacy}

HAMLET and BAMLET reduced bladder cancer tumours without toxicity to healthy tissue in humans (23), rats (14), and mice (24). Nine human patients awaiting transurethral surgery for bladder cancer received HAMLET instillations via urinary catheter for 5 consecutive days (23). Massive shedding of tumour cells into the urine and a reduction in tumour size occurred, and no cell death was detected in biopsies of healthy tissue adjacent to the tumours (23). In an orthotopic bladder cancer model of immunocompetent rats, BAMLET treatment resulted in tumour growth inhibition and long term survivor numbers that were comparable to the control treatment that consisted of what is currently the most effective treatment for noninvasive bladder cancer (Bacillus CalmetteGuérin), and found no evident BAMLET sideeffects to bladder walls, rat body-weight change or general well-being (14). In an orthotopic bladder cancer model of immunocompetent mouse, HAMLET treatment resulted in delayed tumour development and reduced tumour volumes (24). TUNEL staining showed that tumour tissue underwent apoptosis and adjacent healthy tissue did not (24). HAMLET delivered by a 24 hours intra-cranial infusion reduced orthotopic glioblastoma tumours in rats and prolonged their survival without signs of toxicity (25). MRI showed no oedema or tissue damage in the surrounding healthy brain, and histopathology showed no significant signs of toxicity in surrounding brain parenchyma compared with the control group (25). HAMLET treatment taken orally resulted in a reduction of the number of colon tumours and longer survival of tumourbearing mice predisposed to colon cancer (26). 


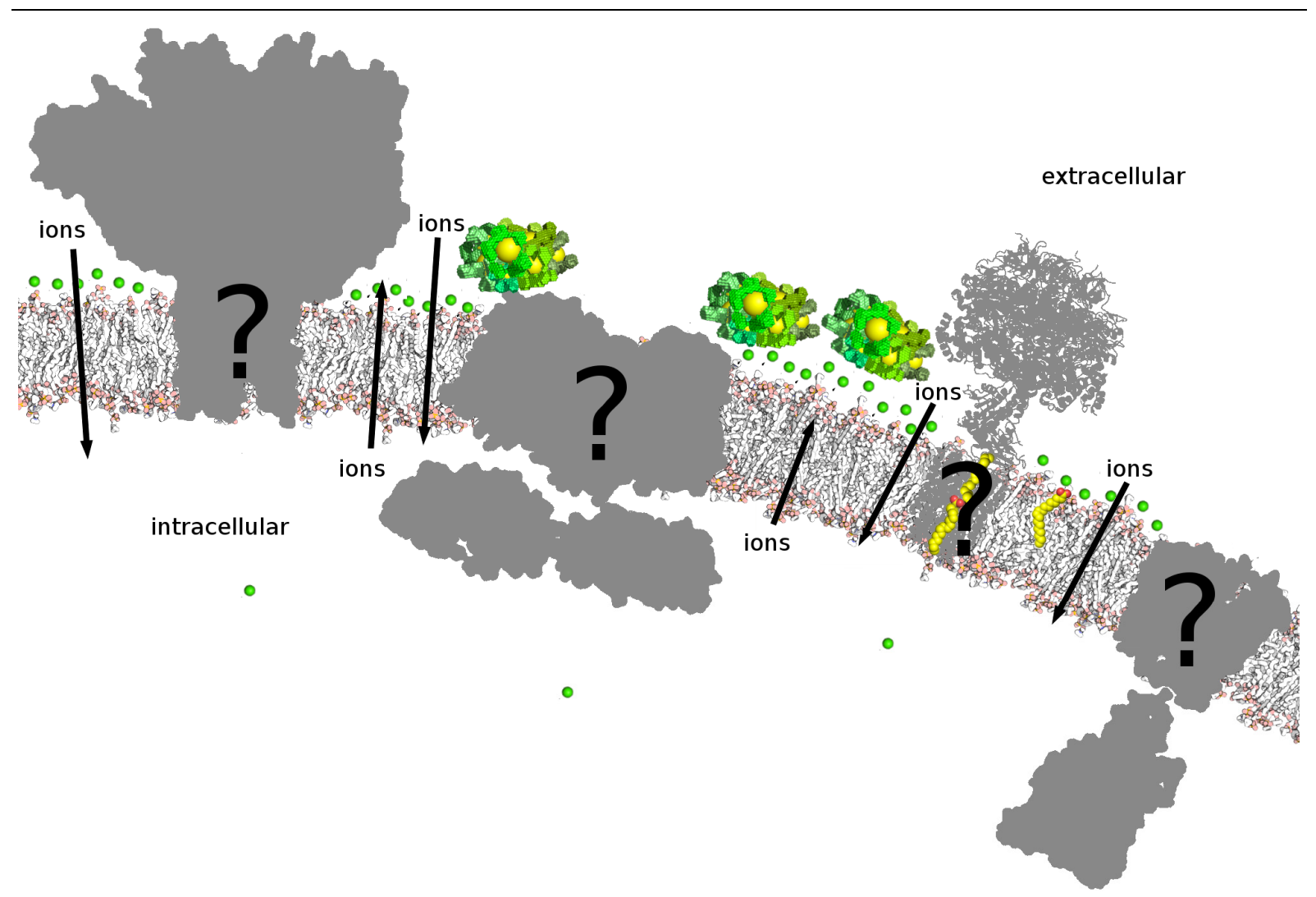

Figure 1. The cellular membrane showing HAMLET (green and yellow aggregates, adapted from (6)) on the extracellular side, and a kinked oleic acid (yellow and red) in the free fatty acid form, spanning the outer bilayer leaflet (grey and pink). The oleic acid is shown to scale as being a similar length to the lipids making up the bilayer leaflet. Identification of the HAMLET targets remains unresolved, and some potential membrane targets (sodium channel, sodium exchangers, and ectopic ATP synthase with 2 yellow and red oleates placed in the centre of the c-ring where they are hypothesised to have similar affinity as cardiolipin) are shown in grey with a question mark. Calcium ions (green spheres) are shown stabilising the extracellular side of the plasma membrane, and may have a fundamental role in HAMLET-induced cell death.

Analysis of intestinal segments found that HAMLET-treated mice had normal villi whereas untreated mice had intestinal villus hyperplasia (26). HAMLET was used as a topical cream treatment for skin warts of immunocompetent and immunosuppressed human patients, as warts are induced by papillomaviruses and therefore immune responsive (27). Most of the warts lost volume during HAMLET treatment and most warts had disappeared at the 2 year follow-up in both populations (27). Visual inspection and interview with patients reported no symptoms to healthy skin adjacent to the treated warts (27).
HAMLET compounds are partially deactivated in blood $(4,13)$, and thus these in vivo studies avoided contact with blood. BAMLET is toxic to primary blood cells in vitro $(13,29,44)$ (Figures 2A, 2H, and 2M) and the lack of toxicity of HAMLET and BAMLET to blood cells in vivo may be explained by the fact that the in vivo studies avoided contact with blood and may also be due to HAMLET being deactivated by components in blood upon contact. 

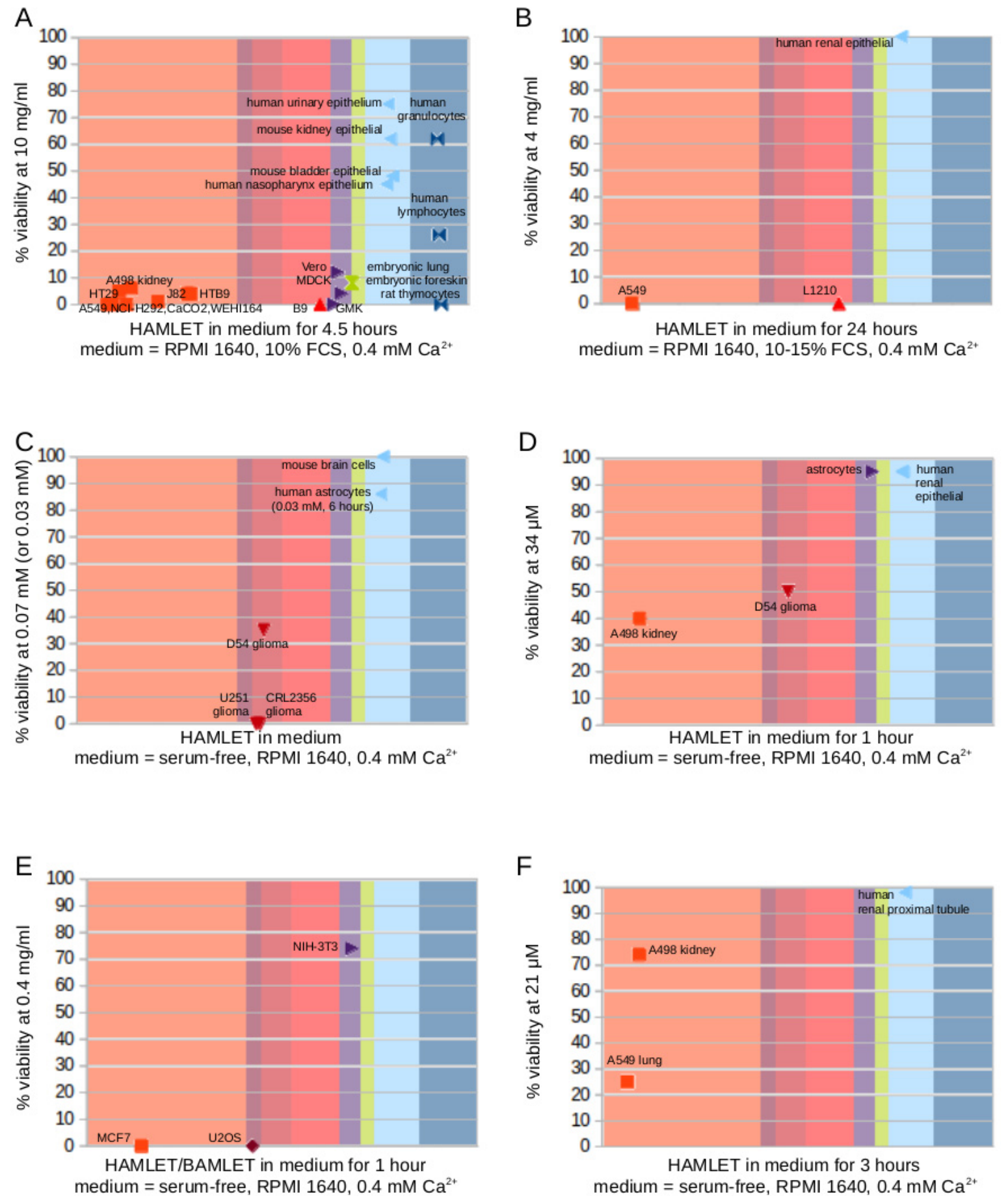

Figure 2. 


\section{Figure 2 Continued...}
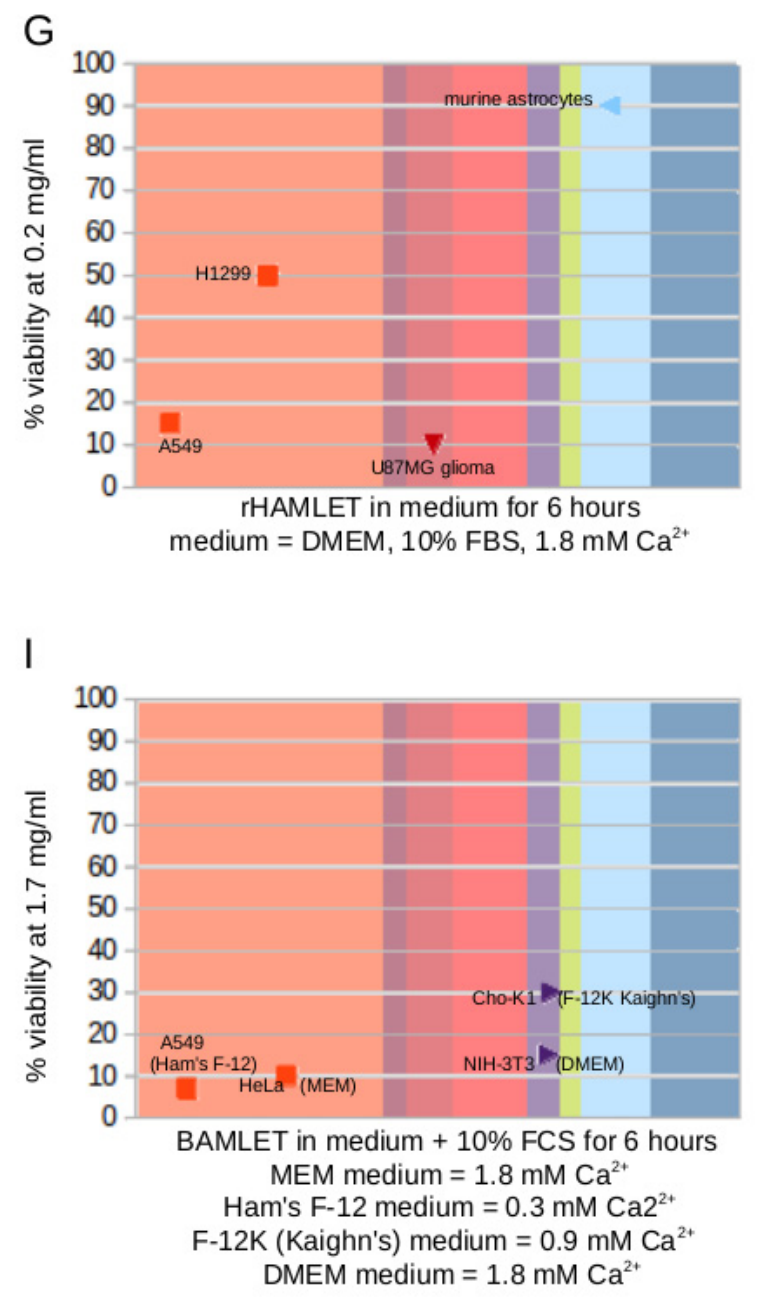

$\mathrm{H}$

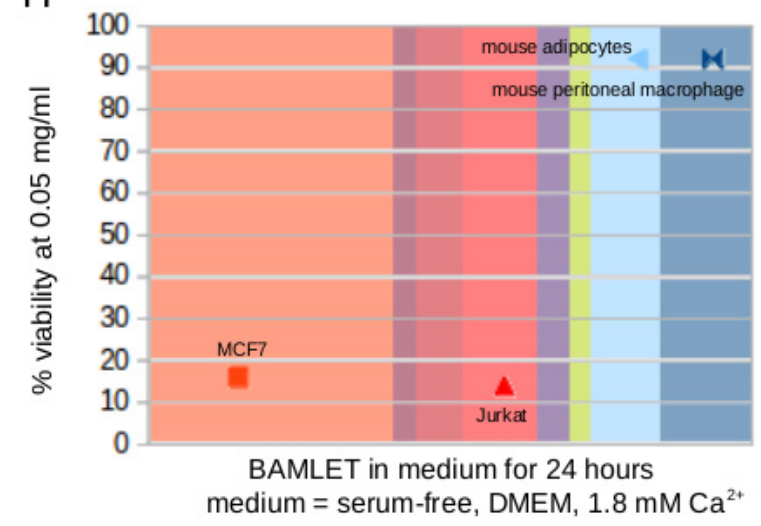

Figure 2. Comparisons of levels of toxicity induced in vitro by HAMLET, BAMLET and other HAMLET-like compounds to cancer and non-cancer cells taken from A (7), B (37), C (25), D (18), E (16), F (28), G (38), H (44), I (22), J (39), K (25), L (16), M (13), N (14), and O (5,44). For each graph, cancer cells are shown on the left and noncancer cells on the right, and are categorised into carcinomas and papillomas (orange), pheochromocytomas, osteosarcomas, and melanoma (magenta), gliomas (dark red), lymphomas and leukaemias (bright red), non-cancerous immortalised cell lines (purple), non-cancerous embryonic cells (green), non-cancerous primary non-blood cells (light blue), and non-cancerous primary blood cells (dark blue). The graph regions are coloured by cell type and the width of a region is proportional to the number of cell types for which assays have been performed. Results for viability assays are presented (graphs A-I), followed by $\mathrm{LD}_{50}$ results (graphs J-O). For cells that are resistant to HAMLET, the $\mathrm{LD}_{50}$ values were not determined, and those cells appear in viability assay graphs only. For cells that are sensitive to HAMLET cytotoxicity, $\mathrm{LD}_{50}$ values were determined and the cells appear in both the viability and $\mathrm{LD}_{50}$ graphs. In graph L, where two values appear for one cell line, one value is for HAMLET and the other for BAMLET. In graph O, the same cell type appears more than once because it was examined with several HAMLET-like species. The descriptive names of cell lines appear in Supplementary Table 1. 


\section{Figure 2 Continued...}

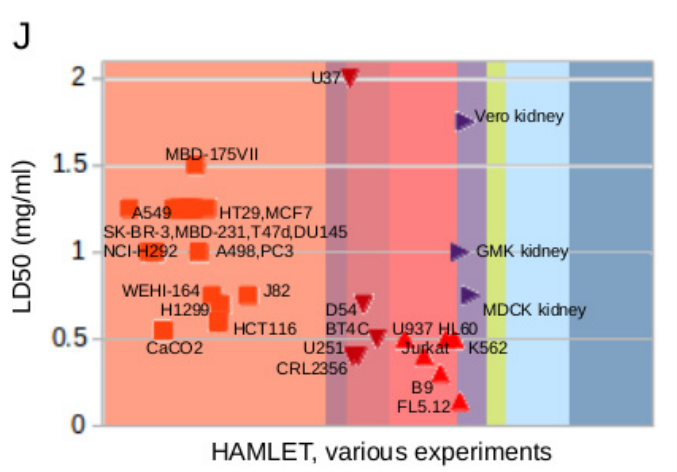

L

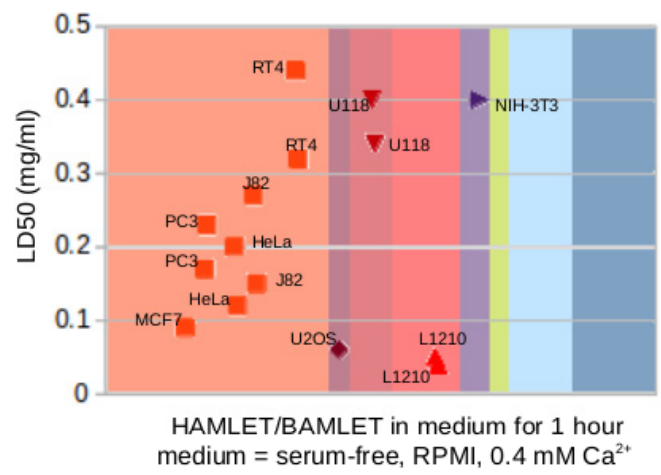

N

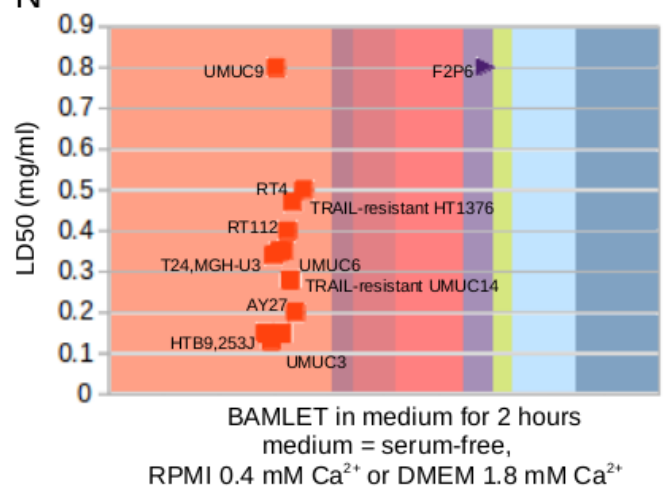

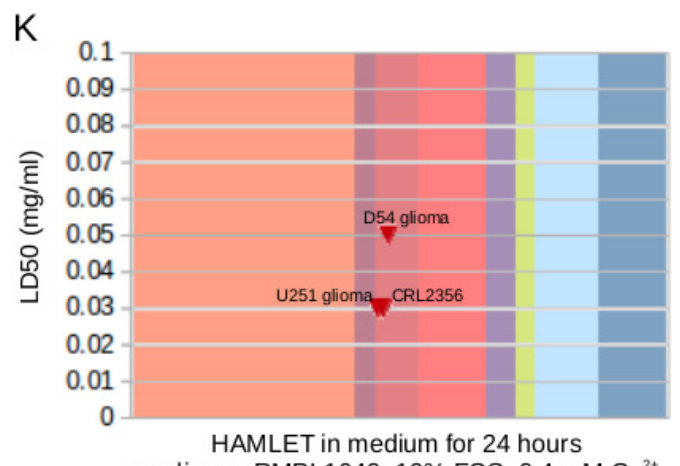

M

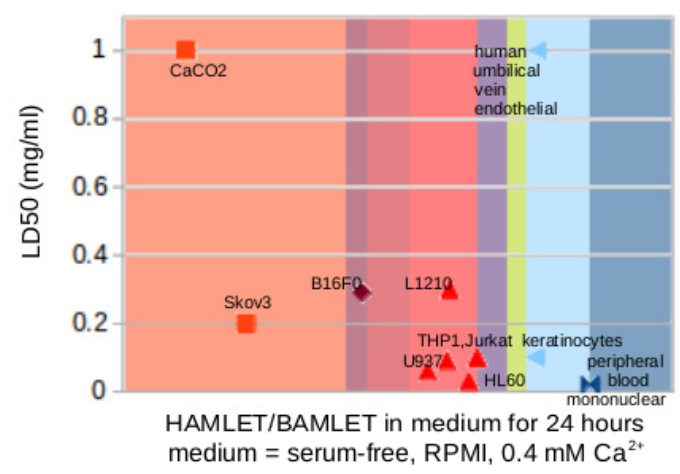

$\mathrm{O}$

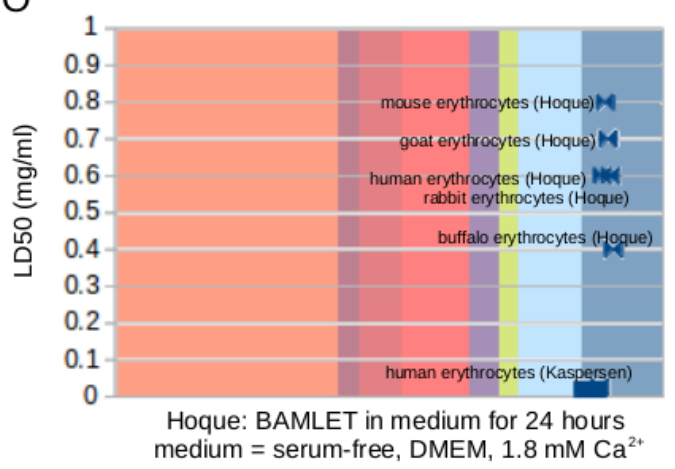

Kaspersen: various BAMLETs in a solution for 4 hours solution $=\mathrm{NaPO}_{4}, \mathrm{NaCl}$

- Carcinomas and papilomas

- Pheochromocytomas, osteosarcomas, and melanoma

₹ Gliomas

$\Delta$ Lymphomas and leukemias

- Non-cancerous immortalised cell lines

x Non-cancerous embryonic cells

4 Non-cancerous primary non-blood cells

Non-cancerous primary blood cells 


\section{STRUCTURE}

\section{Preparation from several proteins}

The most studied HAMLET-like compounds are HAMLET and BAMLET, prepared from oleic acid and either human or bovine $\alpha$-lactalbumin protein, respectively. Other proteins from which cytotoxic HAMLET-like compounds can be made include $\alpha$-lactalbumin of goat (referred to as GAMLET), horse, pig, and camel $(19,46,47)$, and other proteins altogether, such as bovine $\beta$-lactoglobulin $(3,4,17)$, bovine lactoferrin $(48)$, bovine serum albumin (5), pike fish parvalbumin (17), horse lysozyme (referred to as ELOA) (49), recombinant dog milk lysozyme mutant (47), horse heart apo-myoglobin $(47,50)$, chicken ovalbumin (5), recombinant $\beta 2$-microglobulin (47), and human immunoglobulin $G$ (5). Structural changes have been made to $\alpha$-lactalbumin, and it continues to be able to make cytotoxic compounds when complexed with oleic acid. These include chemically cross-linking residues before, during or after adding oleic acid $(44,51)$; binding the protein to relatively large Sepharose 4B beads (44); replacing all the cysteines with alanines so as to remove all disulphide bonds (52); clipping the protein into peptides by proteolytic enzymes (53); or use of synthesised peptides from the various domains having cysteines modified to alanines (54).

Cytotoxic HAMLET-like compounds can be made from many different types of proteins indicating that the HAMLET activity is not due to a specifically folded protein structure.

\section{Oleic acid is the main active component}

It is generally accepted that the main active component of HAMLET-like compounds is the oleate, whether it comes from oleic acid or sodium oleate, as few substitutions of the lipid allow for HAMLET-like cytotoxicity $(4,17,51,53,54)$.

Some studies of HAMLET-like compounds have found that the complex is as cytotoxic to cells as is oleic acid alone when the same amounts of oleic acid are applied as the amounts present in the complexes (13). Other studies found that the protein-lipid complex is more cytotoxic than similar amounts of oleic acid or sodium oleate alone $(3-5,15,17,38,44,50,54)$. It is not yet clear whether these are true differences in cytotoxicity for the different protein carriers of oleate, or whether these different results reflect difficulties in solubilising oleic acid alone for delivery in water-based cellular systems, or are a result of accuracy and precision in measuring the oleate amounts present in the HAMLET-like compounds. It is also not clear whether the mechanisms of cell death induced by HAMLETlike compounds or oleic acid alone are the same.

In a study that further supports this observation, BAMLET protein was linked to Sepharose $4 \mathrm{~B}$ beads - which are unlikely to enter cells - and the BAMLET beads nonetheless exhibited cytotoxicity to red blood cells. With each reuse, the cytotoxicity was reduced (44). These results suggest that the cytotoxic component of BAMLET is oleic acid, which dissociates from the protein to exert the cytotoxic effect, so that less oleate is available next time the BAMLET beads are used.

Increasing the oleate content of a HAMLETlike compound increases its cytotoxicity. The amount of oleate that can be added to a partiallyunfolded protein to form a cytotoxic HAMLETlike compound is approximately 1 oleate per 1 $\mathrm{kDa}$ molecular weight of protein (5). Adding less oleate during preparation than the maximum amount results in less oleate being complexed with protein and approximately correspondingly less cytotoxicity (higher $\mathrm{LD}_{50}$ ) (4). Supplementary Table 2 lists the reported stoichiometries of protein and fatty acid in HAMLET-like compounds made from several proteins by various methods.

Unsaturated cis fatty acids of carbon chain length from 16 to 20 are able to bind $\alpha$-lactalbumin by column chromatography and form HAMLET, while saturated fatty acids or unsaturated trans fatty acids are not (55). The fatty acids that produce the most cytotoxic HAMLETs are C18:1:9 cis (oleic acid) and C18:1:11 cis (vaccenic acid), and others that produced HAMLETs of lesser cytotoxicity are C18:3 cis ( $\alpha$-linolenic acid and $\gamma$-linolenic acid), C18:1:6 cis (petroselinic acid), C18:2 cis (linoleic acid), and C16:1:9 cis (palmitoleic acid) (55). When complexed with bovine $\beta$-lactoglobulin, oleic acid and linoleic acid have similar cytotoxicities (3).

In vitro cell death assays of HAMLET and BAMLET frequently use the $\alpha$-lactalbumin protein without oleic acid as the control, and find that the apo-protein is not cytotoxic (3,13$16,21,24,38,44)$. Calcium depleted $\alpha$-lactalbumin takes on the same folded structure as the native 
calcium-bound form (66) and the apo-protein used in cell death assays can be assumed to be folded. However, an in vivo experiment treating bladder cancer in rats by instilling BAMLET into the bladder by catheter found that a high dose of $\alpha$-lactalbumin showed similar tumour-reducing activity as the low dose of BAMLET (14). In this particular case, the apo-protein may have been unfolded by the urine in the bladder, and this result suggests that the unfolded protein may have cytotoxic effects on cancer cells even without oleic acid. If the oleate in HAMLET separates from the protein to exert its cytotoxic effect, then the protein component is probably left in a state of unfoldedness, and in this state it may also exert toxic effects.

The $\alpha$-lactalbumin protein component of HAMLET enters cells and associates with intracellular components $(18,37,56-59)$, as does the $\beta$-lactoglobulin protein component when HAMLET is prepared from that protein (4). It is not known whether the HAMLET protein is folded when it is inside the cell, and unfolded protein inside the cell may fold spontaneously or with the assistance of chaperone proteins $(60,61)$. HAMLET protein inside the cell, whether folded or not, may exert detrimental effects. There is evidence that $\alpha$-lactalbumin triggers apoptosis of mammary cells during weaning, as the regulatory mechanism for breast involution when milk is no longer needed (62). Alpha-lactalbumin protein triggers cell death in normal rat intestinal epithelial cells (63) and virus-transformed mouse leukaemia cells (64). These results and HAMLET results showing HAMLET cytotoxicity superior to that of the oleic acid alone (3$5,15,17,38,44,50,54)$, indicate that $\alpha$-lactalbumin protein is also playing role in HAMLET-induced cell death.

\section{Partially unfolded}

Far-UV circular dichroism (CD) studies show that the protein component of HAMLET-like compounds is in a partially-unfolded molten globule-like state $(1,5,19,51)$. Most methods for associating oleate with protein to make a HAMLET-like compound involve unfolding the protein by heating or by extreme $\mathrm{pH}$ in the presence of the fatty acid anion so that when conditions are returned to physiological and the protein folds again, it folds around the fatty acid anion $(9-11,65)$. The hydrophobic fatty acid is thus associated with the hydrophobic surfaces of the interior of the partially refolded protein, and the protein is inhibited from folding back to its native conformation by the presence of the fatty acid in its interior. As the native structure of $\alpha$-lactalbumin strongly binds a calcium ion (66), some HAMLET preparation methods involve removing calcium with EDTA so as to facilitate the unfolding of the native structure of the polypeptide $(1,9,11)$ and the resulting HAMLET is anticipated to not contain calcium, whereas other methods do not remove calcium $(7,10,12)$. Repeated heating of BAMLET or bovine $\alpha$-lactalbumin without oleate, to temperatures that allow the formation of BAMLET from its protein and fatty acid components, show that the unfolding is a gradual, continuous process (6). The thermal unfolding of ELOA is continuous even though the native equine lysozyme without oleic acid exhibits the expected specific transition points of unfolding (49). Small-angle X-ray scattering (SAXS) studies of BAMLET and other HAMLET-like compounds at the high $\mathrm{pH}$ that allow the formation of HAMLET from its components indicate that the protein's native tertiary structure is altered $(5,6,54)$.

As HAMLET-like compounds can be made by chromatography (1) or from mixing the components without further steps to partially unfold the protein (51), the oleate may associate with the hydrophobic protein interior by entering and exiting the protein during the normal protein breathing that is facilitated at lower dilutions and is suppressed in conditions of molecular crowding (67). HAMLET preparation methods involving sustained partial unfolding by heating or extremes of $\mathrm{pH}$ result in higher amount of incorporated oleate $(5,9)$.

\section{Aggregation}

Chemical cross-linking experiments, gel electrophoresis, particle sizing measurements and turbidity observations show that HAMLET-like compounds aggregate at physiological $\mathrm{pH}$ $(5,7,50,51)$. Supplementary Table 2 lists the measured amounts of protein and oleic acid per aggregate for several HAMLET-like compounds.

Pulse field-gradient NMR studies show that a solution of HAMLET at $\mathrm{pH} 7.5$ contains some native protein (without bound oleic acid), the monomeric molten-globule state protein (bound with oleic acid), and oligomers (bound with oleic acid) (47). Gel filtration column chromatography of BAMLET at $\mathrm{pH} 7.4$ at 15 to $25 \mathrm{mg} / \mathrm{ml}$ 
produces non-cytotoxic monomers and cytotoxic oligomers of $\sim 110 \mathrm{kDa}(51)$. Increasing the ratio of oleic acid to protein results in higher molecular weight oligomers and the almost disappearance of monomers (51). Decreasing BAMLET concentration to $\sim 2 \mathrm{mg} / \mathrm{ml}$ results in monomers eluting, but dynamic light scattering (DLS) shows that the complex is oligomeric in solution (51). Cross-linking $0.1 \mathrm{mg} / \mathrm{ml}$ of BAMLET with glutaraldehyde produces oligomers in SDS-PAGE (51). These results suggest that the amount of oleic acid bound to protein in HAMLET-like compounds and how much protein remains unbound are functions of how much oleic acid is available during preparation of the complex. These results also suggest that the oligomeric BAMLET is a dynamic aggregate in rapid exchange with the monomeric form and the aggregation can be interrupted by the gel filtration column (51).

At $\mathrm{pH} 7.4$, the diameter of the main species of BAMLET aggregates is $7.13 \pm 0.98 \mathrm{~nm}$ as determined by DLS (51). The $\mathrm{pH} 7.5$ solution of $4.2 \mathrm{mg} / \mathrm{ml}$ HAMLET contains three species, which are the native protein of diameter $4 \mathrm{~nm}$, monomeric HAMLET of diameter $4.8 \mathrm{~nm}$, and HAMLET oligomers of diameter 11.4 to $12.2 \mathrm{~nm}$, as determined by pulse field-gradient NMR (47). Modelling of SAXS data at $\mathrm{pH} 9.0$ and RP-HPLC measurements give diameters of 1.8 to $3.6 \mathrm{~nm}$ depending on the BAMLET preparation method and diameters of 1.8 to $2.8 \mathrm{~nm}$ for HAMLET-like compounds made from $\beta$-lactoglobulin, lysozyme, parvalbumin, ovalbumin, albumin or immunoglobulin $\mathrm{G}$ (5). In filtered water, BAMLET has diameters ranging from 227 to 292 $\mathrm{nm}$, as measured by DLS, depending on the BAMLET preparation method (22). Figure 3 shows a plausible model for a BAMLET oligomer at physiological $\mathrm{pH}$.

On a surface, ELOA oligomerises into ring formations (49). HAMLET is able to form rings on negatively-charged membranes at neutral $\mathrm{pH}$ (68). This phenomenon is not thought to be involved with the compound's cytotoxic activity (68).

\section{Novel lipid-binding}

SAXS can provide valuable low-resolution structural information on biological molecules $(69,70)$. When a biological compound in solution contains monodispersed, identical particles, analysis of scattering data allows the modelling of the compound's individual unit (70). However, many different models can produce the same scattering data and thus a given SAXS-derived model is not guaranteed by the scattering data alone to be the actual 3D structure of a given compound $(69,71)$. SAXS studies of BAMLET and other HAMLET-like compounds indicate that the protein tertiary structure is dramatically different to the native fold $(5,6)$. The SAXS data at the high $\mathrm{pH}$ of complex formation has a characteristic bump at high scattering vector (q) values, consisting of a non-sharp first minimum followed by a well-developed secondary maximum, not seen for native proteins, that indicates that the protein is on the outside of the complex $(5,6)$. The characteristic bump occurs at $\mathrm{q}=0.11$ to $0.18 \AA^{-1}$, which corresponds to distances of 35 to $57 \AA$ between the centres of mass of the opposing sides of the shell. The oleate is assumed to be mediating the peripheral protein positioning by being located on the inside (5). The bump is similar to what is produced by core-shell models suggesting that BAMLET has a coreshell-like structure. However, regular, symmetrical core-shell models having traditional homogeneous or gradient density shells cannot be fitted to the SAXS curves of HAMLET-like compounds. At pH 9 to 11 , SAXS data shows that the complex is aggregated and the oleate is proposed to be a spherical micelle formation in the centre decorated with protein on the periphery having a flexible, partially unfolded, irregular conformation (5). Increasing the $\mathrm{pH}$ to $\mathrm{pH} 12$ inhibits the aggregation of BAMLET, revealing the protein as having the form of a winding, irregular, thick, cylindrical thread (6) that is well fitted by an alpha-helical secondary structure and a small amount of protein tertiary structure domains. Figure 3 is a representation of a winding, irregular, thick, cylindrical thread binding fatty acid in its core. This newly reported type of lipid-protein structure $(5,6)$ has been named the "liprotide" model (to denote lipids and partially denatured proteins) (5). Albumin, a protein that has high affinity binding sites for oleic acid $(72,73)$, is one of the proteins from which a HAMLET-like compound can be made. The SAXS-determined high $\mathrm{pH}$ structure of the HAMLET form of albumin having HAMLET-like cytotoxicity to erythrocytes is characteristic of liprotide structures (5) and not of the native protein at high $\mathrm{pH}(74)$ nor of the native protein binding oleate at physiological $\mathrm{pH}$ (75). This 
indicates that the oleate is loosely bound in the HAMLET form of albumin, and does not have the high affinity binding as found in the native form.

These structures can be interpreted as showing that the function of the protein of HAMLET-like compounds is that of a carrier of the fatty acid, keeping the fatty acid watersolubilised and inhibiting it from self-associating to form a fatty, unreactive micelle. When this liprotide structure comes into contact with cell membranes, the fatty acid would have higher affinity for the cell membrane and leave the protein complex. The mechanism of the cell membrane sequestering the fatty acid from BAMLET has been named as the "cargo offloading mechanism" $(5,76)$. If the fatty acid was incorporated into a fatty acid micelle, instead of inside a partially unfolded protein, it could be expected that the majority of the fatty acid would exhibit higher affinity for staying in the micelle. The common structure of HAMLET-like compounds is thought to explain the similar effects exerted on cells by compounds made from different proteins (5).

\section{Secondary structure}

The protein secondary structure of $\alpha$-lactalbumin, $\beta$-lactoglobulin and lysozyme in HAMLET-like compounds is similar to the molten globule forms of those proteins $(4,49,77)$. It has also been observed that the molten-globule state of HAMLET is similar to the state of $\alpha$-lactalbumin interacting with liposomes or micelles (51).

HAMLET protein contains more alpha-helical and less beta-sheet secondary structure than does the unbound molten globule structure of the $\alpha$-lactalbumin protein $(6,77,78)$. The proteolytic fragments of $\alpha$-lactalbumin become more ordered and increase in alpha-helical secondary structure content upon binding oleic acid to form HAMLET-like compounds (53). The HAMLETlike compound formed from horse heart apomyoglobulin maintains its highly helical conformation (50). The BAMLET-like compound formed from bovine $\beta$-lactoglobulin and sodium oleate shows an increase in the protein's mainly beta-sheet structure and less tendency to form intermolecular beta-sheet aggregation upon heating than does the native protein (4). HAMLET-like compounds made of bovine serum albumin, chicken ovalbumin and human immunoglobulin G, proteins that have different secondary structures to each other, show that on forming the complex with oleate, all exhibit a change in secondary structure compared to the native proteins and that the change is different for the different proteins (5).

Proteolysis experiments show that the beta domain of bovine $\alpha$-lactalbumin is amenable to proteolysis and thus must be a flexible region, and the $\mathrm{N}$ - and $\mathrm{C}$-terminal regions are resistant (51). These characteristics remain the same for BAMLET (51).

These results indicate that although the liprotide complexes have a global structural similarity of partially unfolded peripheral protein $(5,6)$, at the detailed level of protein secondary structure, the structure is dependent on the protein in the complex and there is not a universal HAMLET-like protein secondary structure.

\section{Bonding interactions between protein and fatty acid}

The oleate is assumed to bind the protein of HAMLET-like compounds due to both hydrophobic and electrostatic interactions (51). The partial unfolding of the protein is necessary to expose hydrophobic surfaces (53) that are mainly in the core of folded soluble protein. Isothermal titration calorimetry experiments at $\mathrm{pH}$ 7.0 show that the reaction of complexing oleic acid and bovine $\alpha$-lactalbumin is entropy driven, indicating that the formation of complexes occurs as a result of hydrophobic interaction rather than as a result of electrostatic interactions (79). NMR of ELOA shows resonance signals for oleate protons with aromatic residues of the lysozyme protein (49), which indicates that the hydrophobic oleate carbon chain is associating with those residues by hydrophobic interaction.

At physiological $\mathrm{pH}$, free oleic acid is near half-ionisation (80), and thus deprotonated negatively charged oleates are available for electrostatic interaction with positively charged protein residues of the HAMLET protein, as occurs for oleate bound to albumin $(75,81)$. Chemically removing the positive charge of $\alpha$-lactalbumin's lysine side chains removes the ability of the protein to form BAMLET (78). Xie et al. suggest that the negatively charged oleate in BAMLET binds to the positively charged lysine side chains of the protein (78). Alternatively, changing the positive charges of lysine side chains to neutral or negative charges may result in the protein no longer folding, and thus no longer folding around the oleate. The chromatography 
results indicate that the protein having lysine side chains modified to negative charges is no longer folded, and that the protein having lysine side chains modified to neutral remains folded before addition of oleic acid but is no longer folded when oleic acid is added (78). Thus, these results don't unequivocally show that the oleate in HAMLET is binding the protein by electrostatic attraction.

NMR studies show that the oleic acid in HAMLET is not associated with the protein in the same position as the oleic acid in GAMLET, even though the human and goat $\alpha$-lactalbumin proteins are very similar (47). The human and goat $\alpha$-lactalbumin sequences have 10 of the 14 lysines in the same place $(82,83)$. These NMR results are consistent with general hydrophobic interactions rather than specific binding domains for the oleates in the conserved $\alpha$-lactalbumin protein.

Incubating BAMLET with $\mathrm{CaCl}_{2}$ results in the formation of a calcium oleate precipitate making the solution turbid, and further incubation with the calcium chelator EDTA results in the solution becoming clear again (51). The clear solution indicates that EDTA has sequestered the calcium from the calcium oleate precipitation. The oleate has not formed aggregates with itself because a solution containing oleic acid micelles appears turbid, not clear (51). These results indicate that the binding of oleic acid to BAMLET protein is dynamic.

Incubating the proteins ovalbumin, bovine serum albumin (BSA), and immunoglobulin G by themselves at high temperature results in a turbid solution, which indicates that the proteins have partially unfolded and their exposed hydrophobic surfaces are interacting, and adding oleic acid makes the solution clear again, indicating that oleic acid has bound the hydrophobic surfaces of the partially unfolded proteins and thus reduced the aggregation (5).

The general hydrophobic and electrostatic interactions of oleate with HAMLET-like proteins are thought to not involve specific binding cavities in the protein, and this interaction is referred to as "solubilising" the oleic acid $(11,13,51,53,76)$. As when water solubilises salts, the specific water molecules associated with specific salt ions is dynamic and is not generally identified.

Deactivation by blood, albumin, and calcium BAMLET is deactivated in BSA and by fetal bovine serum (FBS) that contains albumin (34). When BSA or FBS is present, the $\mathrm{LD}_{50}$ of BAMLET for HL60 human promyeolcytic leukaemia cells is an order of magnitude higher (eg. the $\mathrm{LD}_{50}$ of around $0.5 \mathrm{mg} / \mathrm{ml}$ increases to around $2 \mathrm{mg} / \mathrm{ml}$ in the presence of $20 \%$ FBS or 5 $\mathrm{mg} / \mathrm{ml} \mathrm{BSA}$ ) (34). Preincubation of isolated mitochondria with BSA partially inhibits HAMLET's and oleic acid's effects on those mitochondria (84). Albumin binds oleic acid with strong affinity $(72,73)$ and it is assumed the albumin sequesters the oleic acid from BAMLET thus deactivating BAMLET (23). The transfer of oleate from BAMLET to the albumin that has higher affinity can be considered another example of the cargo off-loading mechanism.

Calcium in the cell culture medium can drastically reduce BAMLET's cytotoxicity to red blood cells (29). The oleate in HAMLET-like compounds appears to be precipitated out of the complex by calcium. Incubating BAMLET with $\mathrm{CaCl}_{2}$ results in the solution becoming turbid, attributed to the formation of rather insoluble calcium oleate, and the protein secondary structure changes from that of BAMLET to that of native unbound protein (51). Adding more EDTA than calcium ions so that the calcium ions will be sequestered by EDTA results in the CDdetermined protein structure changing back to that of BAMLET (51). When BAMLET is exposed to human blood serum but without contact with the albumin in blood, a calcium-oleate precipitate forms and the remaining BAMLET protein is no longer cytotoxic to cancer cells (4). A high salt concentration also appears to precipitate the oleate out of BAMLET as an oleate salt (4). At low $\mathrm{pH}$ ( $\mathrm{pH} 3$ to 5), both oleate and protein precipitate out of BAMLET solution, and when solubilised again in water, form the cytotoxic BAMLET compound (4). A plausible explanation for this result is that the low $\mathrm{pH}$ causes the protein to unfold enough for the oleate to dissociate from the protein, and the resulting hydrophobic components (unfolded protein and oleic acid) form precipitated aggregates, and the unfolded state of the protein permits the reassociation of the oleate when resolubilised in the higher $\mathrm{pH}$ of water. All together these results demonstrate that HAMLET-like compounds are deactivated by high concentrations of calcium.

Dynamic association of protein and oleate

The oleate in HAMLET-like compounds appears 
to be loosely bound and its association with the protein is in a dynamic state. NMR of ELOA shows that there is an equilibrium between free and bound oleic acid. As ELOA is progressively diluted, more oleic acid dissociates from the protein (76) and the size of ELOA complexes decreases (85). Surface plasmon resonance experiments at $\mathrm{pH} 4.0$ indicate that the amount of sodium oleate that binds partially unfolded bovine $\alpha$-lactalbumin is proportional to the concentration of sodium oleate in the solution, and increases over time until it reaches a plateau limit at a given concentration of oleate (79), indicating that the binding of oleate to BAMLET protein is an equilibrium between bound and unbound oleate. The reversible deactivation of HAMLET-like compounds by calcium described above is a result of this dynamic association of the oleate with the protein. Several residues of $\alpha$-lactalbumin appear to be involved in the binding of this protein to negatively charged membranes because the residues are more protected from NMRmonitored hydrogen-deuterium exchange when the protein is bound versus when not bound (86). These results suggest that binding of BAMLET to a membrane will involve release of its bound oleic acid.

\section{Stability}

HAMLET prepared by the heating method was able to exert its disruptive effects on membrane ion channels even after one month in solution at $4^{\circ} \mathrm{C}$ (31). This suggests that the oleate remains bound to the protein during storage. The biological effect of HAMLET may be due to the instability of the association of oleate with protein (when the complex is in the vicinity of lipid cell membranes for which the oleate has a higher affinity), in which case it is conceivable that over storage time, a decrease in affinity of the oleate for the protein will result in an apparent increase in biological activity, until such storage time is reached that the oleate dissociates from the protein and thus loses its biological HAMLETlike effect. Lyophilised BAMLET looks like protein powder and is how HAMLET-like compounds are usually stored. Should the oleate dissociate from the lyophilised protein over time, it is expected to look oily instead.

When incubated with trypsin or chymotrypsin proteases, native calcium-bound $\alpha$-lactalbumin remains intact after 54 hours of trypsin and 29 hours of chymotrypsin (18). HAMLET starts to degrade after $1 / 2$ hour of trypsin and 1 hour of chymotrypsin and is completely degraded after 2 hours of chymotrypsin and 6 hours of trypsin (18). Partially-unfolded $\alpha$-lactalbumin not bound to either calcium or oleic acid is completely degraded after only 5 minutes of trypsin or chymotrypsin (18).

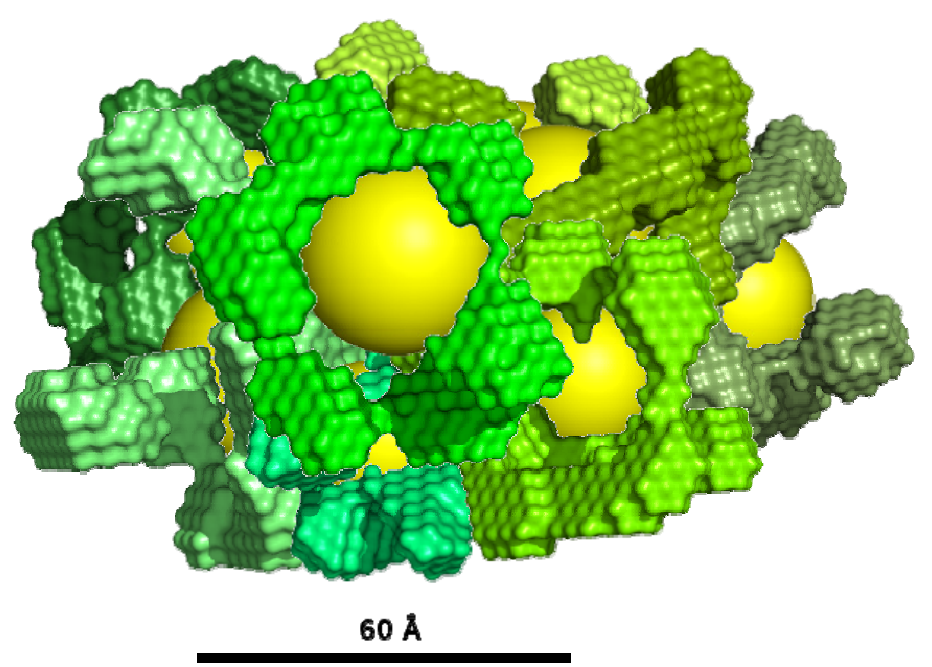

Figure 3. A model of BAMLET showing the protein monomers of Rath et al. (6) (shades of green), that were determined by SAXS at pH 12, with the hypothesised positions of oleic acid oil drops (yellow), as an aggregation of 8 monomers so as to produce the protein molecular weight of $\sim 110 \mathrm{kDa}$ at $\mathrm{pH} 7.4$ of Spolaore et al. (51). Each protein monomer is partially folded around an oleate oil drop which is associated to the hydrophobic core of the protein by hydrophobic interaction. The partially unfolded monomers associate with each other, to create the aggregated complex, by hydrophobic interaction of the exposed hydrophobic protein surfaces that are usually found in the core of the folded protein. 


\section{CELL MEMBRANE TARGETS}

\section{Interactions with ion channels and transporters Sodium fluxes in human cells}

Introduction of amiloride significantly reduces HAMLET-induced cell death in A549 lung carcinoma, HeLa cervical carcinoma, and Jurkat lymphoma cells (28). Amiloride inhibits three types of $\mathrm{Na}^{+}$channels and transporters $-\mathrm{Na}^{+} / \mathrm{H}^{+}$ exchangers (NHE), $\mathrm{Na}^{+} / \mathrm{Ca}^{2+}$ exchangers (NCX), and epithelial sodium channels (EnaC) (Figure 4), and the blockage is dependent on voltage $(87,88)$. In all types of cells, when intracellular $\mathrm{pH}$ decreases, the NHE is activated to maintain $\mathrm{pH}$ at around 7.2 by extruding the excess $\mathrm{H}^{+}$, and is driven by the extracellular $\left[\mathrm{Na}^{+}\right]$gradient maintained by the cell (89). In eukaryote cells, the NCX ensures that cytosolic $\left[\mathrm{Ca}^{2+}\right]$ is low by pumping out excess $\mathrm{Ca}^{2+}$ so that the cell can use the $\left[\mathrm{Ca}^{2+}\right]$ gradient to respond quickly to extracellular signals, and is driven by the extracellular $\left[\mathrm{Na}^{+}\right]$gradient. The NCX can also work in reverse to bring $\mathrm{Ca}^{2+}$ back into the cell (90). In polarised epithelial cells, $\mathrm{Na}^{+}$diffuses into the cell through influx via the $\mathrm{ENaC}$, which provides the electrochemical driving force for outward $\mathrm{K}^{+}$flux via $\mathrm{K}^{+}$channels (91). There are also reports that amiloride can inhibit L-type calcium channels (92), the low threshold (T) calcium channel (93), and mechanosensitive channels (94). HAMLET triggers a rapid increase in intracellular $\left[\mathrm{Na}^{+}\right]$in Jurkat lymphoma cells (28), and this change in $\left[\mathrm{Na}^{+}\right]$is inhibited by amiloride and also by $\mathrm{BaCl}_{2}$ which is a $\mathrm{K}^{+}$ channel inhibitor and oleate precipitator. The $\alpha$-lactalbumin protein alone (that has not had its calcium removed) or oleic acid alone do not trigger changes in $\left[\mathrm{Na}^{+}\right]$(28). Introduction of amiloride effectively inhibits BAMLET-induced lysis of human erythrocytes and of human erythrocyte ghosts that do not contain haemoglobin and do contain spectrin and other cytoskeletal structure (29).

The significant reduction of HAMLETinduced cell death by blockade of epithelial $\left[\mathrm{Na}^{+}\right]$ channels and exchangers with amiloride indicates that HAMLET-induced cell death is a result of $\mathrm{Na}^{+}$influxes. These results may also indicate that HAMLET-induced cell death cannot take place when cytosolic $\mathrm{pH}$ is low or when there is an excess of $\left[\mathrm{Ca}^{2+}\right]$ in the cytosol, because those are the abnormal cell conditions that may occur when amiloride blocks sodium exchangers.

Alternatively, the reduction of HAMLETinduced cell death by amiloride may be due to amiloride deactivating HAMLET. Our own unpublished experiments of incubating $2 \mathrm{mg} / \mathrm{ml}$ BAMLET or bovine $\alpha$-lactalbumin alone or 57 $\mu \mathrm{M}$ oleic acid alone in $50 \mathrm{mM}$ HEPES and 10 $\mathrm{mM}$ of amiloride at $\mathrm{pH} 7.4$ produced precipitation. When BAMLET or protein alone was $0.5 \mathrm{mg} / \mathrm{ml}$ or oleic acid alone was $15 \mu \mathrm{M}$, and amiloride was $1 \mathrm{mM}$, which are similar concentrations to those used in (28), the solutions become cloudy. These observations indicate that amiloride causes precipitation of protein alone, oleic acid alone, and of BAMLET, and that amiloride may deactivate BAMLET.

\section{Potassium fluxes in human cells}

Introduction of $\mathrm{BaCl}_{2}$ reduces HAMLET-induced cell death in A549, HeLa, and Jurkat cells (28). Introduction of both $\mathrm{BaCl}_{2}$ and amiloride inhibits HAMLET-induced cell death even more than either agent alone (28). $\mathrm{Ba}^{2+}$ blocks the wide variety of $\mathrm{K}^{+}$channels that enable both inward and outward $\mathrm{K}^{+}$flux, including $\mathrm{Ca}^{2+}$-activated $\mathrm{K}^{+}$ channels and voltage-dependent $\mathrm{K}^{+}$channels, and the extent of blocking shows dependence on the $\left[\mathrm{K}^{+}\right]$on both sides of the pore (95). HAMLET triggers an increase in intracellular $\left[\mathrm{K}^{+}\right]$in A549 lung carcinoma cells and this change in $\left[\mathrm{K}^{+}\right]$is inhibited by $\mathrm{BaCl}_{2}$ (28). Introduction of tetrandrine (an inhibitor of large conductance $\mathrm{Ca}^{2+}$ activated $\mathrm{K}^{+}$channels) or gadolinium chloride $\left(\mathrm{GdCl}_{3}\right)$ (a general inhibitor of mechanosensitive channels) does not affect HAMLET-induced cell death or ion fluxes (28). Introduction of $\mathrm{BaCl}_{2}$ significantly inhibits BAMLET-induced lysis of human erythrocytes and of human erythrocyte ghosts (29), and erythrocyte membranes possess $\mathrm{Ca}^{2+}$-activated $\mathrm{K}^{+}$channels that have been implicated in erythrocyte cell death (96).

An initial interpretation of these results suggests that HAMLET-induced $\mathrm{K}^{+}$effluxes, or the fluxes of another ion such as $\mathrm{Ca}^{2+}$ that are managed by the $\mathrm{K}^{+}$effluxes, contribute to HAMLET-induced cell death $(28,29)$. The efflux of ions and of potassium ions in particular, plays a significant role in apoptosis (97).

Alternatively, the reduction by $\mathrm{BaCl}_{2}$ of HAMLET-induced cell death is likely due to barium binding to the oleate in HAMLET and 
thus causing partial deactivation, as the divalent barium cation has similar ability to the divalent calcium cation in binding to and precipitating fatty acid anions (98) which have negative charge delocalised over the two oxygen atoms of the carboxyl head. Our own unpublished experiments of incubating $2 \mathrm{mg} / \mathrm{ml}$ BAMLET in $50 \mathrm{mM}$ HEPES and $100 \mathrm{mM}$ of $\mathrm{CaCl}_{2}$ or $\mathrm{BaCl}_{2}$ at $\mathrm{pH} 7.4$ produced a precipitate. In the same unpublished experiments, when BAMLET was $0.5 \mathrm{mg} / \mathrm{ml}$ and $\mathrm{BaCl}_{2}$ was $1 \mathrm{mM}$, which are similar concentrations to those used in (28), a very small amount of precipitation was observed. The protein remained in the solution and the protein concentration of the precipitation was close to zero. Incubating $\mathrm{CaCl}_{2}$ or $\mathrm{BaCl}_{2}$ with amounts of oleic acid alone that were similar to the amounts present in BAMLET produced similar precipitations as for BAMLET. The precipitation is assumed to be calcium or barium oleate. Incubating $\mathrm{CaCl}_{2}$ or $\mathrm{BaCl}_{2}$ with amounts of bovine $\alpha$-lactalbumin alone that were similar to the amounts present in BAMLET did not produce any cloudiness or precipitation.

\section{Calcium fluxes in human cells}

Introduction of thapsigargin inhibits the HAMLET-induced DNA fragmentation that is characteristic of HAMLET-induced cell death in A549 lung carcinoma cells (7). Thapsigargin causes an influx of calcium into the cytosol via plasma membrane store operated $\mathrm{Ca}^{2+}$ (SOC) channels when calcium diffuses out of the endoplasmic reticulum (99) due to inhibition by thapsigargin of the sarco/endoplasmic reticulum calcium ATPase (SERCA) transporters (100). HAMLET-induced cell death in the noncancerous immortalised MDCK cell line is inhibited by incubating with HAMLET in a calcium-free medium instead of a calciumcontaining medium (7). HAMLET triggers a rapid and sustained increase in intracellular $\left[\mathrm{Ca}^{2+}\right]$ in A549 cells, and the $\alpha$-lactalbumin protein alone or oleic acid alone does not (28). Co-incubation of HAMLET with phospholipase $\mathrm{C}$ inhibitor U73122 leads to cell death but does not increase intracellular $\left[\mathrm{Ca}^{2+}\right]$ (28). When phospholipase $\mathrm{C}$ is not inhibited it produces a signal that leads to the release of waves of calcium into the cytosol from the internal calcium stores of endoplasmic and sarcoplasmic reticulum $(101,102)$. U73122 may also or instead be an inhibitor of the sarcoplasmic reticulum $\mathrm{Ca}^{2+}$ pump that feeds the stores in the first place (102). The suppression of HAMLETinduced cytosolic $\mathrm{Ca}^{2+}$ flux by U73122 indicates that the $\mathrm{Ca}^{2+}$ flux came from the internal stores of endoplasmic and sarcoplasmic reticulum. Amiloride and $\mathrm{BaCl}_{2}$, inhibitors of $\mathrm{Na}^{+}$and $\mathrm{K}^{+}$ channels, also suppress the HAMLET-induced $\mathrm{Ca}^{2+}$ flux in addition to suppressing HAMLETinduced cell death (28). Introduction of ruthenium red, which inhibits mitochondrial uptake of $\mathrm{Ca}^{2+}$, affects sarcoplasmic reticulum uptake and release of $\mathrm{Ca}^{2+}$, and has effects on other $\mathrm{Ca}^{2+}$ and non$\mathrm{Ca}^{2+}$ channels and transporters $(103,104)$, reduces HAMLET-induced intracellular $\left[\mathrm{Ca}^{2+}\right]$ but has no effect on HAMLET-induced cell death in A549 cells (28).

A first interpretation of these results suggests that the ability of HAMLET to induce cell death is not correlated with the status or flux of calcium in the cell. Cell death occurs for HAMLET alone and for HAMLET plus U73122 and a cytosolic $\mathrm{Ca}^{2+}$ flux is observed for the former but not for the latter. The $\mathrm{Ca}^{2+}$ flux is observed for HAMLET plus thapsigargin treatment for which cell death is inhibited, and thus intracellular $\mathrm{Ca}^{2+}$ flux does not seem to be correlated with HAMLET-induced cell death or lack thereof.

Alternatively, interpreting these results with the generally accepted assumption that U73122 inhibits calcium store release into the cytosol, these results indicate that HAMLET-induced cell death activity requires the internal stores to contain calcium, as store depletion (due to thapsigargin or elimination of calcium from the medium) protects cells from HAMLET-induced cell death.

\section{Non-selective cation fluxes in human cells}

The multiple cation fluxes $\left(\mathrm{Na}^{+}, \mathrm{K}^{+}\right.$, and $\left.\mathrm{Ca}^{2+}\right)$ triggered by HAMLET (28) suggest that HAMLET may trigger a non-selective cation channel that allows the extracellular cations to flow down their gradient into the cell. Such a cation leak is expected to be cytotoxic to the cell.

\section{Calcium fluxes in plant cells}

The study model of ion channels in green algae Chara coralina cells is a convenient tool for the study of ion channels in humans because the $\mathrm{Ca}^{2+}$, $\mathrm{K}^{+}$, and $\mathrm{Ca}^{2+}$-dependent $\mathrm{Cl}^{-}$channels are analogous in structure and control mechanisms to those of many animal cells, and C. coralina cells 
conveniently are large and can grow in laboratory conditions (31). In $C$. coralina cells, HAMLET and oleic acid irreversibly decrease plasma membrane inward $\mathrm{Ca}^{2+}$ channel current, as does $\alpha$-lactalbumin alone but to a lesser extent (31). Extracellular oleic acid initially produces an increase in the $\mathrm{Ca}^{2+}$ current for around 5 minutes followed by a significant and reversible decrease (30). Increasing the oleic acid concentration induces an almost complete and irreversible suppression of the inward $\mathrm{Ca}^{2+}$ current (30). Introducing oleic acid intracellularly by perfusion reversibly suppresses the $\mathrm{Ca}^{2+}$ current, and increasing the oleic acid concentration then causes a reversible shift in the threshold voltage value at which a $\mathrm{Ca}^{2+}$ current appears (30). The changes in $\mathrm{Ca}^{2+}$ currents caused by HAMLET and oleic acid are thought to be due to effects on the $\mathrm{Ca}^{2+}$ ion channels, and the irreversible suppression of $\mathrm{Ca}^{2+}$ currents by higher concentrations of HAMLET and oleic acid may be due to structural damage to $\mathrm{Ca}^{2+}$ ion channels (30). Changes to $\mathrm{Ca}^{2+}$ channel threshold and inhibition of $\mathrm{Ca}^{2+}$-activated $\mathrm{Cl}^{-}$current, as is observed for HAMLET and oleic acid treatment, can also be caused by a $\mathrm{Ca}^{2+}$-chelating agent such as EGTA intracellularly $(30,105)$. Although they are not referred to as calcium chelators, the components of HAMLET are both known to associate with $\mathrm{Ca}^{2+}(106,107)$. These calcium current results obtained from treating green algae cells with HAMLET, do not follow the same pattern as the results from treating human cancer cells with HAMLET, but do show that HAMLET and its components affect and may even physically disrupt $\mathrm{Ca}^{2+}$ ion channels in the membrane.

\section{Chloride fluxes in plant cells}

The $\mathrm{Ca}^{2+}$-activated $\mathrm{Cl}^{-}$channel current results obtained from treating C. coralina cells with HAMLET or oleic acid, are basically the same for the $\mathrm{Ca}^{2+}$ ion channels, and may result from the HAMLET-induced events on $\mathrm{Ca}^{2+}$ ion channel currents making available $\mathrm{Ca}^{2+}$ ions to the $\mathrm{Ca}^{2+}$ activated $\mathrm{Cl}^{-}$channel rather than physical effects on the $\mathrm{Ca}^{2+}$-activated $\mathrm{Cl}^{-}$channel itself. HAMLET and oleic acid irreversibly decrease plasma membrane $\mathrm{Ca}^{2+}$-activated $\mathrm{Cl}^{-}$channel current, as does $\alpha$-lactalbumin alone but to a lesser extent (31). Extracellular oleic acid induces a reversible decrease in the $\mathrm{Ca}^{2+}$-activated $\mathrm{Cl}^{-}$current, and increasing the oleic acid concentration induces an almost complete and irreversible suppression of the current (30).

\section{Potassium fluxes in plant cells}

In $C$. coralina cells, HAMLET and oleic acid increase outward $\mathrm{K}^{+}$leakage current, and $\alpha$-lactalbumin alone does not (31). A high extracellular oleic acid concentration causes an increase in $\mathrm{K}^{+}$leakage (30). Perfusion of oleic acid into the cell does not affect the $\mathrm{K}^{+}$leakage (30). In this model, $\mathrm{K}^{+}$leakage, such as that observed for extracellular HAMLET, oleic acid, and $\alpha$-lactalbumin and not for intracellular oleic acid, is indicative of membrane lipid disruption (30).

\section{Calcium and sodium fluxes in bacterial cells}

The study of bacterial systems can yield insights into human systems because ion channels and transporters exist in bacteria that are homologous with human varieties. Bacterial genomes have significantly fewer genes and do not have the complexity of isoforms and regulation by noncoding DNA that is found in human genomes, making interpretation of observations more straightforward. A further motive for reasoning that HAMLET bacterial studies may shed light on HAMLET mechanisms in human cells is that human mitochondria are descendants of, and share similarities with, bacteria (33), and HAMLET exerts effects on isolated mitochondria (84).

HAMLET-like compounds are bactericidal to Streptococcus pneumoniae (17,32,35). Introduction of the $\mathrm{Ca}^{2+}$ transport inhibitor ruthenium red inhibits bacterial death, inhibits the intracellular $\left[\mathrm{Ca}^{2+}\right]$ increase, and inhibits the membrane depolarisation that HAMLET or ELOA normally induce in $S$. pneumoniae $(32,33)$. Introduction of $\mathrm{Na}^{+}$-channel inhibitors amiloride or 3',4'-dichlorobenzamil (DCB) inhibits membrane depolarisation, inhibits the intracellular $\left[\mathrm{Ca}^{2+}\right]$ increase, and reduces the bacterial death induced by HAMLET or ELOA treatment, and the effects are stronger when DCB (a more specific $\mathrm{Na}^{+} / \mathrm{Ca}^{2+}$ exchanger inhibitor) is used instead of amiloride (32,33). A consistently observed plateau in the middle of an otherwise steady linear increase of intracellular $\left[\mathrm{Ca}^{2+}\right]$ $(32,33)$ suggests that active transport of calcium is involved, as the plateau can be caused by 
precipitation of calcium with the inorganic phosphate resulting from ATP hydrolysis $(108,109)$. Decreasing the amount of extracellular $\mathrm{Na}^{+}$available increases intracellular $\left[\mathrm{Ca}^{2+}\right]$ and increases HAMLET-induced cell death (33). HAMLET also induces a decrease in intracellular $\left[\mathrm{K}^{+}\right]$in $S$. pneumoniae which is not considered significant because inhibiting this decrease in flux does not impact cell death (33). In the bacterium Staphylococcus aureus HAMLET dissipates the proton gradient, and this dissipation is not fully inhibited by the calcium channel inhibitor ruthenium red nor by the sodium channel inhibitor amiloride, indicating that another type of channel is involved in HAMLET-induced membrane depolarisation in this bacterium (36).

One interpretation of the $S$. pneumoniae results is that HAMLET-induced cell death in bacteria does not require membrane depolarisation and does require an increase in intracellular $\left[\mathrm{Ca}^{2+}\right]$ that is fed by $\mathrm{Na}^{+}$efflux. Another interpretation is that depolarisation is downstream of the initial dissipation of the proton gradient and inhibition of calcium fluxes does not block the upstream proton gradient dissipation.

\section{Disruption of membrane lipid organisation Binding to lipid membranes}

HAMLET binds zwitterionic small unilamellar vesicles (SUV) at $\mathrm{pH} 7.4$ and the amount of HAMLET that binds is nearly twice the amount of native $\alpha$-lactalbumin that binds the SUVs (31). When calcium is present, the amount of HAMLET that binds decreases to the same level as for $\alpha$-lactalbumin only (31). In light of the HAMLET-deactivating properties of calcium, this decrease is due to calcium stripping out the oleic acid from HAMLET and leaving protein only to bind the vesicle bilayer. At $\mathrm{pH}$ 7.0, HAMLET binds to the single bilayer of zwitterionic SUVs (110) and binds throughout the multiple layers of lipid membrane of zwitterionic multilamellar vesicles (110). HAMLET, and not $\alpha$-lactalbumin alone, binds negatively charged large unilamellar vesicles (LUV) at physiological pH $7.4(110,111)$. HAMLET binds these LUVs regardless of variations in their fluidity and 18:1 acyl chain content (110) and thus membrane 18:1 acyl content or fluidity are not the factors that determine the binding of HAMLET. ELOA, and not equine lysozyme alone, binds negativelycharged giant unilamellar vesicles (GUV) and makes them less rigid (76). In light of the HAMLET cargo offloading hypothesis, these membrane binding results suggest that when the oleic acid in HAMLET leaves HAMLET to associate with the cell membrane, the exposed positively charged $\alpha$-lactalbumin residues associating with the negatively charged membrane lipids augment the binding of the partially unfolded HAMLET protein and its exposed hydrophobic surfaces to the mainly hydrophobic lipid cell membrane.

When ELOA is first incubated with fat-free bovine serum albumin, which is expected to sequester all the oleate in ELOA, ELOA's interaction with membranes is abolished, indicating that the oleate in ELOA mediates the protein's interaction with membranes (76).

\section{Changes to morphology of lipid membranes}

BAMLET's effect on negatively-charged GUVs is membrane blebbing, with the blebs moving from the membrane to inside the vesicle, until the GUVs finally disappear (111). Oleic acid alone or $\alpha$-lactalbumin protein alone did not cause membrane blebbing (111). HAMLET, and not oleic acid alone, nor $\alpha$-lactalbumin alone nor an $\alpha$-lactalbumin mutant containing no cysteines, causes zwitterionic vesicles to change morphology from spherical to an elongated morphology deformed by greater flexibility of the thinner membrane at $\mathrm{pH} 7$ (110).

\section{Leakage of lipid membranes}

BAMLET causes leakage through the membrane of negatively-charged LUVs at pH $7.5(12,111)$. The amount of leakage increases when $\mathrm{pH}$ is 4.5 , and the amount of leakage decreases when $\mathrm{pH}$ is 9.1 (111). The membrane leakage is a function of the amount of oleate in the BAMLET compounds, with a high concentration of low-oleate BAMLET causing as much leakage as a lower concentration of high-oleate BAMLET (111). Oleic acid alone or $\alpha$-lactalbumin protein alone do not cause membrane leakage of those GUVs (111). HAMLET, and not $\alpha$-lactalbumin alone nor oleic acid alone, causes leakage from negatively charged LUVs at pH 7.4 (110). HAMLET does not cause leakage from zwitterionic LUVs at $\mathrm{pH}$ 7.4, but does cause leakage at $\mathrm{pH} 5.0$ (110). However, ELOA does not cause leakage from negatively-charged GUVs and LUVs (76). 


\section{Binding at cell membranes}

Both HAMLET and $\alpha$-lactalbumin alone bind the HAMLET-sensitive A549 human lung carcinoma and L1210 mouse leukaemia cells and HAMLETinsensitive human renal tubular epithelial cells (HRTEC) cells, and this binding is visible by microscopy after 10 minutes and is maximal by 30 minutes (37). The binding is distributed in patches separated by areas of membrane where HAMLET does not bind (37). More total HAMLET binds than total $\alpha$-lactalbumin alone (37). ELOA accumulates in high concentration at the cell membrane of PC12 (rat pheochromocytoma) cancer cell membranes in a non-uniform distribution, until the cell membrane ruptures and ELOA swiftly flows into the cell, filling the interior within half a minute $(49,85)$.

The non-uniform distribution of HAMLET and ELOA bound to cell membranes suggests that they are associating with specific regions in the cell membrane, such as membrane proteins, lipid rafts or non-lipid raft domains.

\section{Leakage through cancer cell membranes}

Plasma membrane vesicles (PMV) can be prepared from cancer cells and contain the membrane lipids and membrane proteins of the cancer cells and are significantly smaller than the cancer cell (112), with an increased membrane curvature. HAMLET binds PMVs from PC12 (rat pheochromocytoma) and A549 cancer cells (110) in a non-uniform manner, indicating that certain regions of the membrane have higher affinity for HAMLET (110). The PMV morphology changes from round to elongated shapes in response to HAMLET (110). Oleic acid alone also binds in a non-uniform manner, and does not induce conformational change of the PMV, indicating that oleic acid incorporates into PMV membranes without disrupting the structure (110).

\section{Passes through cellular membranes}

The protein component of HAMLET translocates across cellular membranes into the cytoplasm $(4,16,18,37,49,59)$ and later accumulates in the nucleus (37). One hypothesis is that the oleate, having a higher affinity for the cell membrane, dissociates from the protein. After the oleate has dissociated from the protein, the protein is left in an unfolded state with exposed hydrophobic surfaces that have high affinity for cell membranes and thus the unfolded state of the protein facilitates its translocation across the lipid membrane. Contributing to this hypothesis is the evidence reviewed above concerning HAMLET binding the multiple lipid membrane layers of multilamellar vesicles (110) and causing blebbing of homogenous phospholipid membranes (111). Also contributing to this hypothesis is the evidence that oleic acid increases the flexibility of membranes and conformational freedom of the lipids in the membrane $(113,114)$. Unfortunately, the enlightening experiment of tracking oleic acid introduced to a cell, either alone or in a HAMLET-like compound, to determine whether it remains in the membrane or enters the cell with or separately from the protein, has not yet been conducted.

ELOA, however, does not cross PC12 rat pheochromocytoma cell membranes, and instead accumulates on the cell membrane until it lyses the cell membrane and ELOA then flows into the cell (49). Upon incubation with bacteria, ELOA regains some of the native enzymatic activity of the protein component lysozyme (76). This is attributed to some of the lysozyme protein component refolding to a native-like bactericidal conformation after it has released the oleate cargo to the bacterial membrane (76). These results of ELOA lysozyme protein appearing to refold and observed to not enter the cell, support the hypothesis that it is the unfolded state of HAMLET proteins that facilitates their entry into cells by hydrophobic interaction with the cell membrane.

\section{INTRACELLULAR TARGETS DNA fragmentation and caspases activation of classical apoptosis}

After HAMLET treatment, classic apoptosis cell death characteristics are observed: nuclear condensation, cell shrinkage, cytoplasmic blebbing, and DNA fragmentation (7,16,37,57). The loss of cell viability of A549 human lung carcinoma and L1210 mouse leukaemia cells upon exposure to HAMLET is accompanied by apoptosis-associated DNA fragmentation (37).

In human leukaemia Jurkat cells, caspase-3 activity increases 10-fold 3 hours after HAMLET treatment, and in A549 it increases 7-fold 2 hours after treatment (56). Caspase-6 transiently increases $40 \%$ at 2 hours in Jurkat and increases to $55 \%$ at 4 hours in A549 after HAMLET treatment (56). 


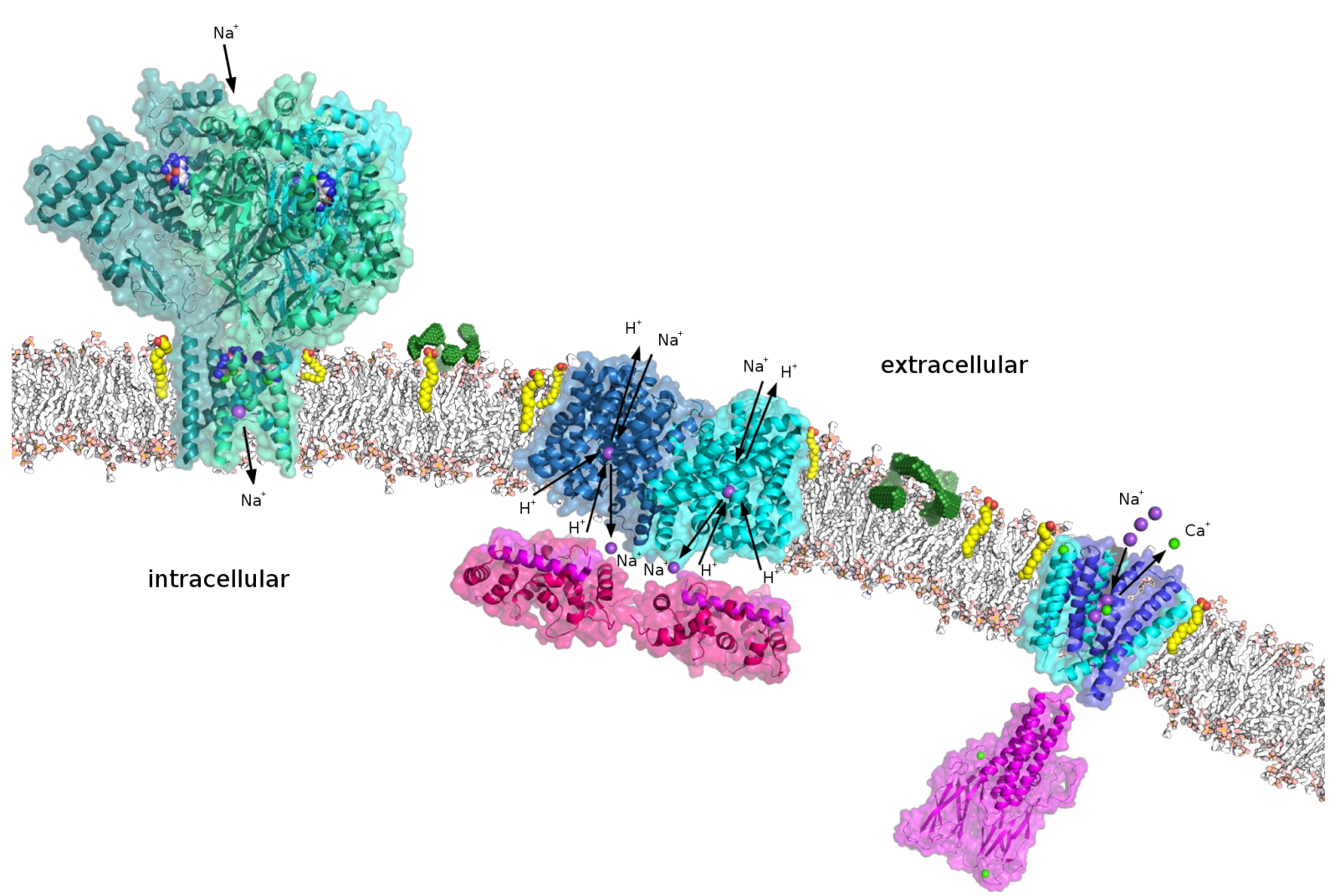

Figure 4. The hypothesised interactions of HAMLET components with the cell membrane and indirectly with some key membrane proteins. The oleic acid (yellow with red balls) has dissociated from the protein of HAMLET (dark green) (6) and is associating with the lipid membrane (grey and pink) potentially making the membrane more fluid, and also affecting lipid packing around the membrane protein channels. The membrane proteins are an epithelial sodium channel (PDBID:4NTX (115), left), a Na ${ }^{+} \mathrm{H}^{+}$exchanger (PDBID:4CZA (116) and PDB ID:2BEC (117), central), and a $\mathrm{Na}^{+} / \mathrm{Ca}^{2+}$ exchanger (PDB ID:3V5U (118), PDB ID:1H6G (119), PDB ID:2FWS (120), and PDB ID:2FWU, arranged according to (121), right).

Co-treatment with the caspase inhibitor zVADfmk increases cell viability and inhibits the DNA fragmentation (56). The PARP, lamin B, and $\alpha$ fodrin cleavage targets of caspases are cleaved in Jurkat, and PARP and lamin B are cleaved in A549, in response to HAMLET treatment, and zVAD-fmk inhibited some of this cleavage (56). The Fas cell surface death receptor is not activated by HAMLET, as an antagonistic antiCD95 receptor antibody, ZB4, does not affect the HAMLET-induced caspase- 3 activity (56). The activation of caspase- 3 coincides with the release of cytochrome $\mathrm{c}$ from the mitochondria into the cytosol (56). However, adding HAMLET to cytosolic extracts does not activate caspase-3
(56). This suggests that HAMLET does not directly activate caspases.

In human leukaemia Jurkat cells and A549 human lung adenocarcinoma cells, HAMLET treatment induces an increase in caspase-2, caspase-3 and caspase-9, but the levels are significantly lower than the response of these cells to the chemotherapy compound etoposide (21). HAMLET induces a 4.8 -fold increase in phosphatidyl serine (PS) exposure, which is reduced by the pan-caspase inhibitor zVAD-fmk, whereas etoposide induces an 11.2-fold increase (21). In Jurkat human leukaemia cells, use of the pan-caspase inhibitor zVAD-fmk reduces HAMLET-induced cell death $\mathrm{LD}_{50}$ from $20 \mu \mathrm{M}$ to 
$17 \mu \mathrm{M}$ (21). In A549 human lung adenocarcinoma cells, use of the pan-caspase inhibitor zVAD-fmk reduces HAMLET-induced cell death $\mathrm{LD}_{50}$ from $46 \mu \mathrm{M}$ to $41 \mu \mathrm{M}(21)$. These results indicate that apoptosis-like cell death is triggered in response to HAMLET and may be enough to kill the cell. However, this mechanism does not explain all aspects of cell death that are observed, and thus other mechanisms are driving the HAMLETinduced cell death.

In U87MG human glioma cells, HAMLET treatment leads to activation of caspase- 8 followed by apoptotic cell death as indicated by TUNEL assay, regulated mostly by caspase- 8 and caspase-9 (38). The caspase- 8 inhibitor reduces HAMLET-induced cell death by the same amount as does the pan-caspase inhibitor zVAD-fmk, which suggests that caspase- 8 is the main type of caspase regulating apoptosis in U87MG cells (38).

BAMLET induces dose-dependent condensation of chromatin and shrinkage of cells, hallmarks of apoptosis-like cell death, in MCF7 human breast adenocarcinoma, even though these cells do not express caspase-3 (16). When transfected with caspase- 3 , these cells exhibited caspase-3 activity in response to BAMLET, but the sensitivity to BAMLET did not change and inhibition of caspases by zVAD-fmk did not change the sensitivity (16). Again, these results indicate that apoptosis-like cell death is triggered in response to HAMLET, but that other mechanisms are ultimately driving the cell death.

Jurkat cells treated with HAMLET exhibit chromatin condensation into small spheres, large spheres and crescents, which are chromatin changes associated with apoptosis (21). HAMLET treatment also induces marginalisation of chromatin to the nuclear periphery (21). Cotreatment with the caspases inhibitor zVAD-fmk leads to a decrease in the apoptosis-like chromatin changes and an increase in the chromatin marginalisation changes (21). These results show that HAMLET induces chromatin condensation in a caspase-dependent and a caspase-independent manner, and blocking caspases shifts the chromatin response to the caspase-independent pathway (21).

These results suggest that HAMLET triggers a low level of apoptosis-like cell death, but the cell death mechanisms do not rely solely on activation of caspases.
Cells having classic apoptosis-resistance mechanisms

The p53 tumour-suppressor gene is defective in over $50 \%$ of cancers, particularly at relapse (122). There is no difference in or inhibition of HAMLET-induced cell death in HCT116 human colorectal carcinoma cells having a homozygous p53 deletion compared to those having the wild type p53 gene (21). HAMLET is equally effective in killing H1299 human lung carcinoma cells having homozygous p53 deletion and H1299 dominant-negative His175 gain of function mutant that is even more resistant to apoptosis (21).

The Bcl-2 family of proteins regulates cellular commitment to apoptosis and overexpression of pro-survival $\mathrm{Bcl}-2$ is associated with cancers (123). HAMLET treatment of K562 human myelogenous leukaemia cells transfected such that they overexpress $\mathrm{Bcl}-2$ does not affect Bcl-2 expression levels and does not affect or inhibit cell death (21). HAMLET treatment of Jurkat human leukaemia cells transfected such that they overexpress Bcl-2 does not affect caspase-3 response and does not affect or inhibit cell death (21).

The Bcl-xl protein is one of the pro-survival Bcl-2 family members (123). HAMLET treatment of F15.12 immortalised non-cancerous mouse proB-cell lymphocytic cells transfected such that they overexpress Bcl-xl does not affect or inhibit cell death (21). HAMLET treatment of A498 human kidney carcinoma cells transfected such that they overexpress $\mathrm{Bcl}-\mathrm{xl}$ does not affect or inhibit cell death (21).

These results show that HAMLET is effective in killing cancer cells that possess the antiapoptosis mechanisms of decreased expression of the p53 tumour-suppressor gene, increased Bcl-2 anti-apoptosis expression, or increased $\mathrm{Bcl}-\mathrm{xl}$ anti-apoptosis expression.

\section{Autophagy}

Autophagy, the mechanism of degradation of cellular proteins and components through the action of autophagosomes and lysosomes, is involved with cell survival during times of starvation and is considered to be part of orderly autophagic cell death programs (124-127).

In A549 human lung carcinoma cells, knockdown by interference RNA of Beclin-1, a protein involved in autophagosome formation, 
reduces HAMLET-induced cell death to $45 \%$ whereas it is $70 \%$ for control cells (128). Knockdown of Atg5, another protein involved in autophagosome formation, reduces HAMLETinduced cell death to $46 \%$ compared to $70 \%$ for controls (128). Various indicators of the occurrence of autophagy are observed in HAMLET-treated A549 cells, including a granular cytosolic pattern of LC3-II, LC3-II flux visible when its degradation is inhibited; a decrease in the phosphorylation of the autophagy inhibitor mTOR and of an mTOR substrate p70 S6K; an increase in protein levels of Beclin-1; and increases in mRNA levels of Beclin-1, Atg5 and $\operatorname{Atg} 7$ (128). When the apoptosis caspase inhibitor zVAD-fmk is used in conjunction with Beclin-1 knockdown, there is no additional reduction in HAMLET-induced cell death (128). These results are evidence that A549 human lung carcinoma cells undergo autophagy before dying in response to HAMLET treatment. As is usually the case with autophagic cell death $(126,127)$, these results demonstrate that autophagy is present in HAMLET-treated A549 cells but do not demonstrate that the causative mechanism of cell death is autophagy.

In U87MG human glioma cells treated with HAMLET, a granular cytosolic LC3-II flux is seen along with an increase in $\mathrm{p} 62$, a protein involved with autophagosome development (and also involved in cross-talk with the proteasome system (129)), and the p62 protein co-localises with the LC3-II, suggesting that the cells are carrying out autophagy in response to HAMLET (38). HAMLET treatment plus activation of autophagy by rapamycin treatment leads to an increase in cell viability and decrease in p62 levels (38). HAMLET treatment plus activation of autophagy with starvation leads to a decrease in cell viability and increase in p62 levels (38). HAMLET treatment plus knockdown of autophagy protein Atg5 leads to a decrease in cell viability and increase in p62 levels (38). These results suggest that autophagy has a protective role in stress conditions and HAMLET-induced cell death, and when the stress is too much for survival then the autophagy process becomes exhausted and autophagy proteins accumulate because they are no longer being processed (38).

Knockdown of p62 reduces the sensitivity of U87MG cells to HAMLET treatment, and overexpression of p62 increases the HAMLET cytotoxicity (38). When the C-terminus of p62 is truncated, U87MG cells are more resistant to HAMLET-induced cell death, with cell viability increasing to $80 \%$ from the $65 \%$ for controls (38). These results suggest that HAMLET-induced autophagy processes are contributing to cell death in U87MG cells because disabling a part of the autophagy system reduces HAMLET-induced cell death.

\section{Lysosomal cell death program}

BAMLET treatment of MCF7 human breast adenocarcinoma cells and U2OS human bone osteosarcoma cells results in BAMLET colocalising with acidic endolysosomal organelles, permeabilisation of the lysosomal membrane, release of cathepsin L into the cytosol, then activation of the pro-apoptotic Bax protein (16). This cell death program is not delayed by the protease inhibitor zFA-fmk (16). In MCF7 cells, expression of proteins that stabilise lysosomes, HSP70, HSP70-2 and lens epithelium-derived growth factor, decrease the BAMLET-induced cell death. It is thought that BAMLET-induced cell death involves lysosomal membrane permeabilisation that leads to the release of many cytotoxic lysosomal hydrolases whose effects cannot be inhibited by inhibiting cysteine cathepsin activity (16).

\section{Necrotic cell death}

In A549 human lung carcinoma cells, HAMLET treatment causes up to $10 \%$ of the cells to undergo necrosis, with the cells showing ruptured plasma membranes, loss of cellular material, and merging of nuclear and cytoplasmic content (128). THP1 human monocytic leukaemia cells undergo a necrotic-like cell death in response to HAMLET treatment (13).

\section{Localisation with nuclei and binding of histones}

After entering A549 human lung carcinoma cells, L1210 mouse leukaemia cells, or non-cancerous human renal tubular epithelial cells, ${ }^{125}$ I-labelled, biotinylated or fluorescently-labelled HAMLET protein is first seen evenly distributed throughout the cytoplasm (37). In the cancer cells, the bulk of labeled HAMLET protein localises to the nuclei, which does not occur for the non-cancerous cells $(37,57)$. The uptake of HAMLET protein into the nucleus is inhibited by wheat-germ agglutinin 
(WGA), which inhibits transport through the nuclear pore (37). HAMLET protein binds strongly to histone $\mathrm{H} 3$, and weakly to histones $\mathrm{H} 2 \mathrm{~B}$ and $\mathrm{H} 4$, and binds both natively folded and denatured forms of histones (57). Bovine $\alpha$-lactalbumin protein, without oleic acid, binds isolated histones (130), demonstrating that it is not necessary for oleic acid to be bound to the HAMLET or BAMLET protein component for that protein to bind histones.

\section{Mitochondrial association and mitochondrial permeability transition in isolated mitochondria}

In Jurkat human leukaemia cells, cytoplasmic HAMLET co-localises with mitochondria (56).

In A549 human lung carcinoma cells, HAMLET treatment causes mitochondria to become swollen with disrupted membranes and loss of cristae organisation (128). Adding HAMLET to $\mathrm{Ca}^{2+}$ loaded isolated rat liver mitochondria induces swelling and the release from the mitochondrial intermembrane space of adenylate kinase- 2 and cytochrome c (84), whose release is an event in classic apoptosis upstream of caspases activation. The calcium chelator EGTA prevents the HAMLET-induced swelling and protein release, as does ruthenium red (84), which interacts with various proteins including the mitochondrial $\mathrm{Ca}^{2+}$ uniporter (131) and thus blocks uptake of calcium into mitochondria, which inhibits permeability transition of the mitochondria which is an apoptosis activation pathway. This indicates that calcium is required for the HAMLET-induced swelling effect. The HAMLET-induced swelling and protein release is inhibited by the mitochondrial permeability transition (MPT) pore inhibitors cyclosporin A or ubiquinone 0 (84). This indicates that HAMLET-induced swelling and release of apoptosis-associated protein in isolated mitochondria involves opening of the MPT pore. Adding HAMLET to $\mathrm{Ca}^{2+}$-loaded isolated mitochondria causes a biphasic decrease in mitochondrial membrane potential - a first and fast phase followed by a larger long phase that ends in complete loss of mitochondrial membrane potential (84). Adding cyclosporin A or ATP, which can also inhibit the MPT pore, does not block the first phase and does block the second phase (84). This suggests that the second phase of mitochondrial membrane potential loss is due to the MPT, and the first phase is due to HAMLET inducing a proton leak by some other means. Adding oleic acid, dissolved and thus solubilised in ethanol, to the $\mathrm{Ca}^{2+}$-loaded isolated mitochondria induces the first phase mitochondrial membrane potential decrease but does not induce the second phase of mitochondrial membrane potential collapse (84). This indicates that the HAMLET-induced second phase mitochondrial membrane potential collapse is not due to the oleate in HAMLET and that oleic acid does not open the MPT pore. Adding bovine serum albumin delays the mitochondrial swelling and delays the dissipation of the mitochondrial potential (84). This indicates either that it is not the oleic acid in HAMLET that causes these effects, or that it is the oleic acid and BSA only partially deactivates HAMLET.

\section{Mild proton leak in isolated mitochondria}

When isolated mitochondria are in state 4 respiration due to the depletion of ADP, increasing HAMLET or increasing oleic acid leads to an increase in state 4 respiration and a decrease in the respiratory control ratio, and this mild mitochondrial uncoupling occurs even in the absence of $\mathrm{Ca}^{2+}$ and in the presence of cyclosporin A (84). This indicates that the oleic acid in HAMLET enhances the proton permeability of the inner mitochondrial membrane by a mechanism other than the MPT.

\section{Interaction with proteasomes}

Confocal microscopy of A549 human lung carcinoma cells shows that in the cell membrane region, there is $65 \%$ co-localisation of HAMLET with the $20 \mathrm{~S}$ core proteasomes, and in the cytosolic region the co-localisation is $64 \%$ (18). Incubation of HAMLET with isolated 20S proteasomes induces an initial 10 minutes burst of proteasome activity followed by a partial inhibition that results in the proteasomes processing at approximately half their maximal rate (18). In A549 cells treated with HAMLET, proteasome activity steadily decreases to around half its initial rate by 6 hours (18). After 1 hour incubation with HAMLET in A549 cells, an increase in proteasome antibody staining is observed, suggesting that some proteasomes have undergone degradation (18). SDS-PAGE provides evidence that after 20 minutes incubation with HAMLET, isolated proteasomes undergo some autoproteolysis of the proteasome (18). These 
results suggest that HAMLET is recognised by the 20S proteasomes and either resists degradation (18); is activated by a low concentration of HAMLET's oleic acid (132) leading to self-proteolysis of the proteasome (18); is deactivated by higher concentrations of HAMLET's oleic acid (132); or else orderly degradation of HAMLET protein by the proteasome is interrupted by HAMLET-triggered cell death program events elsewhere in the cell that affect the proteasome system.

\section{Interaction with $\alpha$-actinin}

HAMLET treatment of A549 human lung carcinoma cells results in HAMLET binding $\alpha$ actinin proteins (58), which are spectrin proteins involved in cytoskeletal scaffolding (133). HAMLET binds several places on the $\alpha$-actinin proteins (58). Knockdown of $\alpha$-actinin gene expression does not change HAMLET-induced cell death of suspended A549 cells and results in more pronounced HAMLET-induced cell morphology changes as the cells undergo cell death (58). This indicates that the binding of HAMLET to actinins is not the initiating cell death mechanism, and may be an example of unfolded protein binding cellular proteins indiscriminately.

\section{Binding to nucleotide-binding proteins}

Co-immunoprecipitation studies show that HAMLET protein binds to over 400 out of 8,000 human proteins on a protein microarray, and $35 \%$ of the proteins that the protein component of HAMLET binds are nucleotide-binding ATPases and GTPase, including kinases that are involved with cellular signalling via phosphorylation of their targets (134).

\section{Interaction with ATP synthase}

ATP synthase in the mitochondria, also known as complex V, is the molecular complex responsible for generating most of the ATP energy molecules in healthy cells (using the proton gradient produced by mitochondrial complexes I, III, and IV to drive a molecular motor that creates ATP from ADP and inorganic phosphate). HAMLET protein interacts with the soluble F1 catalytic head of ATP synthase (59), and after HAMLET treatment, cellular ATP levels decrease and rotation of the ATP synthase motor is no longer detected (59). In the HAMLET ATP synthase study, adherent A549 human lung carcinoma cells manifest a punctate pattern of ATP synthase subunits alpha and beta throughout the cytosol (59) which is the part of the cell where mitochondria are found. After HAMLET treatment and the cell has started dying, subunit beta co-localises with HAMLET protein in the cytosol, and subunit alpha co-localises with HAMLET protein in a few large aggregates in the cytosol (59).

Subunits alpha and beta are bound together in the intact F1 component of ATP synthase, and their divergent paths upon HAMLET treatment that results in cell death indicates that the ATP synthase subunits are no longer bound together in an intact ATP synthase F1 component. Their divergent paths after HAMLET treatment that initiates cell death may also indicate that these subunits have roles in cell death regulation. Indeed, ATP synthase subunit beta has been linked to Bcl-xl which is involved in apoptosis regulation (135). Subunit beta is also involved in calcium signalling at the plasma and intracellular membranes of developing muscle cells (136). As the main cytotoxic component of HAMLET is the oleic acid rather than the protein, the binding of HAMLET protein to ATP synthase protein subunits is likely a result of the unfolded HAMLET protein, no longer partially folded around its oleic acid cargo, binding to the ATP synthase subunits that are in proximity to HAMLET and are themselves now dissociated. Mutations in ATP synthase subunits are associated with some cancers (137-139).

ATP synthase can also be found on the plasma membrane in some cell types, located in lipid rafts (140), with the F1 soluble head extracellular (141). Plasma membrane ATP synthase subunit beta is involved in stimulating angiogenesis in endothelial cells, and inhibiting it via binding of angiostatin or anti-beta-subunit antibodies inhibits endothelial cell proliferation (142-144). Plasma membrane ATP synthase generates ATP as part of shear stress management in pulmonary artery endothelial cells $(145,146)$, umbilical vein endothelial cells (147), and lymphatic endothelial cells (148). Ectopic ATP synthase is involved in HDL uptake and transport in aortic endothelial cells (149). In hepatocytes, plasma membrane ATP synthase subunit beta is involved in endocytosis of HDL as part of cholesterol management (150). In keratinocytes, ectopic ATP 
synthase releases ATP as part of wound healing (151). Ectopic ATP synthase is present in antigenpresenting cells (152), neurons (153), colon cells (154), rat tonsils (155), and in the immortalised mouse embryonic fibroblast cell line NIH-3T3 (140). Ectopic ATP synthase is not found in erythrocytes and lymphocytes (156).

Ectopic ATP synthase on the plasma membrane has been reported for some cancer cell types: K562 leukaemia (156), A549 lung carcinoma $(156,157)$, Raji Burkitt lymphoma (156), HepG2 hepatocellular carcinoma (150), Jurkat leukaemia (158), osteosarcoma (159), neuroblastoma (153), $\mathrm{CaCo} 2$ colorectal adenocarcinoma (154), HeLa ovarian carcinoma (160), breast cancer specimens (161), pheochromocytoma (162), and paraganglioma (162). Ectopic ATP synthase on tumour cells is involved in a mechanism by which a class of $\mathrm{T}$ lymphocytes recognises the tumour cells $(163,164)$. Inhibition of ATP generation by plasma membrane ATP synthase is currently under investigation as a target of anti-cancer drugs for lung cancer $(157,165,166)$, breast cancer (161,167-169), colon cancer (154), urinary bladder carcinoma (170), pheochromocytoma (162), and paraganglioma (162). In a lung adenocarcinoma study, the ATP synthase complex and the beta subunit were found to be present in the plasma membrane of A549 and CL1-0 lung cancer cells in flow cytometry experiments (157). The other members of the oxidative phosphorylation electron transport chain complexes I, II, III, and IV - in addition to complex V, were also found to be present in the plasma membrane in Western blot experiments (157). Treatment with the ATP synthase inhibitor citreoviridin leads to accumulation of reactive oxygen species and cell death (157). This indicates that plasma membrane ATP synthase is involved in managing the intracellular acidification caused by glycolysis in those cancer cells by allowing the protons generated by glycolysis to run down their gradient and out of the cell so that the cytosol does not remain acidic. As the protons run down their gradient, the ATP synthase molecular motor is operated and ATP is generated.

It is not yet understood how ATP synthase arrives at the plasma membrane $(171,172)$. In hepatocytes (160) and HepG2 hepatocellular carcinoma (173), the plasma membrane ATP synthase appears to be assembled in and transported from the mitochondria. In $\mathrm{HeLa}$ ovarian carcinoma cells, cholesterol loading causes translocation of subunit beta from the mitochondria to the cell surface (174). In neurons, deficiency of palmitoyl protein thioesterase 1 is linked to an increase in ectopic F1 (175).

\section{Lysing of red blood cells}

BAMLET exposure of 10 minutes induces a change in morphology of erythrocytes, with the disc shaped cells becoming cup shaped or displaying blebs or angular projections on the surface (29). Longer incubations of BAMLET or other HAMLET-like compounds causes haemolysis of erythrocytes $(5,13,29,44)$ and this type of erythrocyte cell death is called eryptosis (29). At $4^{\circ} \mathrm{C}$ BAMLET does not lyse erythrocytes, (29). Although BAMLET-exposed erythrocytes display the classic apoptosis characteristic of phosphatidyl serine exposure on the outside of the cell membrane, caspases inhibitors and thiol proteases do not restrict the BAMLET-induced haemolysis (29). Amiloride, $\mathrm{BaCl}_{2}$, or the calcium ionophore A23187, reduce the BAMLET-induced haemolysis (29), which suggests that ion fluxes or calcium are required for BAMLET-induced haemolysis of red blood cells. The intracellular calcium levels of erythrocytes do not rise after BAMLET treatment and pre-loading the cells with calcium does not change the level of BAMLET induced lysis (29), which leads to the interpretation that calcium is not involved in the BAMLET-induced lysis of erythrocytes. Inclusion of $\mathrm{CaCl}_{2}$ during incubation of erythrocytes with BAMLET inhibits the lysis (29), and given that calcium deactivates BAMLET, this is due to the deactivation of BAMLET by calcium rather than due to the involvement of calcium fluxes in erythrocyte cell death.

The BAMLET-induced cup shape morphology of erythrocytes looks similar to their cup shape form when travelling through very small blood vessels (176). The cup shaped morphology is caused by shear forces $(176,177)$. Reorganisation of cytoskeletal spectrin is involved in the formation of the cup shape morphology when erythrocytes are subject to shear forces (178). As HAMLET has been shown to interact with $\alpha$-actinin, a type of spectrin protein, the HAMLET-induced deformation of erythrocytes may be due to HAMLET protein 
interaction with $\alpha$-actinin in the cytoskeleton.

Oleic acid causes reversible morphological changes to red blood cells, from an irregularly contoured disk, to a flat cell with spicules on the surface, to a spherical cell with spicules on the surface, as oleic acid concentration is increased (179). At higher concentrations, oleic acid and fatty acids cause haemolysis (179-181). At low concentrations oleic acid actually protects red blood cells from osmotic rupture and this is thought to be due to binding of the fatty acid to the membrane or a membrane protein (180). Oleic acid and other amphipathic anions mimic the action of calmodulin in activating the red blood cell plasma membrane $\mathrm{Ca}^{2+}$ pump ATPase (182). This activated efflux of calcium may be how low concentrations of oleic acid protect red blood cells from osmotic rupture. The red blood cell plasma membrane $\mathrm{Ca}^{2+}$ pump ATPase contains a central pore similar to the calcium pump of sarcoplasmic reticulum $(183,184)$. This pump is very sensitive to the phospholipid environment (185-187) due to its autoinhibition domain binding being disrupted by particular lipids, thus activating the pump (187). Removal of autoinhibition of the $\mathrm{Ca}^{2+}$ pump ATPase leading to outflow of calcium may be part of the mechanism of how higher concentrations of oleic acid lead to haemolysis. The $\mathrm{Na}^{+} / \mathrm{Ca}^{2+}$ exchanger is a more powerful $\mathrm{Ca}^{2+}$ extrusion system and thus has a more significant effect on global cytosolic calcium levels than does the $\mathrm{Ca}^{2+}$ pump ATPase (187). However, current thinking is that the $\mathrm{Ca}^{2+}$ pump ATPase may have significant effects on calcium levels and signalling in microdomains of the red blood cell that in turn affect nearby proteins that have the ability to make larger global effects (187). Given that oleic acid can bind and activate the $\mathrm{Ca}^{2+}$ pump ATPase (182), this pump may be involved in BAMLET's oleic acid induced haemolysis in the presence of ATP, even though global erythrocyte calcium levels do not change in response to BAMLET (29).

That calcium is able to delay or prevent the haemolysis that occurs in red blood cells when they are placed in a hypotonic solution of nonelectrolytes such as dextrose or lactose has long been known (188). Membranes are less leaky in the presence of calcium because calcium exerts stabilising effects on the structural and functional properties of biomembranes (189). Calcium is adsorbed onto the phospholipid cell membrane and stabilises the membrane into an ordered and less fluid state $(189,190)$. The oleic acid induced lysis of red blood cells may be due to an increase in membrane fluidity caused by insertion of oleic acid into the membrane $(191,192)$. The oleic acidinduced lysis of red blood cells may be due to an interaction between oleic acid and calcium that results in less calcium available to bind and stabilise the membrane. Figure 20 shows that erythrocytes are significantly more sensitive to BAMLET when incubated in a calcium-free medium (5) than when calcium is present (44). These results may indicate that calcium is an important factor in BAMLET-induced and oleic acid-induced lysis of erythrocytes. Erythrocytes do not have the internal mechanisms for sequestering and controlling intracellular levels of calcium possessed by other types of cells (189) which simplifies the analysis of the BAMLETinduced cell death. If disruption of calcium membrane binding is the mechanism by which BAMLET induces cell death in erythrocytes, this may indicate that the same mechanism is the root cause of BAMLET-induced cell death in other types of cells that possess more sophisticated mechanisms for controlling the fluctuations of calcium in its environment. Epithelial cells lose their integrity and become detached from one another in calcium-deficient media (189).

\section{Inhibition of BAMLET by ectopic protein chaperones}

Ectopic expression of heat shock protein HSP70-2 protein in MCF7 human breast adenocarcinoma cells or of HSP70 protein in mouse fibrosarcoma inhibits around 20 to $40 \%$ of the BAMLETinduced cell death normally experienced by these cells (16). In MCF7 cells, ectopic expression of lens epithelium-derived growth factor (LEDGF), a protein that may upregulate heat shock proteins (193), inhibits around $50 \%$ of the BAMLETinduced cell death (16). The HSP70 family of protein chaperones bind the exposed hydrophobic surfaces of soluble proteins such as proteins that are being translated and thus not yet folded $(194,195)$, and are also able to bind fatty acids (196-198). It is plausible that HSP70 disables BAMLET by binding the oleic acid. 


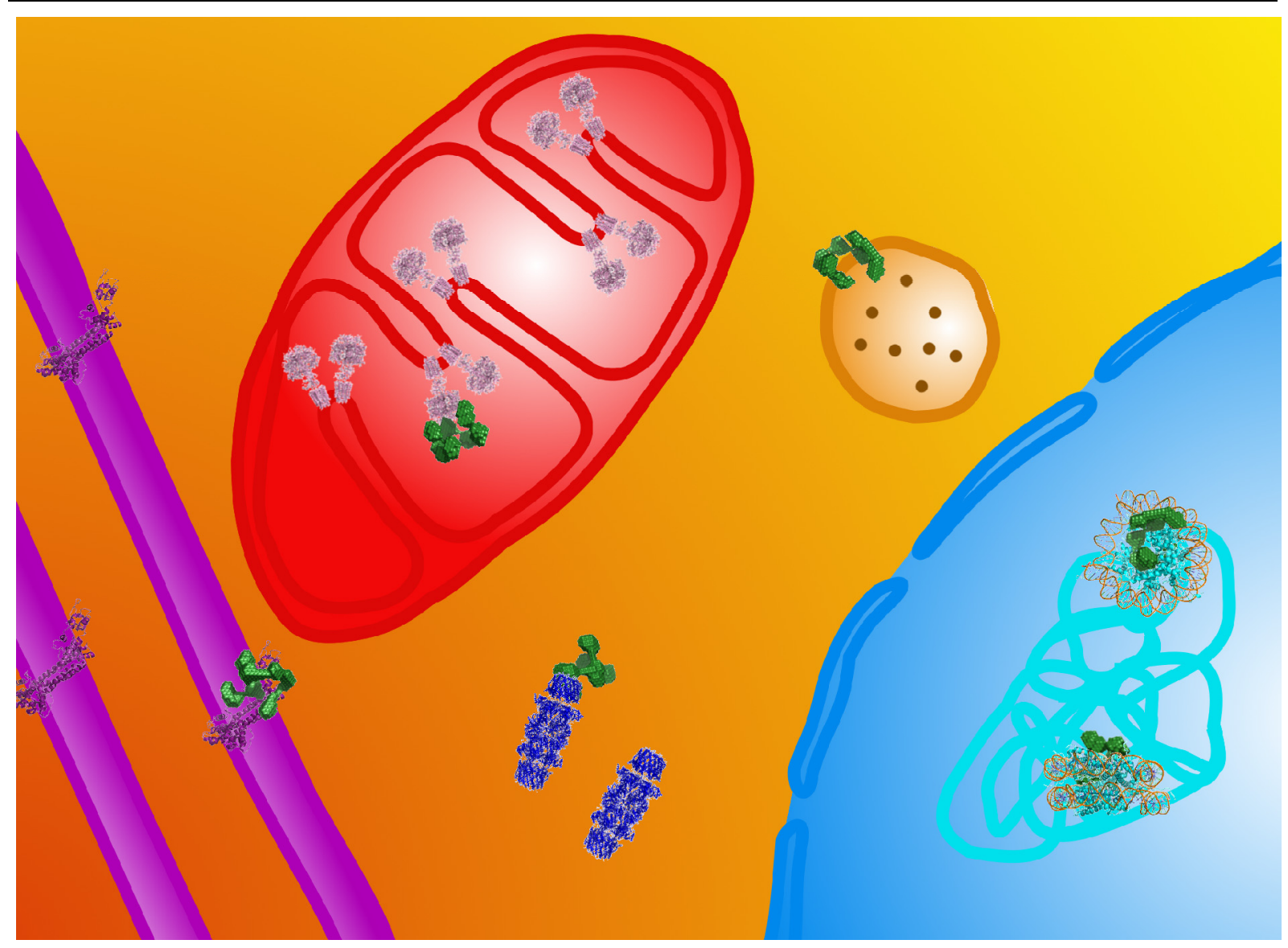

Figure 5. Potential intracellular targets of HAMLET, not drawn to scale. BAMLET protein (dark green) (6) is shown binding histones (cyan protein with orange DNA wrapped around it) (PDBID:1AOI (278)) in the nucleus (light blue), proteasomes (dark blue) (PDBID:1FNT (202)), lysosome membranes (brown), $\alpha$-actinin (the purple cross-bars connecting purple spectrin rods) (modified from PDBID:4D1E (203)), and ATP synthase (pink) (PDBID:2XOK (204)) in the mitochondrion (red).

This indicates that the anticipated resistance mechanisms that cancer cells would evolve in response to treatment with HAMLET-like compounds is upregulation of heat shock proteins outside the cell membrane, to bind the active fatty acid ingredient and deactivate HAMLET.

\section{Phagocytosis-like particles}

Although not explicitly reported, published images show that HAMLET, presumably unfolded after having offloaded its oleic acid cargo, forms concentrated round particles inside the cell (Figure 8B in (4), Figure $3 \mathrm{C}$ in (28), Figure $2 \mathrm{~B}$ in (59), Figure 6B in (134)) that are reminiscent of the particles of phagocytosis, such as when the epithelial cells A549 human lung carcinoma carry out phagocytosis of Escherichia coli bacteria (Figure 4 in (199)). Phagocytosis is the ingestion by cells of large particles $\geq 0.5 \mu \mathrm{m}$ diameter, such as bacteria, apoptotic bodies and debris (200). The 227 to $292 \mathrm{~nm}$ diameter of BAMLET (22) is of the same order of magnitude as the $0.7-1.0 \mu \mathrm{m}$ diameter of $E$. coli (201).

\section{ARE HAMLET-LIKE COMPOUNDS FORMED IN NATURE?}

The components of HAMLET (free fatty acid and undigested and digested protein) and the conditions for creating HAMLET (mixing of components at low $\mathrm{pH}$ or even at higher $\mathrm{pH}$ ) exist in the digestive tract of adults and infants when they drink milk. $\alpha$-Lactalbumin is generally the 
most abundant protein in human milk, making up 39 to $60 \%$ of the whey protein depending on weeks post-partum (205-207). Oleic acid is the most common fatty acid in human milk and $98 \%$ is in triglyceride form (208). In bovine milk, around $73 \%$ of whey protein and $10 \%$ of total protein is $\beta$-lactoglobulin, and around $27 \%$ of whey protein and $5 \%$ of total protein is $\alpha$-lactalbumin (209). Around $23 \%$ of the fatty acids in bovine milk fat triacylglycerols is oleic acid (210). In the stomach and small intestine, the triacylglycerols in milk globules undergo sequential lipolysis by lipases to release the free fatty acids such as oleic acid (208,211). HAMLET-like compounds can be made from the intact $\alpha$-lactalbumin and $\beta$-lactoglobulin proteins or from digested protein fragments $(1,7,8,53,54)$. HAMLET-like compounds can be made by mixing the components, and lowering $\mathrm{pH}$ to 3 promotes unfolding of the protein which assists in the creation of HAMLET-like compounds $(53,65)$. The gastric $\mathrm{pH}$ of adults before drinking or eating is around $\mathrm{pH} 2$ and rises to $\mathrm{pH} 5$ to 7 after drinking a protein drink (212). The gastric $\mathrm{pH}$ of infants before drinking is around $\mathrm{pH} 2$, and frequent feeding means that the gastric $\mathrm{pH}$ is often at pH 4 and above (213).

A study using a mixture of calcium and bovine $\alpha$-lactalbumin (both found in milk) and oleic acid dissolved in ethanol, subjected to simulated gastric conditions of $\mathrm{pH} 2.5$ then raised to $\mathrm{pH} \mathrm{7,demonstrated} \mathrm{that} \mathrm{a} \mathrm{cytotoxic} \mathrm{compound}$ with the same structural characteristics as BAMLET is formed (214).

A capsule endoscopy study sampling the gastric contents of adults drinking a water-based mixture containing bovine $\alpha$-lactalbumin, sucrose, and oleic acid dissolved in ethanol, found that the protein unfolds but the gastric contents after drinking this drink are not able to kill cancer cells in vitro (212). A cytotoxic HAMLET-like compound was not produced in the stomach from drinking this mixture and it is concluded that the mixing of components that took place in the stomach was not adequate for the formation of BAMLET (212). However, unlike the drink used in the capsule endoscopy study, milk is a complicated system where milk fats and stomach bile salts interact to form longer lasting fat globules and other structures (211). The structures may even provide a surface where $\alpha$-lactalbumin may interact with oleic acid as it comes off the triglycerides similar to the formation of
HAMLET on a chromatography column. Thus it is not possible to exclude that HAMLET-like complexes are formed in the stomach when milk is ingested.

A qualitative retrospective study of 20 cancer patients who drank human milk as a complementary or alternative therapy reported that patients or their proxies found that human milk consumption did not change their disease outcome (215). The patients appear to have received a psychological benefit from the possibility of hope from this unproven therapy (215). Some patients drank raw human milk. However, other patients drank human milk that was pasteurised rather than fresh, which may affect milk lipase activity in hydrolysing triglycerides to release free fatty acid and may affect $\alpha$-lactalbumin function.

A study in mice predisposed to colon cancer, who received HAMLET orally (26) suggests that HAMLET, or oleic acid alone in solubilised form, may survive into the colon to exert an anti-tumour effect.

Studies and meta-analyses of studies looking for links between being breastfed as an infant and incidence of childhood cancers find a very weak decrease in occurrence of leukaemia, Hodgkin's disease, neuroblastoma, and non-haematological cancers, and wonder whether the weak association is due to confounding factors rather than being a true association (216-219). A 65-year follow-up study found no correlation between being breastfed as an infant and occurrence of cancer in adulthood (217).

\section{DISCUSSION}

It is often pointed out that cancer is really over 200 different diseases, with each cancer displaying unique characteristics and adaptations to selective pressure. HAMLET has broadspectrum activity against over 50 cancer cells lines. As 16 possible membrane and intracellular targets (Figure 5) have been identified by distinct experiments and over 400 protein targets have been identified by microarray experiments, it is possible that HAMLET targets different cancer types by different mechanisms. Another explanation for HAMLET's broad-spectrum anticancer activity is that the oleic acid of HAMLET, with its potential effects on membrane lipids, membrane protein lipid packing, and signalling, is toxic to all cells without there being a cancer- 
specific HAMLET target. However, the resistance to HAMLET of 9 of the 10 non-blood noncancerous primary cell cultures treated at levels that killed cancer cell lines argues for extensive specificity for cancer cells over broad-spectrum toxicity to all cells. The simplest explanation for HAMLET's ability to kill cancer cells, though certainly not yet proven, is that HAMLET targets features present in all cancer cells that are representative of cancer cells. If this is the case, then the fact that HAMLET kills immortalised cell lines that generally form benign or short-lived tumours in vivo (220-223) and are generally classified as non-cancerous and neoplastic, at the same range of doses as it kills cancer cell lines (Figure 2), indicates that the proposed HAMLET target is one of the early characteristics that a cell acquires in the process of becoming cancerous. Just as the over 200 different types of cancers all have the characteristic of more frequent cell division with the consequent exposure of DNA, the characteristic exploited by the most successful DNA-intercalation chemotherapies of the last 40 years, pin-pointing the HAMLET target may be tantamount to pin-pointing a new cancer target that is shared by the over 200 different types of cancers. And just as there are non-cancerous cells that divide frequently, leading to toxicities induced by the DNA-intercalation chemotherapies, the HAMLET target will be a feature of some non-cancerous cells and thus HAMLET treatment may involve some HAMLET-related toxicities that will need to be managed. The in vivo HAMLET experiments and trials to date, however, have demonstrated no toxic side effects $(14,23-27)$.

The mechanism employed by HAMLET-like compounds to initiate cell death of cancer cells is not yet clear. Inhibition of ion fluxes over the cell membrane appears to significantly inhibit HAMLET's cytotoxicity, whereas inhibition of intracellular HAMLET targets does not lead to strong inhibition of HAMLET-induced cell death. It is likely that the initiating HAMLET-induced cell death mechanism involves changes in permeability to ions through cancer cell membrane proteins. If the active ingredient of HAMLET-like compounds is the oleic acid lipid, as is now generally accepted, it is quite plausible that the initiating damage by HAMLET to cancer cells is a biophysical effect involving membrane lipids or lipids associated with membrane embedded protein rather than an effect involving highly evolutionarily-crafted biological components consisting of specific binding of signalling molecules to receptors. A more general biophysical interaction between lipid species is expected to be a more robustly enduring interaction in the face of the constant and creative evolution of cancer cells, and would explain how HAMLET's mode of action is broad spectrum. Many intracellular targets of HAMLET invoking multiple types of cell death have been identified, and these may be downstream effects from a cell death mechanism actually initiated earlier at the plasma membrane. Once HAMLET has damaged a cell's permeability to ions and therefore control of ion trafficking, programmed cell death would be triggered in those cancer cells that retain functioning cell death mechanisms, and necrosis would be triggered in those having diminished or damaged cell death mechanisms, leading to cell death nonetheless. Based on the process by which the HAMLET complexes are formed, more or less oleic acid lipid is present and the level of oleic acid present may determine which primary activation mechanism is triggered by the cell.

Once HAMLET has offloaded its oleate cargo at a cell membrane, what remains is the unfolded protein polypeptide component of HAMLET that passes to the inside of the cell. Once in the cytosol, the unfolded protein of HAMLET has been shown to bind to many other intracellular components, and this may additionally adversely affect cellular health and result in supplementation of the other cell death activities already underway. An excess of unfolded protein inside the cell activates the unfolded protein response (UPR), and when the presence of unfolded protein causes persistent endoplasmic reticulum stress, the UPR induces apoptotic cell death (279). Unfolded HAMLET protein inside the cell may trigger cell death by this UPR mechanism.

The picture that has emerged from structural studies is that HAMLET-like compounds consist of a novel structure of partially-unfolded protein having free fatty acid associated in non-specific binding sites in the protein's hydrophobic interior. The biological anti-cancer activity may be due to the semi-stability of such a structure. When the compound encounters a cancer cell membrane, the oleate may leave the complex and preferentially associate with the lipid membrane due to a higher biophysical attraction between a free lipid, not associated with a lipid micelle, and 
a lipid membrane, than that between a lipid and a mainly hydrophobic protein interior.

Most studies on cancer cell membrane fluidity find that cancer cells are significantly softer than normal cells, which facilitates the cancer cell's invasion of surrounding tissue, intraand extravasation into lymphatic and blood vessels, and metastasis (224-232). Membrane elasticity may be the selective cancer cell and red blood cell characteristic that HAMLET targets. The oleic acid of HAMLET may increase the fluidity $(191,192)$ to a level that compromises the membrane's impermeability to ions. The softer cancer cell membrane may be the characteristic that allows entry of HAMLET protein into the cell.

One of the possible HAMLET targets under important consideration because it may represent a specific characteristic of all cancer cells, is the ATP synthase complex that was recently reported to be involved in HAMLET-induced cell death (59). ATP synthase has recently been identified as likely to be the elusive main component of the mitochondrial permeability transition pore (MPTP) (233-239) that is an upstream initiator of programmed cell death (234). One of the proposals is that the centre of the c-subunit ring of the F0 membrane component forms the pore (233). Cancer cells would need to reduce or eliminate ATP synthase from the mitochondria, so that the deregulated state of the mitochondria would not trigger programmed cell death via opening of the MPTP, leading to a need for cancer cells to produce ATP by alternative means. ATP synthase activity is downregulated in cancer $(240,241)$ and its inhibitory factor is upregulated (242). Two alternative means of generating ATP are the upregulation of glycolysis, which is a well-known feature of cancers (243-245), and rerouting ATP synthase to the plasma cell membrane and nuclear membrane to generate ATP there instead of in the mitochondrial inner membrane. The oleate from HAMLET may be localising within a lipid plug in the centre of the ATP synthase c-ring, and then being precipitated by calcium, carrying the lipid plug with it, and evacuating a hole - the MPTP - in the plasma cell membrane. This hypothesised mechanism would require intracellular calcium to be present, and the original HAMLET study found an indication that the presence of intracellular calcium is required for the HAMLET anti-cancer effect (7). The lipid plug may consist of cardiolipin, as cardiolipin is associated with ATP synthase (246) and is localised in the c-ring centre "hole" of the V-type ATPase molecular motor (247) that is structurally similar to ATP synthase. Precipitation of the plug by excess calcium and phosphate may be the usual MPTP trigger in mitochondria of noncancer cells. The ease with which oleate could approach the ATP synthase c-ring centre extracellularly may depend on the state of the regulation of the connection/disconnection of the F1 soluble head to the F0 membrane component, as the F1 soluble head is found extracellularly in ectopic ATP synthase (141). This working hypothesis can indicate which non-cancer cells will be sensitive to HAMLET (endothelial cells, keratinocytes, and embryonic fibroblast NIH-3T3 have ectopic ATP synthase and were sensitive to HAMLET with $\mathrm{LD}_{50}$ doses determined in the same range as $\mathrm{LD}_{50}$ doses for cancer cell lines, Figure 2). This hypothesis relative to the ATP synthase does not explain the sensitivity of erythrocytes to HAMLET, which are particularly sensitive to oleic acid due to other factors discussed in the section on haemolysis of red blood cells. That the HAMLET anti-cancer target may be a mitochondrial cell death triggering pore, in the form of ATP synthase, located in the plasma membrane of cancer cells, is a highly speculative but intriguing working hypothesis for HAMLET's broad spectrum anti-cancer activity.

Alternatively, oleic acid may be generally toxic to all cells rather than being more specifically toxic to only cancer cells. Membrane proteins are sensitive to the fluidity of the membrane (248) and oleic acid increases membrane fluidity $(191,192)$. The signalling of oleic acid and free fatty acids has been extensively reported (249-258) and oleic acid signalling could be involved in oleic acid induced cell death. Initial deleterious effects of HAMLET might involve specific signals of evolutionarilycrafted biological components. Oleic acid alone $(179-181)$ and HAMLET $(5,13,29,44)$ are toxic to erythrocytes, causing haemolysis, and the synthesis of available evidence is that the erythrocyte plasma membrane $\mathrm{Ca}^{2+}$ pump ATPase is the target, as the signalling emanating from this pump is known to be sensitive to oleic acid (185). These pumps are ubiquitous in eukaryote cells (259) and may prove to be a significant HAMLET and oleate target in all cells, cancerous and noncancerous.

The mainstay of current anti-cancer 
chemotherapies is small molecule drugs. A common chemotherapy-resistance mechanism employed by cancers is the multi-drug efflux pumps that recognise many different molecules as being foreign and pumps them out of the cancer cell (260). It is thought that resistance to chemotherapy causes treatment failure in over $90 \%$ of patients with metastatic cancer (261). HAMLET compounds are protein-based and their size dictates that they will not be pumped out of cancer cells by multi-drug efflux pumps. At $\sim 110$ $\mathrm{kDa}$ (51), BAMLET is of a similar size to drug efflux pumps themselves, such as the $170 \mathrm{kDa} \mathrm{P}$ glycoprotein (262), whereas the pump removes small molecule drugs from $330 \mathrm{Da}$ to $4 \mathrm{kDa}$ (263). Specifically, one of the most potent anticancer therapies is the $300 \mathrm{Da}$ cisplatin, and drug efflux pumping is one of the main mechanisms for cancer resistance to cisplatin (264). Although the mechanism employed by HAMLET to kill cells is not well-understood, it is already clear that HAMLET's mechanism for killing cancer cells is a new type of anti-cancer mechanism not employed by currently available anti-cancer chemotherapies. Although the cell death mechanisms of HAMLET-like compounds are not yet unambiguously understood, the evidence is that HAMLET-like compounds represent a novel type of protein-lipid structure and make use of a new type of cell death mechanism having broad-spectrum anti-cancer activity and a significant although not exclusive selectivity for cancer cells versus healthy, differentiated cells. Thus, we anticipate that HAMLET will be effective in killing cancer cells that have developed resistance to currently available chemotherapies. The cytotoxicity to cancer cells of HAMLET-like compounds may prove to be synergistic with existing anti-cancer therapies, enabling the use of lower doses of the latter, resulting in lower toxicities, and ultimately making it more difficult for a cancer cell to simultaneously possess resistance to the two different cell death mechanisms of both HAMLET and existing anti-cancer therapies. Indeed, preliminary studies indicate that treatment of cancer cells with fatty acid is synergistic with radiation therapy $(265,266)$, and it is very clear that BAMLET is a fatty acid treatment $(4,17,51,53)$. Thus, BAMLET treatment in combination with radiation therapy may prove to be more effective in treating tumours than radiation therapy alone.
Immunotherapies are currently emerging as successful anti-cancer therapies (267). HAMLET appears to work equally well as an anti-cancer therapy in immunocompromised patients and animals as for immunocompetent subjects $(18,25,27)$. Cancer chemotherapy treatments and cancer itself suppress parts of the immune system (268-271). Immunocompromised transplant recipient patients, who have a higher incidence of cancer than the rest of the immunocompetent population (272), might not be able to benefit from the emerging immunotherapies due to immunotherapy-triggered increased risk of organ rejection (273) or of acquiring a deadly infection $(274,275)$, or due to decreased immunotherapy effectiveness resulting from the immunosuppression (276). HAMLET's ability to be effective without requiring immunocompetence may turn out to be an important factor in clinical success.

One immediate task for the HAMLET field is to continue developing delivery systems that avoid HAMLET-like compounds being deactivated in blood and enhance delivery directly to cancer cells. As the HAMLET mode of action involves the oleate having higher affinity for cell membranes once it comes into contact, HAMLET will probably not transit intact through healthy tissue in order to reach cancer cells. The in vivo experiments already carried out involved direct delivery of HAMLET to the bladder (by urinary tract catheter) $(14,23,24)$, brain (by intracranial infusion) (25), skin (as a topical cream for warts) (27), and upper respiratory tract instillation (32). These are all creative examples of direct delivery of HAMLET-like compounds to tumours without HAMLET exposure to blood. Now that we have good understanding of the structure of HAMLETlike compounds $(5,6)$, it is possible to carry out rational drug design to develop delivery systems for the HAMLET-like compounds that conserve their structure, which is crucial as it is the basis for their anti-cancer activity, whilst avoiding problem deactivation by blood. The understanding of structure will also guide the choice of compatible delivery vehicles that can attach, incorporate, and accommodate a semistable compound of the size of HAMLET protein. A goal of HAMLET delivery vehicles would be to enable HAMLET to be injected into the blood stream, or to be ingested as a pill such that HAMLET survives digestion in the stomach to end up in the blood stream, thereby reaching the 
tumour sites around the body. Although HAMLET is toxic to blood cells and to a lesser extent endothelial cells in vitro, it is anticipated that any small amounts of HAMLET that might inadvertently find its way into the blood stream will be deactivated by the calcium and albumin in blood. A large amount of HAMLET in the blood or in proximity to sensitive endothelial cells would overcome the blood's capacity to deactivate HAMLET. If there is a risk of this leading to toxicities, then HAMLET-like compounds will need to be administered in many small doses or administered slowly, so that the blood's protective effects against HAMLET toxicity is not overwhelmed, similar to how widely used cisplatin chemotherapy is administered to cancer patients over hours so as to avoid cisplatin toxicity caused by overwhelming the kidneys (277).

The other immediate continuing task for HAMLET researchers is to determine the HAMLET target, because the available in vitro and in vivo evidence is that this target is a characteristic of all cancers and could be the basis of a new generation of broad-spectrum anticancer therapies. Identifying the HAMLET target would permit rational drug design efforts to design new compounds having the same target, perhaps small soluble molecules that do not have HAMLET's problem of being deactivated in blood.

We look forward to the continuing research developments - developments in identifying the HAMLET cell death mechanism(s) and developments in clinical anti-cancer applications - concerning this intriguing family of compounds composed of various proteins, including the most common human milk protein, and the most common human milk fatty acid.

\section{ACKNOWLEDGEMENTS}

The authors thank Bryan Kim for the lovely lipid membrane graphic. The authors are grateful to Yuen Yee Cheng, Glen Reid, Ruby Liu, Kadir Sarun, and Marissa Williams of ADRI, Ryan Middleton, Richard Banati, and Geetanjali Dhand of ANSTO, Viive Howell, Amanda Hudson and Chris Weir of Kolling Institute, and Gayan Jayawickrama of University of Sydney. The authors wish to thank members of their respective research groups for a supportive environment and their collegiality, in particular Peter Holden, Rob
Russell, Natalia Davydova, Agata Rekas, Karyn Wilde, Marie Gillon and Hayley Barker. The study was funded by the Medical Research Council, Sweden (Grant number: K2015-99X22872-01-6) awarded to APH. This work was supported by an Australian Postgraduate Award (EMR). WBC wishes to acknowledge support from the Rebecca L. Cooper Medical Research Foundation.

\section{REFERENCES}

1. Svensson M, Håkansson A, Mossberg AK, Linse S, Svanborg C. Conversion of alpha-lactalbumin to a protein inducing apoptosis. Proc Natl Acad Sci U S A. 2000;97(8):4221-6.

2. Zhang M, Yang F Jr, Yang F, Chen J, Zheng CY, Liang Y. Cytotoxic aggregates of alpha-lactalbumin induced by unsaturated fatty acid induce apoptosis in tumor cells. Chem Biol Interact. 2009;180(2):131-42.

3. Fang B, Zhang M, Tian M, Ren FZ. Selfassembled $\beta$-lactoglobulin-oleic acid and $\beta$-lactoglobulin-linoleic acid complexes with antitumor activities. J Dairy Sci. 2015;98(5):2898-907.

4. Lišková K, Auty MAE, Chaurin V, Min S, Mok HK, O'Brien N, Kelly LA, Brodkorb A. Cytotoxic complexes of sodium oleate with $\beta$-lactoglobulin. Eur J Lipid Sci Technol. 2011;113:1207-18.

5. Kaspersen JD, Pedersen JN, Hansted JG, Nielsen SB, Sakthivel S, Wilhelm K, Nemashkalova EL, Permyakov SE, Permyakov EA, Pinto Oliveira CL, Morozova-Roche LA, Otzen DE, Pedersen JS. Generic structures of cytotoxic liprotides: nano-sized complexes with oleic acid cores and shells of disordered proteins. Chembiochem. 2014;15(18):2693-702.

6. Rath EM, Duff AP, Håkansson AP, Knott RB, Church WB. Small-angle X-ray scattering of BAMLET at $\mathrm{pH} 12$ : a complex of $\alpha$-lactalbumin and oleic acid. Proteins. 2014;82(7):1400-8.

7. Håkansson A, Zhivotovsky B, Orrenius S, Sabharwal H, Svanborg C. (1995) Apoptosis induced by a human milk protein. Proc Natl Acad Sci U S A. 1995;92(17):8064-8.

8. Svensson M, Fast J, Mossberg AK, Düringer C, Gustafsson L, Hallgren O, Brooks CL, Berliner L, Linse S, Svanborg C. Alpha-lactalbumin unfolding is not sufficient to cause apoptosis, but is required for the conversion to HAMLET (human alpha-lactalbumin made lethal to tumor cells). Protein Sci. 2003;12(12):2794-804.

9. Knyazeva EL, Grishchenko VM, Fadeev RS, Akatov VS, Permyakov SE, Permyakov EA. 
Who is Mr. HAMLET? Interaction of human alpha-lactalbumin with monomeric oleic acid. Biochemistry. 2008;47(49):13127-37.

10. Kamijima T, Ohmura A, Sato T, Akimoto K, Itabashi M, Mizuguchi M, Kamiya M, Kikukawa T, Aizawa T, Takahashi M, Kawano K, Demura M. Heat-treatment method for producing fatty acid-bound alpha-lactalbumin that induces tumor cell death. Biochem Biophys Res Commun. 2008;376(1):211-4.

11. Permyakov SE, Knyazeva EL, Leonteva MV, Fadeev RS, Chekanov AV, Zhadan AP, Håkansson AP, Akatov VS, Permyakov EA. A novel method for preparation of HAMLET-like protein complexes. Biochimie. 2011;93(9):1495-501.

12. Wen H, Rundgren IM, Glomm WR, Halskau Ø. Benchmarking Different BAMLET-like Preparations With Respect to Tryptophan Exposure, Interfacial Activity, and Effect on Cell Viability. J Bioanal Biomed. 2011;S5:003.

13. Brinkmann CR, Heegaard CW, Petersen TE, Jensenius JC, Thiel S. The toxicity of bovine $\alpha$-lactalbumin made lethal to tumor cells is highly dependent on oleic acid and induces killing in cancer cell lines and noncancerderived primary cells. FEBS J. 2011;278(11):1955-67.

14. Xiao Z, Mak A, Koch K, Moore RB. A molecular complex of bovine milk protein and oleic acid selectively kills cancer cells in vitro and inhibits tumour growth in an orthotopic rat bladder tumour model. BJU Int 2013;112(2):E201-10.

15. Fang B, Zhang M, Jiang L, Jing H, Ren FZ. Influence of $\mathrm{pH}$ on the structure and oleic acid binding ability of bovine $\alpha$-lactalbumin. Protein J. 2012;31(7):564-72.

16. Rammer P, Groth-Pedersen L, Kirkegaard T, Daugaard M, Rytter A, Szyniarowski P, HøyerHansen M, Povlsen LK, Nylandsted J, Larsen JE, Jäättelä M. BAMLET activates a lysosomal cell death program in cancer cells. Mol Cancer Ther. 2010;9(1):24-32.

17. Permyakov SE, Knyazeva EL, Khasanova LM, Fadeev RS, Zhadan AP, Roche-Hakansson H, Håkansson AP, Akatov VS, Permyakov EA. Oleic acid is a key cytotoxic component of HAMLET-like complexes. Biol Chem. 2012;393(1-2):85-92.

18. Gustafsson L, Aits S, Onnerfjord P, Trulsson M, Storm P, Svanborg C. Changes in proteasome structure and function caused by HAMLET in tumor cells. PLoS One. 2009;4(4):e5229.

19. Atri MS, Saboury AA, Moosavi-Movahedi AA, Goliaei B, Sefidbakht Y, Alijanvand $\mathrm{HH}$, Sharifzadeh A, Niasari-Naslaji A. Structure and stability analysis of cytotoxic complex of camel $\alpha$-lactalbumin and unsaturated fatty acids produced at high temperature. J Biomol Struct Dyn. 2011;28(6):919-28.

20. Lišková K, Kelly AL, O'Brien N, Brodkorb A. Effect of denaturation of alpha-lactalbumin on the formation of BAMLET (bovine alpha-lactalbumin made lethal to tumor cells). J Agric Food Chem. 2010;58(7):4421-7.

21. Hallgren O, Gustafsson L, Irjala H, Selivanova G, Orrenius S, Svanborg C. HAMLET triggers apoptosis but tumor cell death is independent of caspases, Bcl-2 and p53. Apoptosis. 2006 ;11(2):221-33.

22. Delgado Y, Morales-Cruz M, Figueroa CM, Hernández-Román J, Hernández G, Griebenow $\mathrm{K}$. The cytotoxicity of BAMLET complexes is due to oleic acid and independent of the $\alpha$-lactalbumin component. FEBS Open Bio. 2015 May 4;5:397-404.

23. Mossberg AK, Wullt B, Gustafsson L, Månsson W, Ljunggren E, Svanborg C. Bladder cancers respond to intravesical instillation of HAMLET (human alpha-lactalbumin made lethal to tumor cells). Int J Cancer. 2007;121(6):1352-9.

24. Mossberg AK, Hou Y, Svensson M, Holmqvist B, Svanborg C. HAMLET treatment delays bladder cancer development. J Urol. 2010;183(4):1590-7.

25. Fischer W, Gustafsson L, Mossberg AK, Gronli J, Mork S, Bjerkvig R, Svanborg C. Human alpha-lactalbumin made lethal to tumor cells (HAMLET) kills human glioblastoma cells in brain xenografts by an apoptosis-like mechanism and prolongs survival. Cancer Res. 2004;64(6):2105-12.

26. Puthia M, Storm P, Nadeem A, Hsiung S, Svanborg C. Prevention and treatment of colon cancer by peroral administration of HAMLET (human $\alpha$-lactalbumin made lethal to tumour cells). Gut. 2014;63(1):131-42.

27. Gustafsson L, Leijonhufvud I, Aronsson A, Mossberg AK, Svanborg C. Treatment of skin papillomas with topical alpha-lactalbumin-oleic acid. N Engl J Med. 2004;350(26):2663-72.

28. Storm P, Klausen TK, Trulsson M, Ho C S J, Dosnon M, Westergren T, Chao Y, Rydström A, Yang H, Pedersen SF, Svanborg C. A unifying mechanism for cancer cell death through ion channel activation by HAMLET. PLoS One. 2013;8(3):e58578.

29. Hoque M, Nanduri R, Gupta J, Mahajan S, Gupta P, Saleemuddin M. Oleic acid complex of bovine $\alpha$-lactalbumin induces eryptosis in human and other erythrocytes by a $\mathrm{Ca} 2+-$ independent mechanism. Biochim Biophys Acta. 2015 Apr 22. pii: S0304-4165(15)001142.

30. Kataev A, Zherelova OM, Grishchenko VM. 


\begin{abstract}
Effects of oleic acid on ionic channels of plasma membranes of green alga Chara corallina. Biochemistry (Moscow) Supplement Series A: Membrane and Cell Biology. 2013;7(2):141-47.

31. Zherelova OM, Kataev AA, Grishchenko VM, Knyazeva EL, Permyakov SE, Permyakov EA. Interaction of antitumor alpha-lactalbumin-oleic acid complexes with artificial and natural membranes. J Bioenerg Biomembr. 2009;41(3):229-37.
\end{abstract}

32. Clementi EA, Wilhelm KR, Schleucher J, Morozova-Roche LA, Hakansson AP. A complex of equine lysozyme and oleic acid with bactericidal activity against Streptococcus pneumoniae. PLoS One. 2013;8(11):e80649.

33. Clementi EA, Marks LR, Duffey ME, Hakansson AP. A novel initiation mechanism of death in Streptococcus pneumoniae induced by the human milk protein-lipid complex HAMLET and activated during physiological death. J Biol Chem. 2012;287(32):27168-82.

34. Brinkmann CR, Thiel S, Larsen MK, Petersen TE, Jensenius JC, Heegaard CW. Preparation and comparison of cytotoxic complexes formed between oleic acid and either bovine or human $\alpha$-lactalbumin. J Dairy Sci. 2011;94(5):2159-70.

35. Håkansson $\mathrm{A}$, Svensson $\mathrm{M}$, Mossberg $\mathrm{AK}$, Sabharwal H, Linse S, Lazou I, Lönnerdal B, Svanborg C. A folding variant of alpha-lactalbumin with bactericidal activity against Streptococcus pneumoniae. Mol Microbiol. 2000;35(3):589-600.

36. Marks LR, Clementi EA, Hakansson AP. Sensitization of Staphylococcus aureus to methicillin and other antibiotics in vitro and in vivo in the presence of HAMLET. PLoS One. 2013;8(5):e63158.

37. Håkansson A, Andréasson J, Zhivotovsky B, Karpman D, Orrenius S, Svanborg C. Multimeric alpha-lactalbumin from human milk induces apoptosis through a direct effect on cell nuclei. Exp Cell Res. 1999;246(2):451-60.

38. Zhang YB, Gong JL, Xing TY, Zheng SP, Ding W. Autophagy protein p62/SQSTM1 is involved in HAMLET-induced cell death by modulating apotosis in U87MG cells. Cell Death Dis. 2013 Mar 21;4:e550.

39. Svanborg C, Agerstam H, Aronson A, Bjerkvig $\mathrm{R}$, Düringer $\mathrm{C}$, Fischer $\mathrm{W}$, Gustafsson L, Hallgren O, Leijonhuvud I, Linse S, Mossberg AK, Nilsson $\mathrm{H}$, Pettersson J, Svensson M. HAMLET kills tumor cells by an apoptosis-like mechanism--cellular, molecular, and therapeutic aspects. Adv Cancer Res. 2003;88:1-29.

40. Jögi A, Vaapil M, Johansson M, Påhlman S. Cancer cell differentiation heterogeneity and aggressive behavior in solid tumors. Ups J Med Sci. 2012 May;117(2):217-24.
41. Maitland NJ, Collins AT. Cancer stem cells - A therapeutic target? Curr Opin Mol Ther. 2010 Dec;12(6):662-73.

42. Ben-Porath I, Thomson MW, Carey VJ, Ge R, Bell GW, Regev A, Weinberg RA. An embryonic stem cell-like gene expression signature in poorly differentiated aggressive human tumors. Nat Genet. 2008 May;40(5):499507.

43. Tang C, Ang BT, Pervaiz S. Cancer stem cell: target for anti-cancer therapy. FASEB J. 2007 Dec;21(14):3777-85.

44. Hoque M, Dave S, Gupta P, Saleemuddin M. Oleic acid may be the key contributor in the BAMLET-induced erythrocyte hemolysis and tumoricidal action. PLoS One. 2013;8(9):e68390.

45. Storm P, Aits S, Puthia MK, Urbano A, Northen T, Powers S, Bowen B, Chao Y, Reindl W, Lee DY, Sullivan NL, Zhang J, Trulsson M, Yang H, Watson JD, Svanborg C. Conserved features of cancer cells define their sensitivity to HAMLET-induced death; c-Myc and glycolysis. Oncogene. 2011;30(48):4765-79.

46. Pettersson J, Mossberg AK, Svanborg C. Alpha-lactalbumin species variation, HAMLET formation, and tumor cell death. Biochem Biophys Res Commun. 2006;345(1):260-70.

47. Nakamura T, Aizawa T, Kariya R, Okada S, Demura M, Kawano K, Makabe K, Kuwajima K. Molecular mechanisms of the cytotoxicity of human $\alpha$-lactalbumin made lethal to tumor cells (HAMLET) and other protein-oleic acid complexes. J Biol Chem. 2013;288(20):1440816.

48. Fang B, Zhang M, Tian M, Jiang L, Guo HY, Ren FZ. Bovine lactoferrin binds oleic acid to form an anti-tumor complex similar to HAMLET. Biochim Biophys Acta. 2014;1841(4):535-43.

49. Wilhelm K, Darinskas A, Noppe W, Duchardt E, Mok KH, Vukojević V, Schleucher J, Morozova-Roche LA. Protein oligomerization induced by oleic acid at the solid-liquid interface--equine lysozyme cytotoxic complexes. FEBS J. 2009;276(15):3975-89.

50. Pinato O, Spolaore B, Canton M, Polverino de Laureto P, Fontana A. The interaction of apomyoglobin with oleic acid leads to a protein complex that displays cellular toxicity. $53 \mathrm{Nat}$ Meet Italian Soc Biochem Mol Biol. Riccione, Italy, 2008;Sep 23-26 September 2008, Commun 15/15.

51. Spolaore B, Pinato O, Canton M, Zambonin M, Polverino de Laureto $P$, Fontana A. $\alpha$-Lactalbumin forms with oleic acid a high molecular weight complex displaying cytotoxic activity. Biochemistry. 2010;49(39):8658-67. 
52. Pettersson-Kastberg J, Mossberg AK, Trulsson $\mathrm{M}$, Yong $\mathrm{YJ}$, Min S, Lim Y, O'Brien JE, Svanborg C, Mok KH. Alpha-lactalbumin, engineered to be nonnative and inactive, kills tumor cells when in complex with oleic acid: a new biological function resulting from partial unfolding. J Mol Biol. 2009;394(5):994-1010.

53. Tolin S, De Franceschi G, Spolaore B, Frare E, Canton M, Polverino de Laureto P, Fontana A. The oleic acid complexes of proteolytic fragments of alpha-lactalbumin display apoptotic activity. FEBS J. 2010;277(1):163-73.

54. Ho JCS, Rydstrom A, Manimekalai MS, Svanborg C, Grüber G. Low resolution solution structure of HAMLET and the importance of its alpha-domains in tumoricidal activity. PLoS One. 2012;7(12):e53051.

55. Svensson M, Mossberg AK, Pettersson J, Linse $\mathrm{S}$, Svanborg C. Lipids as cofactors in protein folding: stereo-specific lipid-protein interactions are required to form HAMLET (human alpha-lactalbumin made lethal to tumor cells). Protein Sci. 2003;12(12):2805-14.

56. Köhler C, Håkansson A, Svanborg C, Orrenius $\mathrm{S}$, Zhivotovsky B. Protease activation in apoptosis induced by MAL. Exp Cell Res. 1999;249(2):260-8.

57. Düringer C, Hamiche A, Gustafsson L, Kimura $\mathrm{H}$, Svanborg C. HAMLET interacts with histones and chromatin in tumor cell nuclei. $\mathrm{J}$ Biol Chem. 2003;278(43):42131-5.

58. Trulsson M, Yu H, Gisselsson L, Chao Y, Urbano A, Aits S, Mossberg AK, Svanborg C. HAMLET binding to $\alpha$-actinin facilitates tumor cell detachment. PLoS One. 2011;6(3):e17179.

59. Ho J, Sielaff H, Nadeem A, Svanborg C, Grüber G. The Molecular Motor F-ATP Synthase Is Targeted by the Tumoricidal Protein HAMLET. J Mol Biol. 2015;427(10):1866-74.

60. Buchberger A, Bukau B, Sommer T. Protein quality control in the cytosol and the endoplasmic reticulum: brothers in arms. Mol Cell. 2010 Oct 22;40(2):238-52.

61. Hartl FU, Bracher A, Hayer-Hartl M. Molecular chaperones in protein folding and proteostasis. Nature. 2011 Jul 20;475(7356):324-32.

62. Sharp JA, Lefèvre C, Nicholas KR. Lack of functional alpha-lactalbumin prevents involution in Cape fur seals and identifies the protein as an apoptotic milk factor in mammary gland involution. BMC Biol. 2008 Nov 6;6:48.

63. $\mathrm{Xu} \mathrm{M,} \mathrm{Sugiura} \mathrm{Y,} \mathrm{Nagaoka} \mathrm{S,} \mathrm{Kanamaru} \mathrm{Y.}$ IEC-6 intestinal cell death induced by bovine milk alpha-lactalbumin. Biosci Biotechnol Biochem. 2005 Jun;69(6):1082-9.

64. Lin IC, Su SL, Kuo CD. Induction of cell death in RAW 264.7 cells by alpha-lactalbumin. Food Chem Toxicol. 2008 Mar;46(3):842-53.
65. Yang F Jr, Zhang M, Chen J, Liang Y. Structural changes of alpha-lactalbumin induced by low $\mathrm{pH}$ and oleic acid. Biochim Biophys Acta. 2006 Aug;1764(8):1389-96.

66. Chrysina ED, Brew K, Acharya KR. Crystal structures of apo- and holo-bovine alpha-lactalbumin at 2. 2-A resolution reveal an effect of calcium on inter-lobe interactions. J Biol Chem. 2000 Nov 24;275(47):37021-9.

67. Makowski L, Rodi DJ, Mandava S, Minh DD, Gore DB, Fischetti RF. Molecular crowding inhibits intramolecular breathing motions in proteins. J Mol Biol. 2008;375(2):529-46.

68. Baumann A, Gjerde AU, Ying M, Svanborg C, Holmsen H, Glomm WR, Martinez A, Halskau O. HAMLET forms annular oligomers when deposited with phospholipid monolayers. J Mol Biol. 2012;418(1-2):90-102.

69. Glatter O. The Interpretation of Real-Space Information from Small-Angle Scattering Experiments. J. Appl Cryst. 1979;12:166-75.

70. Jacques DA, Trewhella J. Small-angle scattering for structural biology--expanding the frontier while avoiding the pitfalls. Protein Sci. 2010 Apr;19(4):642-57.

71. Volkov VV, Svergun DI. Uniqueness of ab initio shape determination in small-angle scattering. J Appl Cryst 2003;36:860-4.

72. Ashbrook JD, Spector AA, Santos EC, Fletcher JE. Long chain fatty acid binding to human plasma albumin. J Biol Chem. 1975 Mar 25;250(6):2333-8.

73. Fasano M, Curry S, Terreno E, Galliano M, Fanali G, Narciso P, Notari S, Ascenzi P. The extraordinary ligand binding properties of human serum albumin. IUBMB Life. 2005;57(12):787-96.

74. Barbosa LR, Ortore MG, Spinozzi F, Mariani P, Bernstorff S, Itri R. The importance of proteinprotein interactions on the $\mathrm{pH}$-induced conformational changes of bovine serum albumin: a small-angle X-ray scattering study. Biophys J. 2010;98(1):147-57.

75. Petitpas I, Grüne T, Bhattacharya AA, Curry S. Crystal structures of human serum albumin complexed with monounsaturated and polyunsaturated fatty acids. J Mol Biol. 2001;314(5):955-60.

76. Nielsen SB, Wilhelm K, Vad B, Schleucher J, Morozova-Roche LA, Otzen D. The interaction of equine lysozyme:oleic acid complexes with lipid membranes suggests a cargo off-loading mechanism. J Mol Biol. 2010;398(2):351-61.

77. Svensson $M$, Sabharwal $\mathrm{H}$, Håkansson $\mathrm{A}$, Mossberg AK, Lipniunas P, Leffler H, Svanborg C, Linse S. Molecular characterization of alpha-lactalbumin folding variants that induce apoptosis in tumor cells. J Biol Chem. 
1999;274(10):6388-96.

78. Xie Y, Min S, Harte NP, Kirk H, O'Brien JE, Voorheis HP, Svanborg C, Hun Mok K. Electrostatic interactions play an essential role in the binding of oleic acid with $\alpha$-lactalbumin in the HAMLET-like complex: a study using charge-specific chemical modifications. Proteins. 2013;81(1):1-17.

79. Park YJ, Kim KH, Lim DW, Lee EK. Effects of $\mathrm{pH}$ and protein conformation on in-solution complexation between bovine $\alpha$-lactalbumin and oleic acid: Binding trend analysis by using SPR and ITC. Process Biochem. 2015.

80. Cistola DP, Atkinson D, Hamilton JA, Small DM. Phase behavior and bilayer properties of fatty acids: hydrated 1:1 acid-soaps. Biochemistry. 1986;25(10):2804-12.

81. Parks JS, Cistola DP, Small DM, Hamilton JA. Interactions of the carboxyl group of oleic acid with bovine serum albumin: a 13C NMR study. J Biol Chem. 1983;258(15):9262-9.

82. Chandra N, Brew K, Acharya KR. Structural evidence for the presence of a secondary calcium binding site in human alpha-lactalbumin. Biochemistry. 1998 Apr 7;37(14):4767-72.

83. Pike AC, Brew K, Acharya KR. Crystal structures of guinea-pig, goat and bovine alpha-lactalbumin highlight the enhanced conformational flexibility of regions that are significant for its action in lactose synthase. Structure. 1996;4(6):691-703.

84. Köhler C, Gogvadze V, Håkansson A, Svanborg C, Orrenius S, Zhivotovsky B. A folding variant of human alpha-lactalbumin induces mitochondrial permeability transition in isolated mitochondria. Eur J Biochem. 2001;268(1):18691.

85. Vukojević V, Bowen AM, Wilhelm K, Ming Y, Ce Z, Schleucher J, Hore PJ, Terenius L, Morozova-Roche LA. Lipoprotein complex of equine lysozyme with oleic acid (ELOA) interactions with the plasma membrane of live cells. Langmuir. 2010;26(18):14782-7.

86. Agasøster AV, Halskau Ø, Fuglebakk E, Frøystein NA, Muga A, Holmsen H, Martínez A. The interaction of peripheral proteins and membranes studied with alpha-lactalbumin and phospholipid bilayers of various compositions. J Biol Chem. 2003;278(24):21790-7.

87. Kleyman TR, Cragoe EJ Jr. Amiloride and its analogs as tools in the study of ion transport. J Membr Biol. 1988 Oct;105(1):1-21.

88. Palmer LG. Interactions of amiloride and other blocking cations with the apical $\mathrm{Na}$ channel in the toad urinary bladder. J Membr Biol. 1985;87(3):191-9.

89. Masereel B, Pochet L, Laeckmann D. An overview of inhibitors of $\mathrm{Na}(+) / \mathrm{H}(+)$ exchanger. Eur J Med Chem. 2003;38(6):547-54.

90. Iwamoto T, Watanabe Y, Kita S, Blaustein MP. $\mathrm{Na}+/ \mathrm{Ca} 2+$ exchange inhibitors: a new class of calcium regulators. Cardiovasc Hematol Disord Drug Targets. 2007;7(3):188-98.

91. Kellenberger S, Schild L. Epithelial sodium channel/degenerin family of ion channels: a variety of functions for a shared structure. Physiol Rev. 2002;82(3):735-67.

92. Garcia ML, King VF, Shevell JL, Slaughter RS, Suarez-Kurtz G, Winquist RJ, Kaczorowski GJ. Amiloride analogs inhibit L-type calcium channels and display calcium entry blocker activity. J Biol Chem. 1990 Mar 5;265(7):376371.

93. Tang CM, Presser F, Morad M. Amiloride selectively blocks the low threshold (T) calcium channel. Science. 1988 Apr 8;240(4849):213-5.

94. Hamill OP, McBride DW. The pharmacology of mechanogated membrane ion channels. Pharmacol Rev. 1996; 48: 231-252.

95. Jiang $\mathrm{Y}$, MacKinnon $\mathrm{R}$. The barium site in a potassium channel by x-ray crystallography. J Gen Physiol. 2000;115(3):269-72.

96. Lang PA, Kaiser S, Myssina S, Wieder T, Lang F, Huber SM. Role of Ca2+-activated $\mathrm{K}+$ channels in human erythrocyte apoptosis. Am J Physiol Cell Physiol. 2003 Dec;285(6):C155360.

97. Bortner CD, Hughes FM, Jr., Cidlowski JA. A primary role for $\mathrm{K}+$ and $\mathrm{Na}+$ efflux in the activation of apoptosis. J Biol Chem. 1997; 272: 32436-32442.

98. Nemeth R, Matijević E. Precipitation and electron microscopy of calcium- and bariumoleate sols. Kolloid-Zeitschrift und Zeitschrift für Polymere 1971;245(2):497-507.

99. Putney JW Jr. New molecular players in capacitative Ca2+ entry. J Cell Sci. 2007;120(Pt 12):1959-65.

100. Lytton J, Westlin M, Hanley MR. Thapsigargin inhibits the sarcoplasmic or endoplasmic reticulum Ca-ATPase family of calcium pumps. J Biol Chem. 1991;266(26):17067-71.

101. Mogami H, Lloyd Mills C, Gallacher DV. Phospholipase $\mathrm{C}$ inhibitor, U73122, releases intracellular $\mathrm{Ca} 2+$, potentiates $\mathrm{Ins}(1,4,5) \mathrm{P} 3$ mediated $\mathrm{Ca} 2+$ release and directly activates ion channels in mouse pancreatic acinar cells. Biochem J. 1997;324 (Pt 2):645-51.

102. Macmillan D, McCarron JG. The phospholipase C inhibitor U-73122 inhibits $\mathrm{Ca}(2+)$ release from the intracellular sarcoplasmic reticulum $\mathrm{Ca}(2+)$ store by inhibiting $\mathrm{Ca}(2+)$ pumps in smooth muscle. $\mathrm{Br} \mathrm{J}$ Pharmacol. 2010;160(6):1295-301.

103. Kargacin GJ, Ali Z, Kargacin ME. Ruthenium 
red reduces the $\mathrm{Ca} 2+$ sensitivity of $\mathrm{Ca} 2+$ uptake into cardiac sarcoplasmic reticulum. Pflugers Arch. 1998;436(3):338-42.

104. Malécot CO, Bito V, Argibay JA. Ruthenium red as an effective blocker of calcium and sodium currents in guinea-pig isolated ventricular heart cells. Br J Pharmacol. 1998;124(3):465-72.

105. Kataev AA, Zherelova OM, Berestovsky GN. Ca2+-induced activation and irreversible inactivation of chloride channels in the perfused plasmalemma of Nitellopsis obtusa. Gen Physiol Biophys. 1984;3(6):447-62.

106. Lönnerdal B, Glazier C. Calcium binding by alpha-lactalbumin in human milk and bovine milk. J Nutr. 1985;115(9):1209-16.

107. Zaloga GP, Willey S, Tomasic P, Chernow B. Free fatty acids alter calcium binding: a cause for misinterpretation of serum calcium values and hypocalcemia in critical illness. J Clin Endocrinol Metab. 1987;64(5):1010-4.

108. Mermier P, Hasselbach W. The biphasic active transport of calcium by the fragmented sarcoplasmic reticulum as revealed by the flow dialysis method. Eur J Biochem. 1976;64(2):613-20.

109. Mermier P, Hasselbach W. Comparison between strontium and calcium uptake by the fragmented sarcoplasmic reticulum. Eur J Biochem. 1976;69(1):79-86.

110. Mossberg AK, Puchades M, Halskau Ø, Baumann A, Lanekoff I, Chao Y, Martinez A, Svanborg C, Karlsson R. HAMLET interacts with lipid membranes and perturbs their structure and integrity. PLoS One. 2010;5(2):e9384.

111. Wen H, Glomm WR, Halskau O. Cytotoxicity of bovine $\alpha$-lactalbumin: oleic acid complexes correlates with the disruption of lipid membranes. Biochim Biophys Acta. 2013;1828(11):2691-9.

112. Bauer B, Davidson M, Orwar O. Direct reconstitution of plasma membrane lipids and proteins in nanotube-vesicle networks. Langmuir. 2006;22(22):9329-32.

113. Ongpipattanakul B, Burnette RR, Potts RO, Francoeur ML. Evidence that oleic acid exists in a separate phase within stratum corneum lipids. Pharm Res. 1991;8(3):350-4.

114. Turunen TM, Urtti A, Paronen P, Audus KL, Rytting JH. Effect of some penetration enhancers on epithelial membrane lipid domains: evidence from fluorescence spectroscopy studies. Pharm Res. 1994;11(2):288-94.

115. Baconguis I, Bohlen CJ, Goehring A, Julius D, Gouaux E. X-ray structure of acid-sensing ion channel 1-snake toxin complex reveals open state of a $\mathrm{Na}(+)$-selective channel. Cell. 2014
Feb 13;156(4):717-29

116. Wöhlert D, Kühlbrandt W, Yildiz O. Structure and substrate ion binding in the sodium/proton antiporter PaNhaP. Elife. 2014 Nov 26;3:e03579.

117. Ammar YB, Takeda S, Hisamitsu T, Mori H, Wakabayashi S. Crystal structure of CHP2 complexed with NHE1-cytosolic region and an implication for $\mathrm{pH}$ regulation. EMBO J. 2006 Jun 7;25(11):2315-25.

118. Liao J, Li H, Zeng W, Sauer DB, Belmares R, Jiang Y. Structural insight into the ion-exchange mechanism of the sodium/calcium exchanger. Science. 2012 Feb 10;335(6069):686-90.

119. Yang J, Dokurno P, Tonks NK, Barford D. Crystal structure of the M-fragment of alphacatenin: implications for modulation of cell adhesion. EMBO J. 2001 Jul 16;20(14):364556.

120. Hilge M, Aelen J, Vuister GW. Ca2+ regulation in the $\mathrm{Na}+\mathrm{Ca} 2+$ exchanger involves two markedly different $\mathrm{Ca} 2+$ sensors. Mol Cell. 2006 Apr 7;22(1):15-25.

121. Brini M, Carafoli E.The plasma membrane $\mathrm{Ca}^{2}+$ ATPase and the plasma membrane sodium calcium exchanger cooperate in the regulation of cell calcium. Cold Spring Harb Perspect Biol. 2011 Feb 1;3(2).

122. Bieging KT, Mello SS, Attardi LD. Unravelling mechanisms of p53-mediated tumour suppression. Nat Rev Cancer. 2014;14(5):35970.

123. Czabotar PE, Lessene G, Strasser A, Adams JM. Control of apoptosis by the BCL-2 protein family: implications for physiology and therapy. Nat Rev Mol Cell Biol. 2014;15(1):49-63.

124. Kang R, Zeh HJ, Lotze MT, Tang D. The Beclin 1 network regulates autophagy and apoptosis. Cell Death Differ. 2011;18(4):571-80.

125. Shen S, Kepp O, Kroemer G. The end of autophagic cell death? Autophagy. 2012 Jan;8(1):1-3.

126. Ryter SW, Mizumura K, Choi AM. The impact of autophagy on cell death modalities. Int J Cell Biol. 2014;2014:502676.

127. Liu Y, Levine B. Autosis and autophagic cell death: the dark side of autophagy. Cell Death Differ. 2015;22(3):367-76.

128. Aits S, Gustafsson L, Hallgren O, Brest P, Gustafsson M, Trulsson M, Mossberg AK, Simon HU, Mograbi B, Svanborg C. HAMLET (human alpha-lactalbumin made lethal to tumor cells) triggers autophagic tumor cell death. Int $\mathrm{J}$ Cancer. 2009;124(5):1008-19.

129. Lilienbaum A. Relationship between the proteasomal system and autophagy. Int $\mathrm{J}$ Biochem Mol Biol. 2013;4(1):1-26.

130. Permyakov SE, Pershikova IV, Khokhlova TI, 
Uversky VN, Permyakov EA. No need to be HAMLET or BAMLET to interact with histones: binding of monomeric alpha-lactalbumin to histones and basic polyamino acids. Biochemistry. 2004 May 18;43(19):5575-82.

131. Broekemeier KM, Krebsbach RJ, Pfeiffer DR. Inhibition of the mitochondrial $\mathrm{Ca} 2+$ uniporter by pure and impure ruthenium red. Mol Cell Biochem. 1994;139(1):33-40.

132. Watanabe N, Yamada S. Activation of $20 \mathrm{~S}$ proteasomes from spinach leaves by fatty acids. Plant Cell Physiol. 1996;37(2):147-51.

133. Sjöblom B, Salmazo A, Djinović-Carugo K. Alpha-actinin structure and regulation. Cell Mol Life Sci. 2008;65(17):2688-701.

134. Ho JC, Nadeem A, Rydström A, Puthia M, Svanborg C. Targeting of nucleotide-binding proteins by HAMLET-a conserved tumor cell death mechanism. Oncogene. 2015 Jun 1.

135. Alavian KN, Li H, Collis L, Bonanni L, Zeng L, Sacchetti S, Lazrove E, Nabili P, Flaherty B, Graham M, Chen Y, Messerli SM, Mariggio MA, Rahner C, McNay E, Shore GC, Smith PJ, Hardwick JM, Jonas EA. Bcl-xL regulates metabolic efficiency of neurons through interaction with the mitochondrial F1FO ATP synthase. Nat Cell Biol. 2011 Sep 18;13(10):1224-33.

136. García J. The calcium channel $\alpha 2 / \delta 1$ subunit interacts with ATP5b in the plasma membrane of developing muscle cells. Am J Physiol Cell Physiol. 2011 Jul;301(1):C44-52.

137. Guo XG, Liu CT, Dai H, Guo QN. Mutations in the mitochondrial ATPase6 gene are frequent in human osteosarcoma. Exp Mol Pathol. 2013 Feb;94(1):285-8.

138. Grzybowska-Szatkowska L, Slaska B, Rzymowska J, Brzozowska A, Floriańczyk B. Novel mitochondrial mutations in the ATP6 and ATP8 genes in patients with breast cancer. Mol Med Rep. 2014 Oct;10(4):1772-8.

139. Yacoub HA, Mahmoud WM, El-Baz HA, Eid OM, El-Fayoumi RI, Mahmoud MM, Harakeh $\mathrm{S}$, Abuzinadah OH. New Haplotypes of the ATP Synthase Subunit 6 Gene of Mitochondrial DNA are Associated with Acute Lymphoblastic Leukemia in Saudi Arabia. Asian Pac J Cancer Prev. 2014;15(23):10433-8.

140. Kim BW, Choo HJ, Lee JW, Kim JH, Ko YG. Extracellular ATP is generated by ATP synthase complex in adipocyte lipid rafts. Exp Mol Med. 2004 Oct 31;36(5):476-85.

141. Dabbeni-Sala F, Rai AK, Lippe G. Chapter 8. F0F1 ATP Synthase: A fascinating challenge for proteomic. pp 162-188. In "Proteomics- Human Diseases and Protein Functions" Ed. Tsz-Kwong Man and Ricardo J. Flores.
Publisher: InTech, Chapters. ISBN 978-953307-832-8. Published: February 10, 2012.

142. Moser TL, Stack MS, Asplin I, Enghild JJ, Højrup P, Everitt L, Hubchak S, Schnaper HW, Pizzo SV. Angiostatin binds ATP synthase on the surface of human endothelial cells. Proc Natl Acad Sci U S A. 1999;96(6):2811-6.

143. Moser TL, Kenan DJ, Ashley TA, Roy JA, Goodman MD, Misra UK, Cheek DJ, Pizzo SV. Endothelial cell surface F1-F0 ATP synthase is active in ATP synthesis and is inhibited by angiostatin. Proc Natl Acad Sci U S A. 2001;98(12):6656-61.

144. Radojkovic C, Genoux A, Pons V, Combes G, de Jonge H, Champagne E, Rolland C, Perret B, Collet X, Tercé F, Martinez LO. Stimulation of cell surface F1-ATPase activity by apolipoprotein A-I inhibits endothelial cell apoptosis and promotes proliferation. Arterioscler Thromb Vasc Biol. 2009 Jul;29(7):1125-30.

145. Yamamoto K, Sokabe T, Ohura N, Nakatsuka H, Kamiya A, Ando J. Endogenously released ATP mediates shear stress-induced $\mathrm{Ca} 2+$ influx into pulmonary artery endothelial cells. Am J Physiol Heart Circ Physiol. 2003;285(2):H793803.

146. Yamamoto K, Shimizu N, Obi S, Kumagaya S, Taketani Y, Kamiya A, Ando J. Involvement of cell surface ATP synthase in flow-induced ATP release by vascular endothelial cells. Am J Physiol Heart Circ Physiol. 2007;293(3):H164653.

147. Arakaki N, Nagao T, Niki R, Toyofuku A, Tanaka H, Kuramoto Y, Emoto Y, Shibata H, Magota K, Higuti T. Possible role of cell surface $\mathrm{H}+$-ATP synthase in the extracellular ATP synthesis and proliferation of human umbilical vein endothelial cells. Mol Cancer Res. 2003 Nov;1(13):931-9.

148. Kawai Y, Yokoyama Y, Kaidoh M, Ohhashi T. Shear stress-induced ATP-mediated endothelial constitutive nitric oxide synthase expression in human lymphatic endothelial cells. Am J Physiol Cell Physiol. 2010;298(3):C647-55.

149. Cavelier C, Ohnsorg PM, Rohrer L, von Eckardstein A. The $\beta$-chain of cell surface $\mathrm{F}(0) \mathrm{F}(1)$ ATPase modulates apoA-I and HDL transcytosis through aortic endothelial cells. Arterioscler Thromb Vasc Biol. 2012 Jan;32(1):131-9.

150. Martinez LO, Jacquet S, Esteve JP, Rolland C, Cabezón E, Champagne E, Pineau T, Georgeaud V, Walker JE, Tercé F, Collet X, Perret B, Barbaras R. Ectopic beta-chain of ATP synthase is an apolipoprotein A-I receptor in hepatic HDL endocytosis. Nature. 2003 Jan 2;421(6918):759. 
151. Burrell HE. Human keratinocytes release ATP and utilize three mechanisms for nucleotide interconversion at the cell surface. J Biol Chem 2005;280:29667-76.

152. Yavlovich A, Viard M, Zhou M, Veenstra TD, Wang JM, Gong W, Heldman E, Blumenthal R, Raviv Y. Ectopic ATP synthase facilitates transfer of HIV-1 from antigen-presenting cells to $\mathrm{CD} 4(+)$ target cells. Blood. $2012 \mathrm{Aug}$ 9;120(6):1246-53.

153. Xing SL, Yan J, Yu ZH, Zhu CQ. Neuronal cell surface ATP synthase mediates synthesis of extracellular ATP and regulation of intracellular pH. Cell Biol Int. 2011 Jan;35(1):81-6.

154. Kowalski-Chauvel A, Najib S, Tikhonova IG, Huc L, Lopez F, Martinez LO, Cohen-JonathanMoyal E, Ferrand A, Seva C. Identification of the F1-ATPase at the cell surface of colonic epithelial cells: role in mediating cell proliferation. J Biol Chem. 2012 Nov 30;287(49):41458-68.

155. Park M, Lin L, Thomas S, Braymer HD, Smith PM, Harrison DH, York DA. The F1-ATPase beta-subunit is the putative enterostatin receptor. Peptides. 2004 Dec;25(12):2127-33.

156. Das B, Mondragon MO, Sadeghian M, Hatcher VB, Norin AJ. A novel ligand in lymphocytemediated cytotoxicity: expression of the beta subunit of $\mathrm{H}+$ transporting ATP synthase on the surface of tumor cell lines. J Exp Med. 1994 Jul 1;180(1):273-81.

157. Chang HY, Huang HC, Huang TC, Yang PC, Wang YC, Juan HF. Ectopic ATP synthase blockade suppresses lung adenocarcinoma growth by activating the unfolded protein response. Cancer Res. 2012;72(18):4696-706.

158. von Haller PD, Donohoe S, Goodlett DR, Aebersold R, Watts JD. Mass spectrometric characterization of proteins extracted from Jurkat $\mathrm{T}$ cell detergent-resistant membrane domains. Proteomics. 2001 Aug;1(8):1010-21.

159. Yonally SK, Capaldi RA. The F(1)F(0) ATP synthase and mitochondrial respiratory chain complexes are present on the plasma membrane of an osteosarcoma cell line: An immunocytochemical study. Mitochondrion. 2006 Dec;6(6):305-14.

160. Rai, Amit Kumar. PhD Thesis. Proteomic and immunofluorescence studies of ectopic F0F1 ATP synthase: A novel pharmacological target of HDL indocytosis in liver. Università degli Studi di Padova, Italy, 2013.

161. Pan J, Sun LC, Tao YF, Zhou Z, Du XL, Peng L, Feng X, Wang J, Li YP, Liu L, Wu SY, Zhang YL, Hu SY, Zhao WL, Zhu XM, Lou GL, Ni J. ATP synthase ecto- $\alpha$-subunit: a novel therapeutic target for breast cancer. J Transl Med. 2011;9:211.
162. Fliedner SM, Yang C, Thompson E, Abu-Asab M, Hsu CM, Lampert G, Eiden L, Tischler AS, Wesley R, Zhuang Z, Lehnert H, Pacak K. Potential therapeutic target for malignant paragangliomas: ATP synthase on the surface of paraganglioma cells. Am J Cancer Res. 2015 Mar 15;5(4):1558-70.

163. Scotet E, Martinez LO, Grant E, Barbaras R, Jenö P, Guiraud $\mathrm{M}$ et al. Tumor recognition following $\mathrm{V} \gamma 9 \mathrm{~V} \delta 2 \mathrm{~T}$ cell receptor interactions with a surface F1-ATPase-related structure and apolipoprotein AI. Immunity 2005;22:71-80.

164. Mookerjee-Basu J, Vantourout P, Martinez LO, Perret B, Collet X, Périgaud C, Peyrottes S, Champagne E. F1-adenosine triphosphatase displays properties characteristic of an antigen presentation molecule for Vgamma9Vdelta2 $\mathrm{T}$ cells. J Immunol. 2010 Jun 15;184(12):6920-8.

165. Lu ZJ, Song QF, Jiang SS, Song Q, Wang W, Zhang GH, Kan B, Chen LJ, Yang JL, Luo F, Qian ZY, Wei YQ, Gou LT. Identification of ATP synthase beta subunit (ATPB) on the cell surface as a non-small cell lung cancer (NSCLC) associated antigen. BMC Cancer. 2009 Jan 14;9:16.

166. Chi SL, Pizzo SV. Angiostatin is directly cytotoxic to tumor cells at low extracellular $\mathrm{pH}$ : a mechanism dependent on cell surfaceassociated ATP synthase. Cancer Res 2006;66:875-882.

167. Chang HY, Huang TC, Chen NN, Huang HC, Juan HF. Combination therapy targeting ectopic ATP synthase and 26S proteasome induces ER stress in breast cancer cells. Cell Death Dis. 2014;5:e1540.

168. Huang TC, Chang HY, Hsu CH, Kuo WH, Chang KJ, Juan HF. Targeting therapy for breast carcinoma by ATP synthase inhibitor aurovertin B. J Proteome Res 2008;7:1433-44.

169. Zhang X, Gao F, Peng Y, Yin M, Ni J. Dual functions of a monoclonal antibody against cell surface F1F0 ATP synthase on both HUVEC and tumor cells. Acta Pharmacol Sin 2008; 29:42-950.

170. Deshpande M, Notari L, Subramanian P, Notario V, Becerra SP. Inhibition of tumor cell surface ATP synthesis by pigment epitheliumderived factor: implications for antitumor activity. Int J Oncol. 2012 Jul;41(1):219-27.

171. Soltys BJ, Gupta RS. Mitochondrial-matrix proteins at unexpected locations: are they exported? Trends Biochem Sci. 1999 May;24(5):174-7.

172. Vantourout P, Radojkovic C, Lichtenstein L, Pons V, Champagne E, Martinez LO. Ecto-F1ATPase: a moonlighting protein complex and an unexpected apoA-I receptor. World J Gastroenterol. 2010 Dec 21;16(47):5925-35. 
173. Ma Z, Cao M, Liu Y, He Y, Wang Y, Yang C, Wang W, Du Y, Zhou M, Gao F. Mitochondrial F1Fo-ATP synthase translocates to cell surface in hepatocytes and has high activity in tumorlike acidic and hypoxic environment. Acta Biochim Biophys Sin (Shanghai). 2010 Aug;42(8):530-7.

174. Wang T, Chen Z, Wang X, Shyy JY, Zhu Y. Cholesterol loading increases the translocation of ATP synthase beta chain into membrane caveolae in vascular endothelial cells. Biochim Biophys Acta. 2006 Oct;1761(10):1182-90.

175. Lyly A, Marjavaara SK, Kyttälä A, Uusi-Rauva K, Luiro K, Kopra O, Martinez LO, Tanhuanpää K, Kalkkinen N, Suomalainen A, Jauhiainen M, Jalanko A. Deficiency of the INCL protein Ppt1 results in changes in ectopic F1-ATP synthase and altered cholesterol metabolism. Hum Mol Genet. 2008 May 15;17(10):1406-17.

176. Guest MM, Bond TP, Cooper RG, Derrick JR. Red blood cells: Change in shape in capillaries. Science. 1963;142(3597):1319-21.

177. Hoffman JF, Inoué S. Directly observed reversible shape changes and hemoglobin stratification during centrifugation of human and Amphiuma red blood cells. Proc Natl Acad Sci USA. 2006 Feb 21;103(8):2971-6.

178. Diez-Silva M, Dao M, Han J, Lim CT, Suresh S. Shape and Biomechanical Characteristics of Human Red Blood Cells in Health and Disease. MRS Bull. 2010;35(5):382-388.

179. Brecher G, Bessis M. Present status of spiculed red cells and their relationship to the discocyteechinocyte transformation: a critical review. Blood. 1972 Sep;40(3):333-44.

180. Csordas A, Schauenstein K. Structure- and configuration-dependent effects of C18 unsaturated fatty acids on the chicken and sheep erythrocyte membrane. Biochim Biophys Acta. 1984 Feb 15;769(3):571-7.

181. McPhedran WF. On the hemolytic properties of fatty acids and their relation to the causation of toxic hemolysis and pernicious anemia. J Exp Med. 1913 Nov 1;18(5):527-42.

182. Kotagal N, Colca JR, McDaniel ML. Activation of an islet cell plasma membrane $(\mathrm{Ca} 2++$ $\mathrm{Mg} 2+$ )-ATPase by calmodulin and Ca-EGTA. J Biol Chem. 1983 Apr 25;258(8):4808-13.

183. Toyoshima C, Nakasako M, Nomura H, Ogawa H. Crystal structure of the calcium pump of sarcoplasmic reticulum at $2.6 \mathrm{~A}$ resolution. Nature. 2000 Jun 8;405(6787):647-55.

184. Carafoli E. Calcium pump of the plasma membrane. Physiol Rev. 1991 Jan;71(1):129-53.

185. Ronner P, Gazzotti P, Carafoli E. A lipid requirement for the $(\mathrm{Ca} 2++\mathrm{Mg} 2+)$-activated ATPase of erythrocyte membranes. Arch Biochem Biophys. 1977 Mar;179(2):578-83.
186. Nelson DR, Hanahan DJ. Phospholipid and detergent effects on $(\mathrm{Ca} 2++\mathrm{Mg} 2+)$ ATPase purified from human erythrocytes. Arch Biochem Biophys. 1985 Feb 1;236(2):720-30.

187. Lopreiato R, Giacomello M, Carafoli E. The plasma membrane calcium pump: new ways to look at an old enzyme. J Biol Chem. 2014 Apr 11;289(15):10261-8.

188. Lucke B, McCutcheon M. The living cell as an osmotic system and its permeability to water. Physiol Rev. 1932;12:68.

189. Rubin RP. Calcium and cellular secretion Plenum Press, New York. 1982.

190. Newton C, Pangborn W, Nir S, Papahadjopoulos D. Specificity of $\mathrm{Ca} 2+$ and $\mathrm{Mg} 2+$ binding to phosphatidylserine vesicles and resultant phase changes of bilayer membrane structure. Biochim Biophys Acta. 1978 Jan 19;506(2):281-7.

191. Kuo P, Weinfeld M, Rudd MA, Amarante P, Loscalzo J. Plasma membrane enrichment with cis-unsaturated fatty acids enhances LDL metabolism in U937 monocytes. Arteriosclerosis. 1990 Jan-Feb;10(1):111-8.

192. Klausner RD, Kleinfeld AM, Hoover RL, Karnovsky MJ. Lipid domains in membranes. Evidence derived from structural perturbations induced by free fatty acids and lifetime heterogeneity analysis. J Biol Chem. 1980 Feb 25;255(4):1286-95.

193. Raz-Prag D, Zeng Y, Sieving PA, Bush RA. Photoreceptor protection by adeno-associated virus-mediated LEDGF expression in the RCS rat model of retinal degeneration: probing the mechanism. Invest Ophthalmol Vis Sci. 2009;50(8):3897-906.

194. Mayer MP, Bukau B. Hsp70 chaperones: cellular functions and molecular mechanism. Cell Mol Life Sci. 2005;62(6):670-84.

195. Peisker K, Chiabudini M, Rospert S. The ribosome-bound Hsp70 homolog Ssb of Saccharomyces cerevisiae. Biochim Biophys Acta. 2010;1803(6):662-72.

196. Guidon PT Jr, Hightower LE. Purification and initial characterization of the 71-kilodalton rat heat-shock protein and its cognate as fatty acid binding proteins. Biochemistry. 1986;25(11):3231-9.

197. Guidon PT Jr, Hightower LE. The 73 kilodalton heat shock cognate protein purified from rat brain contains nonesterified palmitic and stearic acids. J Cell Physiol. 1986;128(2):239-45.

198. Arispe N, Doh M, De Maio A. Lipid interaction differentiates the constitutive and stress-induced heat shock proteins Hsc70 and Hsp70. Cell Stress Chaperones. 2002;7(4):330-8.

199. Awasthi S, Madhusoodhanan R, Wolf R. Surfactant protein-A and toll-like receptor-4 modulate immune functions of preterm baboon 
lung dendritic cell precursor cells. Cell Immunol. 2011;268(2):87-96.

200. Flannagan RS, Jaumouillé V, Grinstein S. The cell biology of phagocytosis. Annu Rev Pathol. 2012;7:61-98.

201. Zaritsky A, Woldringh CL. Chromosome replication rate and cell shape in Escherichia coli: lack of coupling. J Bacteriol. 1978 Aug135(2):581-7.

202. Whitby FG, Masters EI, Kramer L, Knowlton JR, Yao Y, Wang CC, Hill CP. Structural basis for the activation of $20 \mathrm{~S}$ proteasomes by $11 \mathrm{~S}$ regulators. Nature. 2000 Nov 2;408(6808):11520.

203. Ribeiro Ede A Jr, Pinotsis N, Ghisleni A, Salmazo A, Konarev PV, Kostan J, Sjöblom B, Schreiner C, Polyansky AA, Gkougkoulia EA, Holt MR, Aachmann FL, Zagrović B, Bordignon E, Pirker KF, Svergun DI, Gautel M, Djinović-Carugo K. The structure and regulation of human muscle $\alpha$-actinin. Cell. 2014 Dec 4;159(6):1447-60.

204. Stock D, Leslie AG, Walker JE. Molecular architecture of the rotary motor in ATP synthase. Science. 1999 Nov 26;286(5445):1700-5.

205. Lönnerdal B, Forsum E, Hambraeus L. A longitudinal study of the protein, nitrogen, and lactose contents of human milk from Swedish well-nourished mothers. Am J Clin Nutr. 1976;29(10):1127-33.

206. Lönnerdal B, Forsum E, Gebre-Medhin M, Hambraeus L. Breast milk composition in Ethiopian and Swedish mothers. II. Lactose, nitrogen, and protein contents. Am J Clin Nutr. 1976;29(10):1134-41.

207. Lönnerdal B, Forsum E, Hambraeus L. Effect of oral contraceptives on composition and volume of breast milk. Am J Clin Nutr. 1980;33(4):81624.

208. Jensen RG. Lipids in human milk. Lipids. 1999;34(12):1243-71.

209. Bobe G, Beitz DC, Freeman AE, Lindberg GL. Separation and Quantification of Bovine Milk Proteins by Reversed-Phase High-Performance Liquid Chromatography. J Agric Food Chem. 1998 Feb;46(2):458-463.

210. Månsson HL. Fatty acids in bovine milk fat. Food Nutr Res. 2008;52.

211. Salentinig S, Phan S, Hawley A, Boyd BJ. Selfassembly structure formation during the digestion of human breast milk. Angew Chem Int Ed Engl. 2015;54(5):1600-3.

212. Sullivan LM, Kehoe JJ, Barry L, Buckley MJ, Shanahan F, Mok KH, Brodkorb A. Gastric digestion of $\alpha$-lactalbumin in adult human subjects using capsule endoscopy and nasogastric tube sampling. $\mathrm{Br} \mathrm{J}$ Nutr. 2014;112(4):638-46.
213. Mitchell DJ, McClure BG, Tubman TR. Simultaneous monitoring of gastric and oesophageal $\mathrm{pH}$ reveals limitations of conventional oesophageal $\mathrm{pH}$ monitoring in milk fed infants. Arch Dis Child. 2001;84(3):273-6.

214. Sullivan LM, Mok KH, Brodkorb A. The Formation of an Anti-Cancer Complex Under Simulated Gastric Conditions. Food Digestion 2013;4(1):7-18.

215. Rough SM, Sakamoto P, Fee CH, Hollenbeck CB. Qualitative analysis of cancer patients' experiences using donated human milk. J Hum Lact. 2009;25(2):211-9.

216. UK Childhood Cancer Study Investigators. Breastfeeding and childhood cancer. $\mathrm{Br} \mathrm{J}$ Cancer. 2001;85(11):1685-94.

217. Martin RM, Middleton N, Gunnell D, Owen CG, Smith GD. Breast-feeding and cancer: the Boyd Orr cohort and a systematic review with meta-analysis. J Natl Cancer Inst. 2005;97(19):1446-57.

218. Harding NJ, Birch JM, Hepworth SJ, McKinney PA; UKCCS Investigators. Breastfeeding and risk of childhood CNS tumours. Br J Cancer. 2007;96(5):815-7.

219. Wang KL, Liu CL, Zhuang Y, Qu HY. Breastfeeding and the risk of childhood Hodgkin lymphoma: a systematic review and meta-analysis. Asian Pac J Cancer Prev. 2013;14(8):4733-7.

220. Fridman R, Sweeney TM, Zain M, Martin GR, Kleinman HK. Malignant transformation of NIH-3T3 cells after subcutaneous co-injection with a reconstituted basement membrane (matrigel). Int J Cancer. 1992 Jul 9;51(5):740-4.

221. Levenbook IS, Petricciani JC, Elisberg BL. Tumorigenicity of Vero cells. J Biol Stand. 1984 Oct;12(4):391-8.

222. Omeir RL, Teferedegne B, Foseh GS, Beren JJ, Snoy PJ, Brinster LR, Cook JL, Peden K, Lewis AM Jr. Heterogeneity of the tumorigenic phenotype expressed by Madin-Darby canine kidney cells. Comp Med. 2011 Jun;61(3):24350.

223. Brinster LR, Omeir RL, Foseh GS, Macauley JN, Snoy PJ, Beren JJ, Teferedegne B, Peden K, Lewis AM Jr. Failure-to-thrive syndrome associated with tumor formation by MadinDarby canine kidney cells in newborn nude mice. Comp Med. 2013 Aug;63(4):323-30.

224. Jamin Y, Boult JK, Li J, Popov S, Garteiser P, Ulloa JL, Cummings C, Box G, Eccles SA, Jones C, Waterton JC, Bamber JC, Sinkus R, Robinson SP. Exploring the biomechanical properties of brain malignancies and their pathologic determinants in vivo with magnetic resonance elastography. Cancer Res. 2015 Apr 
1;75(7):1216-24.

225. Rother J, Nöding H, Mey I, Janshoff A. Atomic force microscopy-based microrheology reveals significant differences in the viscoelastic response between malign and benign cell lines. Open Biol. 2014 May;4(5):140046.

226. Physical Sciences - Oncology Centers Network, Agus DB, Alexander JF, Arap W, Ashili S, Aslan JE, Austin RH, Backman V, Bethel KJ, Bonneau $\mathrm{R}$, Chen WC, Chen-Tanyolac C, Choi NC, Curley SA, Dallas M, Damania D, Davies PC, Decuzzi P, Dickinson L, Estevez-Salmeron L, Estrella V, Ferrari M, Fischbach C, Foo J, Fraley SI, Frantz C, Fuhrmann A, Gascard P, Gatenby RA, Geng Y, Gerecht S, Gillies RJ, Godin B, Grady WM, Greenfield A, Hemphill C, Hempstead BL, Hielscher A, Hillis WD, Holland EC, Ibrahim-Hashim A, Jacks T, Johnson RH, Joo A, Katz JE, Kelbauskas L, Kesselman C, King MR, Konstantopoulos K, Kraning-Rush CM, Kuhn P, Kung K, Kwee B, Lakins JN, Lambert G, Liao D, Licht JD, Liphardt JT, Liu L, Lloyd MC, Lyubimova A, Mallick P, Marko J, McCarty OJ, Meldrum DR, Michor F, Mumenthaler SM, Nandakumar V, O'Halloran TV, Oh S, Pasqualini R, Paszek MJ, Philips KG, Poultney CS, Rana K, ReinhartKing CA, Ros R, Semenza GL, Senechal P, Shuler ML, Srinivasan S, Staunton JR, Stypula Y, Subramanian H, Tlsty TD, Tormoen GW, Tseng Y, van Oudenaarden A, Verbridge SS, Wan JC, Weaver VM, Widom J, Will C, Wirtz D, Wojtkowiak J, Wu PH. A physical sciences network characterization of non-tumorigenic and metastatic cells. Sci Rep. 2013;3:1449.

227. Swaminathan V, Mythreye K, O'Brien ET, Berchuck A, Blobe GC, Superfine R. Mechanical stiffness grades metastatic potential in patient tumor cells and in cancer cell lines. Cancer Res. 2011 Aug 1;71(15):5075-80.

228. Cross SE, Jin YS, Tondre J, Wong R, Rao J, Gimzewski JK. AFM-based analysis of human metastatic cancer cells. Nanotechnology. 2008 Sep 24;19(38):384003.

229. Cross SE, Jin YS, Rao J, Gimzewski JK. Nanomechanical analysis of cells from cancer patients. Nat Nanotechnol. 2007 Dec;2(12):7803.

230. Suresh S, Spatz J, Mills JP, Micoulet A, Dao M, Lim CT, Beil M, Seufferlein T. Connections between single-cell biomechanics and human disease states: gastrointestinal cancer and malaria. Acta Biomater. 2005 Jan;1(1):15-30.

231. Apostolov K, Barker W, Catovsky D, Goldman J, Matutes E. Reduction in the stearic to oleic acid ratio in leukaemic cells--a possible chemical marker of malignancy. Blut. 1985; 50: 349-354.
232. Wood CB, Habib NA, Apostolov K, Kersten D, Barker W, Smadja C et al. Reduction in the stearic to oleic acid ratio in the circulating red blood cells: a possible tumour marker in solid human neoplasms. Eur J Surg Oncol. 1985; 11: 167-169.

233. Jonas EA, Porter GA Jr, Beutner G, Mnatsakanyan N, Alavian KN. Cell death disguised: The mitochondrial permeability transition pore as the c-subunit of the F1FO ATP synthase. Pharmacol Res. 2015 May 5. pii: S1043-6618(15)00081-X. doi: 10.1016/j.phrs.2015.04.013.

234. Bonora M, Bononi A, De Marchi E, Giorgi C, Lebiedzinska M, Marchi S, Patergnani S, Rimessi A, Suski JM, Wojtala A, Wieckowski MR, Kroemer G, Galluzzi L, Pinton P. Role of the $\mathrm{c}$ subunit of the FO ATP synthase in mitochondrial permeability transition. Cell Cycle. 2013;12(4):674-83.

235. Giorgio V, von Stockum S, Antoniel M, Fabbro A, Fogolari F, Forte M, Glick GD, Petronilli V, Zoratti M, Szabó I, Lippe G, Bernardi P. Dimers of mitochondrial ATP synthase form the permeability transition pore. Proc Natl Acad Sci U S A. 2013;110(15):5887-92.

236. Alavian KN, Beutner G, Lazrove E, Sacchetti S, Park HA, Licznerski P, Li H, Nabili P, Hockensmith K, Graham M, Porter GA Jr, Jonas EA. An uncoupling channel within the c-subunit ring of the F1FO ATP synthase is the mitochondrial permeability transition pore. Proc Natl Acad Sci U S A. 2014;111(29):10580-5.

237. Carraro M, Giorgio V, Šileikyte J, Sartori G, Forte M, Lippe G, Zoratti M, Szabò I, Bernardi P. Channel formation by yeast F-ATP synthase and the role of dimerization in the mitochondrial permeability transition. J Biol Chem. 2014;289(23):15980-5.

238. Halestrap AP, Richardson AP. The mitochondrial permeability transition: a current perspective on its identity and role in ischaemia/reperfusion injury. J Mol Cell Cardiol. 2015;78:129-41.

239. Shchepina LA, Pletjushkina OY, Avetisyan AV, Bakeeva LE, Fetisova EK, Izyumov DS, Saprunova VB, Vyssokikh MY, Chernyak BV, Skulachev VP. Oligomycin, inhibitor of the F0 part of H+-ATP-synthase, suppresses the TNFinduced apoptosis. Oncogene. 2002 Nov 21;21(53):8149-57.

240. Sánchez-Aragó M, Formentini L, Cuezva JM. Mitochondria-mediated energy adaption in cancer: the $\mathrm{H}(+)$-ATP synthase-geared switch of metabolism in human tumors. Antioxid Redox Signal. 2013 Jul 20;19(3):285-98.

241. Shin YK, Yoo BC, Chang HJ, Jeon E, Hong SH, Jung MS, Lim SJ, Park JG. Down-regulation of 
mitochondrial F1F0-ATP synthase in human colon cancer cells with induced 5-fluorouracil resistance. Cancer Res. 2005 Apr 15;65(8):3162-70.

242. Sánchez-Aragó M, Formentini L, MartínezReyes I, García-Bermudez J, Santacatterina F, Sánchez-Cenizo L, Willers IM, Aldea M, Nájera L, Juarránz A, López EC, Clofent J, Navarro C, Espinosa E, Cuezva JM. Expression, regulation and clinical relevance of the ATPase inhibitory factor 1 in human cancers. Oncogenesis. 2013 Apr 22;2:e46.

243. Zheng J. Energy metabolism of cancer: Glycolysis versus oxidative phosphorylation (Review). Oncol Lett. 2012 Dec;4(6):11511157.

244. Hsu PP, Sabatini DM. Cancer cell metabolism: Warburg and beyond. Cell. 2008;134(5):703-7.

245. Koppenol WH, Bounds PL, Dang CV. Otto Warburg's contributions to current concepts of cancer metabolism. Nat Rev Cancer. 2011;11(5):325-37.

246. Eble KS, Coleman WB, Hantgan RR, Cunningham CC. Tightly associated cardiolipin in the bovine heart mitochondrial ATP synthase as analyzed by $31 \mathrm{P}$ nuclear magnetic resonance spectroscopy. J Biol Chem. 1990 Nov 15;265(32):19434-40.

247. Zhou M, Morgner N, Barrera NP, Politis A, Isaacson SC, Matak-Vinković D, Murata T, Bernal RA, Stock D, Robinson CV. Mass spectrometry of intact V-type ATPases reveals bound lipids and the effects of nucleotide binding. Science. 2011 Oct 21;334(6054):380-5.

248. Cornelius F, Habeck M, Kanai R, Toyoshima C, Karlish SJ. General and specific lipid-protein interactions in Na,K-ATPase. Biochim Biophys Acta. 2015 Mar 16. pii: S0005-2736(15)000917.

249. Yasuda M, Tanaka Y, Kume S, Morita Y, ChinKanasaki M, Araki H, Isshiki K, Araki S, Koya D, Haneda M, Kashiwagi A, Maegawa H, Uzu T. Fatty acids are novel nutrient factors to regulate mTORC1 lysosomal localization and apoptosis in podocytes. Biochim Biophys Acta. 2014;1842(7):1097-108.

250. Li S, Zhou T, Li C, Dai Z, Che D, Yao Y, Li L, Ma J, Yang X, Gao G. High metastaticgastric and breast cancer cells consume oleic acid in an AMPK dependent manner. PLoS One. 2014 May 13;9(5):e97330.

251. Doronzo G, Viretto M, Barale C, Russo I, Mattiello L, Anfossi G, Trovati M. Oleic acid increases synthesis and secretion of VEGF in rat vascular smooth muscle cells: role of oxidative stress and impairment in obesity. Int J Mol Sci. 2013;14(9):18861-80.

252. Georgiadi A, Kersten S. Mechanisms of gene regulation by fatty acids. Adv Nutr. 2012;3(2):127-34.

253. Comba A, Lin YH, Eynard AR, Valentich MA, Fernandez-Zapico ME, Pasqualini ME. Basic aspects of tumor cell fatty acid-regulated signaling and transcription factors. Cancer Metastasis Rev. 2011 Dec;30(3-4):325-42.

254. Coll T, Eyre E, Rodríguez-Calvo R, Palomer X, Sánchez RM, Merlos M, Laguna JC, VázquezCarrera M. Oleate reverses palmitate-induced insulin resistance and inflammation in skeletal muscle cells. J Biol Chem. 2008;283(17):1110716.

255. Costanzi S, Neumann S, Gershengorn MC. Seven transmembrane-spanning receptors for free fatty acids as therapeutic targets for diabetes mellitus: pharmacological, phylogenetic, and drug discovery aspects. J Biol Chem. 2008 Jun 13;283(24):16269-73.

256. Fujiwara K, Maekawa F, Yada T. Oleic acid interacts with GPR40 to induce $\mathrm{Ca} 2+$ signaling in rat islet beta-cells: mediation by PLC and Ltype $\mathrm{Ca} 2+$ channel and link to insulin release. Am J Physiol Endocrinol Metab. 2005;289(4):E670-7.

257. Menendez JA, Mehmi I, Atlas E, Colomer R, Lupu R. Novel signaling molecules implicated in tumor-associated fatty acid synthasedependent breast cancer cell proliferation and survival: Role of exogenous dietary fatty acids, p53-p21WAF1/CIP1, ERK1/2 MAPK, p27KIP1, BRCA1, and NF-kappaB. Int J Oncol. 2004;24(3):591-608.

258. Hajri T, Abumrad NA. Fatty acid transport across membranes: relevance to nutrition and metabolic pathology. Annu Rev Nutr. 2002;22:383-415.

259. Strehler EE, Zacharias DA. Role of alternative splicing in generating isoform diversity among plasma membrane calcium pumps. Physiol Rev. 2001 Jan;81(1):21-50.

260. Tiwari AK, Sodani K, Dai CL, Ashby CR Jr, Chen ZS. Revisiting the ABCs of multidrug resistance in cancer chemotherapy. Curr Pharm Biotechnol. 2011;12(4):570-94.

261. Longley DB, Johnston PG. Molecular mechanisms of drug resistance. J Pathol. 2005 Jan;205(2):275-92.

262. Mantovani I, Cappellini A, Tazzari PL, Papa V, Cocco L, Martelli AM. Caspase-dependent cleavage of $170-\mathrm{kDa}$ P-glycoprotein during apoptosis of human T-lymphoblastoid CEM cells. J Cell Physiol. 2006 Jun;207(3):836-44.

263. Aller SG, Yu J, Ward A, Weng Y, Chittaboina S, Zhuo R, Harrell PM, Trinh YT, Zhang Q, Urbatsch IL, Chang G. Structure of Pglycoprotein reveals a molecular basis for polyspecific drug binding. Science. 2009 Mar 
27;323(5922):1718-22.

264. Siddik ZH. Cisplatin: mode of cytotoxic action and molecular basis of resistance. Oncogene. 2003 Oct 20;22(47):7265-79.

265. Antal O, Hackler L Jr, Shen J, Mán I, Hideghéty K, Kitajka K, Puskás LG. Combination of unsaturated fatty acids and ionizing radiation on human glioma cells: cellular, biochemical and gene expression analysis. Lipids Health Dis. 2014 Sep 2;13:142.

266. Cai F, Sorg O, Granci V, Lecumberri E, Miralbell R, Dupertuis YM, Pichard C. Interaction of $\omega-3$ polyunsaturated fatty acids with radiation therapy in two different colorectal cancer cell lines. Clin Nutr. 2014 Feb;33(1):16470.

267. Yaddanapudi K, Mitchell RA, Eaton JW. Cancer vaccines: Looking to the future. Oncoimmunology. 2013 Mar 1;2(3):e23403.

268. Ota K, Kurita S, Nishimura M, Ogawa M, Kamei Y, Imai K, Ariyoshi Y, Kataoka K, Murakami M, Oyama A, Hoshino A, Amo H, Kato T. Combination therapy with mitomycin C (NSC-26980), 5-fluorouracil (NSC-19893), and cytosine arabinoside (NSC-63878) for advanced cancer in man. Cancer Chemother Rep. 1972 Jun;56(3):373-85.

269. Li WP, Liu H, Chen L, Yao YQ, Zhao EF. A clinical Comparison of Lobaplatin or Cisplatin with Mitomycine and Vincristine in Treating Patients with Cervical Squamous Carcinoma. Asian Pac J Cancer Prev. 2015;16(11):4629-31.

270. Whiteside TL. Immune suppression in cancer: effects on immune cells, mechanisms and future therapeutic intervention. Semin Cancer Biol. 2006 Feb;16(1):3-15.

271. Bracci L, Schiavoni G, Sistigu A, Belardelli F. Immune-based mechanisms of cytotoxic chemotherapy: implications for the design of novel and rationale-based combined treatments against cancer. Cell Death Differ. 2014 Jan;21(1):15-25.
272. Chapman JR, Webster AC, Wong G. Cancer in the transplant recipient. Cold Spring Harb Perspect Med. 2013 Jul 1;3(7).

273. Lipson EJ, Bodell MA, Kraus ES, Sharfman WH. Successful administration of ipilimumab to two kidney transplantation patients with metastatic melanoma. J Clin Oncol. 2014 Jul 1;32(19):e69-71.

274. Kelesidis T, Daikos G, Boumpas D, Tsiodras S. Does rituximab increase the incidence of infectious complications? A narrative review. Int J Infect Dis. 2011 Jan;15(1):e2-16.

275. Theisen-Toupal J, Rosenthal ES, Kelly E, Zwicker JI, Akuthota P, Roberts DH. Pulmonary zygomycosis in a non-neutropenic patient with myelodysplastic syndrome on lenalidomide. Respir Care. 2012 Jul;57(7):1175-7.

276. Brusa D, Simone M, Gontero P, Spadi R, Racca P, Micari J, Degiuli M, Carletto S, Tizzani A, Matera L. Circulating immunosuppressive cells of prostate cancer patients before and after radical prostatectomy: profile comparison. Int $\mathrm{J}$ Urol. 2013 Oct;20(10):971-8.

277. Hanigan MH, Devarajan P. Cisplatin nephrotoxicity: molecular mechanisms. Cancer Ther. 2003;1:47-61.

278. Luger K, Mäder AW, Richmond RK, Sargent DF, Richmond TJ. Crystal structure of the nucleosome core particle at 2.8 A resolution. Nature. 1997 Sep 18;389(6648):251-60.

279. Lu M, Lawrence DA, Marsters S, Acosta-Alvear D, Kimmig P, Mendez AS, Paton AW, Paton JC, Walter P, Ashkenazi A. Opposing unfoldedprotein-response signals converge on death receptor 5 to control apoptosis. Science. 2014 Jul 4;345(6192):98-101.

280. Marks LR, Clementi EA, Hakansson AP. The human milk protein-lipid complex HAMLET sensitizes bacterial pathogens to traditional antimicrobial agents. PLoS One. 2012;7(8):e43514. 


\section{Supplementary information for Structure and potential cellular targets of HAMLET-like anti-cancer compounds made from milk components}

\section{Rath EM, Duff AP, Håkansson AP, Vacher CS, Liu GJ, Knott RB, Church WB}

Supplementary Table 1. Cytotoxicity of HAMLET-like compounds to various cell lines and cell types. The 50\% lethal dose $\left(\mathrm{LD}_{50}\right)$ values (without standard error) from the references are quoted where they were published or were otherwise visually read from the published graphs. The differences in values from different papers, for the same cells, are due to differences in oleate content of the HAMLET-like species prepared by different research groups and due to differences in experimental parameters. The experiments generally involved removing serum during the period of incubation of the cells with the HAMLET-like compound. Concentrations are for the protein component and not the fatty acid anion component. Interconversion calculations from $\mathrm{mg} / \mathrm{ml}$ to $\mu \mathrm{M}$ used molecular weights of $14,078 \mathrm{Da}$ for HAMLET, 14,186 Da for BAMLET, and 18,281 Da for bovine $\beta$-lactoglobulin BAMLET.

\begin{tabular}{|c|c|c|c|}
\hline Cells & Type & Compound & $\begin{array}{c}\mathbf{L D}_{\mathbf{5 0}} \text { or effect } \\
\text { (will be referenced by number } \\
\text { in final draft) }\end{array}$ \\
\hline \multicolumn{4}{|l|}{ Carcinomas and papillomas } \\
\hline \multirow[t]{6}{*}{ A549, human lung carcinoma } & cancerous & HAMLET & $\begin{array}{l}1.25 \mathrm{mg} / \mathrm{ml}, 89 \mu \mathrm{M} \\
\text { (Svanborg et al. } 2003, \\
\text { Gustafsson et al. } 2009 \text { ) }\end{array}$ \\
\hline & & HAMLET & $\begin{array}{l}0.3 \mathrm{mg} / \mathrm{ml}, 20 \mu \mathrm{M} \\
\text { (Hallgren et al. 2006) }\end{array}$ \\
\hline & & $\begin{array}{l}\text { recombinant His-tagged } \\
\text { HAMLET }\end{array}$ & $\begin{array}{l}0.2 \mathrm{mg} / \mathrm{ml}, 14 \mu \mathrm{M} \\
\text { (Zhang et al. 2013) }\end{array}$ \\
\hline & & HAMLET & $\begin{array}{l}0.5 \mathrm{mg} / \mathrm{ml}, 3 \mu \mathrm{M} \\
\text { (Storm et al. 2013, Ho et al. } \\
2013 \text { ) }\end{array}$ \\
\hline & & HAMLET & $\begin{array}{l}\text { 0\% viable at } 10 \mathrm{mg} / \mathrm{ml} \\
\text { (Håkansson et al. 1995) }\end{array}$ \\
\hline & & BAMLET & $\begin{array}{l}7 \% \text { viable at } 1.7 \mathrm{mg} / \mathrm{ml}, 117 \\
\mu \mathrm{M} \text { (Delgado et al. } 2015 \text { ) }\end{array}$ \\
\hline \multirow[t]{2}{*}{ NCI-H292, human bronchial carcinoma } & cancerous & HAMLET & $\begin{array}{l}1 \mathrm{mg} / \mathrm{ml}, 71 \mu \mathrm{M} \\
\text { (Svanborg et al. 2003) }\end{array}$ \\
\hline & & HAMLET & $\begin{array}{l}\text { 0\% viable at } 10 \mathrm{mg} / \mathrm{ml} \\
\text { (Håkansson et al. 1995) }\end{array}$ \\
\hline \multirow[t]{2}{*}{ A498, human kidney carcinoma } & cancerous & HAMLET & $\begin{array}{l}1 \mathrm{mg} / \mathrm{ml}, 71 \mu \mathrm{M} \\
\text { (Svanborg et al. 2003, } \\
\text { Gustafsson et al. 2009) }\end{array}$ \\
\hline & & HAMLET & $\begin{array}{l}5 \% \text { viable at } 10 \mathrm{mg} / \mathrm{ml} \\
\text { (Håkansson et al. 1995) }\end{array}$ \\
\hline $\begin{array}{l}\text { A498, human kidney carcinoma, transfected to } \\
\text { upregulate Bcl-xl }\end{array}$ & cancerous & HAMLET & $\begin{array}{l}0.2 \mathrm{mg} / \mathrm{ml}, 14 \mu \mathrm{M} \\
\text { (Hallgren et al. 2006) }\end{array}$ \\
\hline \multirow[t]{4}{*}{$\mathrm{CaCO} 2$, human intestine carcinoma } & cancerous & HAMLET & $\begin{array}{l}0.55 \mathrm{mg} / \mathrm{ml}, 39 \mu \mathrm{M} \\
\text { (Svanborg et al. } 2003 \text { ) }\end{array}$ \\
\hline & & BAMLET & $\begin{array}{l}1 \mathrm{mg} / \mathrm{ml}, 70 \mu \mathrm{M} \\
\text { (Brinkmann et al. 2011) }\end{array}$ \\
\hline & & BAMLET & $\begin{array}{l}<0.4 \mathrm{mg} / \mathrm{ml},<30 \mu \mathrm{M} \\
\text { (Fang et al. 2012) }\end{array}$ \\
\hline & & HAMLET & $\begin{array}{l}\text { 0\% viable at } 10 \mathrm{mg} / \mathrm{ml} \\
\text { (Håkansson et al. 1995) }\end{array}$ \\
\hline HT29, human intestine carcinoma & cancerous & HAMLET & $\begin{array}{l}1.25 \mathrm{mg} / \mathrm{ml}, 89 \mu \mathrm{M} \\
\text { (Svanborg et al. 2003) }\end{array}$ \\
\hline
\end{tabular}


J Pharm Pharm Sci (www.cspsCanada.org) 18(4) 773 - 824, 2015

\begin{tabular}{|c|c|c|c|}
\hline & & BAMLET & $\begin{array}{l}<0.4 \mathrm{mg} / \mathrm{ml},<30 \mu \mathrm{M} \\
\text { (Fang et al. 2012) }\end{array}$ \\
\hline & & HAMLET & $\begin{array}{l}6 \% \text { viable at } 10 \mathrm{mg} / \mathrm{ml} \\
\text { (Håkansson et al. 1995) }\end{array}$ \\
\hline \multirow[t]{5}{*}{ MCF7, human breast adenocarcinoma } & cancerous & HAMLET & $\begin{array}{l}1.25 \mathrm{mg} / \mathrm{ml}, 89 \mu \mathrm{M} \\
\text { (Svanborg et al. 2003) }\end{array}$ \\
\hline & & BAMLET & $\begin{array}{l}<0.4 \mathrm{mg} / \mathrm{ml},<30 \mu \mathrm{M} \\
\text { (Fang et al. 2012) }\end{array}$ \\
\hline & & BAMLET & $\begin{array}{l}0.09 \mathrm{mg} / \mathrm{ml}, 6 \mu \mathrm{M} \\
(\text { Rammer et al. 2010) }\end{array}$ \\
\hline & & $\beta$-lactoglobulin BAMLET & $\begin{array}{l}1.6 \mathrm{mg} / \mathrm{ml}, 90 \mu \mathrm{M} \\
\text { (Fang et al. 2015) }\end{array}$ \\
\hline & & $\begin{array}{c}\beta \text {-lactoglobulin BAMLET with } \\
\text { linoleic acid }\end{array}$ & $\begin{array}{l}1 \mathrm{mg} / \mathrm{ml}, 60 \mu \mathrm{M} \\
\text { (Fang et al. 2015) }\end{array}$ \\
\hline SK-BR-3, human breast adenocarcinoma & cancerous & HAMLET & $\begin{array}{l}1.25 \mathrm{mg} / \mathrm{ml}, 89 \mu \mathrm{M} \\
\text { (Svanborg et al. 2003) }\end{array}$ \\
\hline MBD-231, human breast adenocarcinoma & cancerous & HAMLET & $\begin{array}{l}1.25 \mathrm{mg} / \mathrm{ml}, 89 \mu \mathrm{M} \\
\text { (Svanborg et al. 2003) }\end{array}$ \\
\hline T47d, human breast ductal carcinoma & cancerous & HAMLET & $\begin{array}{l}1.25 \mathrm{mg} / \mathrm{ml}, 89 \mu \mathrm{M} \\
\text { (Svanborg et al. 2003) }\end{array}$ \\
\hline MBD-175VII, human breast carcinoma & cancerous & HAMLET & $\begin{array}{l}1.5 \mathrm{mg} / \mathrm{ml}, 107 \mu \mathrm{M} \\
\text { (Svanborg et al. 2003) }\end{array}$ \\
\hline \multirow[t]{3}{*}{ PC3, human prostate adenocarcinoma } & cancerous & HAMLET & $\begin{array}{l}1 \mathrm{mg} / \mathrm{ml}, 71 \mu \mathrm{M} \\
\text { (Svanborg et al. 2003) }\end{array}$ \\
\hline & & HAMLET & $\begin{array}{l}0.17 \mathrm{mg} / \mathrm{ml}, 12 \mu \mathrm{M} \\
\text { (Rammer et al. 2010) }\end{array}$ \\
\hline & & BAMLET & $\begin{array}{l}0.23 \mathrm{mg} / \mathrm{ml}, 16 \mu \mathrm{M} \\
\text { (Rammer et al. 2010) }\end{array}$ \\
\hline \multirow[t]{2}{*}{ DU145, human prostate carcinoma } & cancerous & HAMLET & $\begin{array}{l}1.25 \mathrm{mg} / \mathrm{ml}, 89 \mu \mathrm{M} \\
\text { (Svanborg et al. 2003) }\end{array}$ \\
\hline & & camel HAMLET & $\begin{array}{l}0.6 \mathrm{mg} / \mathrm{ml}, 4 \mu \mathrm{M} \\
\text { (Atri et al. 2011) }\end{array}$ \\
\hline WEHI-164, mouse fibrosarcoma & cancerous & HAMLET & $\begin{array}{l}0.75 \mathrm{mg} / \mathrm{ml}, 53 \mu \mathrm{M} \\
\text { (Svanborg et al. 2003) }\end{array}$ \\
\hline HCT116, human colon carcinoma & cancerous & HAMLET & $\begin{array}{l}0.6 \mathrm{mg} / \mathrm{ml}, 40 \mu \mathrm{M} \\
\text { (Svanborg et al. 2003) }\end{array}$ \\
\hline HCT116, human colon carcinoma, p53 wildtype & cancerous & HAMLET & $\begin{array}{l}0.7 \mathrm{mg} / \mathrm{ml}, 48 \mu \mathrm{M} \\
\text { (Hallgren et al. 2006) }\end{array}$ \\
\hline HCT116, human colon carcinoma, p53 deletion & cancerous & HAMLET & $\begin{array}{l}0.7 \mathrm{mg} / \mathrm{ml}, 44 \mu \mathrm{M} \\
\text { (Hallgren et al. 2006) }\end{array}$ \\
\hline \multirow[t]{2}{*}{ H1299, human lung carcinoma } & cancerous & HAMLET & $\begin{array}{l}0.7 \mathrm{mg} / \mathrm{ml}, 50 \mu \mathrm{M} \\
\text { (Svanborg et al. 2003) }\end{array}$ \\
\hline & & $\begin{array}{l}\text { recombinant His-tagged } \\
\text { HAMLET }\end{array}$ & $\begin{array}{l}0.07 \mathrm{mg} / \mathrm{ml}, 5 \mu \mathrm{M} \\
\text { (Zhang et al. 2013) }\end{array}$ \\
\hline H1299, human lung carcinoma, p53 deletion & cancerous & HAMLET & $\begin{array}{l}0.6 \mathrm{mg} / \mathrm{ml}, 42 \mu \mathrm{M} \\
\text { (Hallgren et al. 2006) }\end{array}$ \\
\hline $\begin{array}{l}\text { H1299, human lung carcinoma, p53 His-175 gain of } \\
\text { function }\end{array}$ & cancerous & HAMLET & $\begin{array}{l}0.6 \mathrm{mg} / \mathrm{ml}, 42 \mu \mathrm{M} \\
\text { (Hallgren et al. 2006) }\end{array}$ \\
\hline Skov3, human ovarian carcinoma & cancerous & BAMLET & $\begin{array}{l}0.2 \mathrm{mg} / \mathrm{ml}, 14 \mu \mathrm{M} \\
\text { (Brinkmann et al. 2011) }\end{array}$ \\
\hline MB49, mouse bladder carcinoma & cancerous & HAMLET & $\begin{array}{l}0.2 \mathrm{mg} / \mathrm{ml}, 14 \mu \mathrm{M} \\
\text { (Mossberg 2010) }\end{array}$ \\
\hline \multirow[t]{2}{*}{ HeLa, human cervical epithelial adenocarcinoma } & cancerous & HAMLET & $\begin{array}{l}0.2 \mathrm{mg} / \mathrm{ml}, 14 \mu \mathrm{M} \\
(\text { Rammer et al. 2010) }\end{array}$ \\
\hline & & BAMLET & $\begin{array}{l}0.12 \mathrm{mg} / \mathrm{ml}, 8 \mu \mathrm{M} \\
(\text { Rammer et al. } 2010)\end{array}$ \\
\hline
\end{tabular}


J Pharm Pharm Sci (www.cspsCanada.org) 18(4) 773 - 824, 2015

\begin{tabular}{|c|c|c|c|}
\hline & & BAMLET & $\begin{array}{l}10 \% \text { viable at } 1.7 \mathrm{mg} / \mathrm{ml}, 117 \\
\mu \mathrm{M} \text { (Delgado et al. } 2015)\end{array}$ \\
\hline & & $\beta$-lactoglobulin BAMLET & $\begin{array}{l}2 \mathrm{mg} / \mathrm{ml}, 110 \mu \mathrm{M} \\
\text { (Fang et al. 2015) }\end{array}$ \\
\hline & & $\begin{array}{c}\beta \text {-lactoglobulin BAMLET with } \\
\text { linoleic acid }\end{array}$ & $\begin{array}{l}1 \mathrm{mg} / \mathrm{ml}, 60 \mu \mathrm{M} \\
\text { (Fang et al. 2015) }\end{array}$ \\
\hline \multirow[t]{4}{*}{ HEp2, human epidermoid larynx carcinoma } & cancerous & HAMLET & $\begin{array}{l}0.028 \mathrm{mg} / \mathrm{ml}, 2 \mu \mathrm{M} \\
\text { (Permyakov et al. 2012) }\end{array}$ \\
\hline & & BAMLET & $\begin{array}{l}0.022 \mathrm{mg} / \mathrm{ml}, 2 \mu \mathrm{M} \\
\text { (Permyakov et al. 2012) }\end{array}$ \\
\hline & & $\begin{array}{l}\beta \text {-lactoglobulin } \\
\text { BAMLET }\end{array}$ & $\begin{array}{l}0.011 \mathrm{mg} / \mathrm{ml}, 1 \mu \mathrm{M} \\
\text { (Permyakov et al. 2012) }\end{array}$ \\
\hline & & $\begin{array}{l}\text { parvalbumin } \\
\text { HAMLET }\end{array}$ & $\begin{array}{l}0.015 \mathrm{mg} / \mathrm{ml}, 1 \mu \mathrm{M} \\
\text { (Permyakov et al. 2012) }\end{array}$ \\
\hline \multirow[t]{4}{*}{$\mathrm{J} 82$, human bladder transitional cell carcinoma } & cancerous & HAMLET & $\begin{array}{l}0.75 \mathrm{mg} / \mathrm{ml}, 53 \mu \mathrm{M} \\
\text { (Svanborg et al. } 2003 \text { ) }\end{array}$ \\
\hline & & HAMLET & $\begin{array}{l}0.27 \mathrm{mg} / \mathrm{ml}, 19 \mu \mathrm{M} \\
\text { (Rammer et al. } 2010 \text { ) }\end{array}$ \\
\hline & & BAMLET & $\begin{array}{l}0.15 \mathrm{mg} / \mathrm{ml}, 11 \mu \mathrm{M} \\
\text { (Rammer et al. 2010) }\end{array}$ \\
\hline & & HAMLET & $\begin{array}{l}4 \% \text { viable at } 10 \mathrm{mg} / \mathrm{ml} \\
\text { (Håkansson et al. 1995) }\end{array}$ \\
\hline \multirow[t]{2}{*}{ HTB9, human bladder carcinoma } & cancerous & BAMLET & $\begin{array}{l}0.15 \mathrm{mg} / \mathrm{ml}, 11 \mu \mathrm{M} \text { (Xiao et } \\
\text { al. } 2013 \text { ) }\end{array}$ \\
\hline & & HAMLET & $\begin{array}{l}4 \% \text { viable at } 10 \mathrm{mg} / \mathrm{ml} \\
\text { (Håkansson et al. 1995) }\end{array}$ \\
\hline UMUC3, human bladder urothelial cancer & cancerous & BAMLET & $\begin{array}{l}0.13 \mathrm{mg} / \mathrm{ml}, 9 \mu \mathrm{M} \text { (Xiao et al. } \\
2013 \text { ) }\end{array}$ \\
\hline UMUC6, human bladder urothelial cancer & cancerous & BAMLET & $\begin{array}{l}0.34 \mathrm{mg} / \mathrm{ml}, 24 \mu \mathrm{M} \text { (Xiao et } \\
\text { al. 2013) }\end{array}$ \\
\hline UMUC9, human bladder urothelial cancer & cancerous & BAMLET & $\begin{array}{l}0.8 \mathrm{mg} / \mathrm{ml}, 56 \mu \mathrm{M} \text { (Xiao et al. } \\
2013 \text { ) }\end{array}$ \\
\hline T24, human bladder urothelial cancer & cancerous & BAMLET & $\begin{array}{l}0.35 \mathrm{mg} / \mathrm{ml}, 25 \mu \mathrm{M} \text { (Xiao et } \\
\text { al. 2013) }\end{array}$ \\
\hline $\begin{array}{l}253 \mathrm{~J}, \text { human metastatic bladder urothelial transitional } \\
\text { cell carcinoma }\end{array}$ & cancerous & BAMLET & $\begin{array}{l}0.15 \mathrm{mg} / \mathrm{ml}, 11 \mu \mathrm{M} \text { (Xiao et } \\
\text { al. } 2013 \text { ) }\end{array}$ \\
\hline MGH-U3, human bladder urinary tract carcinoma & cancerous & BAMLET & $\begin{array}{l}0.35 \mathrm{mg} / \mathrm{ml}, 25 \mu \mathrm{M} \text { (Xiao et } \\
\text { al. 2013) }\end{array}$ \\
\hline $\begin{array}{l}\text { RT112, human differentiated urinary bladder } \\
\text { transitional cell carcinoma }\end{array}$ & cancerous & BAMLET & $\begin{array}{l}0.4 \mathrm{mg} / \mathrm{ml}, 28 \mu \mathrm{M} \text { (Xiao et al. } \\
2013 \text { ) }\end{array}$ \\
\hline $\begin{array}{l}\text { TRAIL-resistant UMUC14, human bladder epithelial } \\
\text { carcinoma }\end{array}$ & cancerous & BAMLET & $\begin{array}{l}0.28 \mathrm{mg} / \mathrm{ml}, 20 \mu \mathrm{M} \text { (Xiao et } \\
\text { al. } 2013 \text { ) }\end{array}$ \\
\hline $\begin{array}{l}\text { TRAIL-resistant HT1376, human urinary bladder } \\
\text { epithelial carcinoma }\end{array}$ & cancerous & BAMLET & $\begin{array}{l}0.47 \mathrm{mg} / \mathrm{ml}, 33 \mu \mathrm{M} \text { (Xiao et } \\
\text { al. } 2013 \text { ) }\end{array}$ \\
\hline AY27, rat bladder urothelial cancer & cancerous & BAMLET & $\begin{array}{l}0.2 \mathrm{mg} / \mathrm{ml}, 14 \mu \mathrm{M} \text { (Xiao et al. } \\
2013 \text { ) }\end{array}$ \\
\hline \multirow[t]{3}{*}{ RT4, human bladder transitional cell papilloma } & cancerous & HAMLET & $\begin{array}{l}0.44 \mathrm{mg} / \mathrm{ml}, 31 \mu \mathrm{M} \\
(\text { Rammer et al. } 2010)\end{array}$ \\
\hline & & BAMLET & $\begin{array}{l}0.32 \mathrm{mg} / \mathrm{ml}, 23 \mu \mathrm{M} \\
\text { (Rammer et al. } 2010)\end{array}$ \\
\hline & & BAMLET & $\begin{array}{l}0.5 \mathrm{mg} / \mathrm{ml}, 35 \mu \mathrm{M} \text { (Xiao et al. } \\
2013)\end{array}$ \\
\hline \multicolumn{4}{|l|}{ Pheochromocytomas, osteosarcomas, and melanoma } \\
\hline PC12, rat adrenal pheochromocytoma, & cancerous & BAMLET & $0.09-0.16 \mathrm{mg} / \mathrm{ml}, 6-11 \mu \mathrm{M}$ \\
\hline
\end{tabular}


J Pharm Pharm Sci (www.cspsCanada.org) 18(4) 773 - 824, 2015

\begin{tabular}{|c|c|c|c|}
\hline \multicolumn{3}{|l|}{ undifferentiated state } & \multirow{2}{*}{$\begin{array}{l}\text { (depending on oleate content) } \\
\text { (Lišková et al. 2011) } \\
0.2-1 \mathrm{mg} / \mathrm{ml}, 10-55 \mu \mathrm{M} \\
\text { (depending on oleate content) } \\
\text { (Lišková et al. 2011) }\end{array}$} \\
\hline & & $\begin{array}{l}\beta \text {-lactoglobulin } \\
\text { BAMLET }\end{array}$ & \\
\hline $\begin{array}{l}\text { PC12, rat adrenal pheochromocytoma, differentiated } \\
\text { state }\end{array}$ & cancerous & BAMLET & $\begin{array}{l}0.47-0.60 \mathrm{mg} / \mathrm{ml}, 33-42 \mu \mathrm{M} \\
\text { (depending on oleate content) } \\
\text { (Lišková et al. 2011) }\end{array}$ \\
\hline & & $\begin{array}{l}\beta \text {-lactoglobulin } \\
\text { BAMLET }\end{array}$ & $\begin{array}{l}0.02-0.2 \mathrm{mg} / \mathrm{ml}, 1-10 \mu \mathrm{M} \\
\text { (depending on oleate content) } \\
\text { (Lišková et al. 2011) }\end{array}$ \\
\hline PC12, rat adrenal pheochromocytoma & cancerous & ELOA & $\begin{array}{l}\text { visualised cell death at } 0.0035 \\
\mathrm{mg} / \mathrm{ml}, 0.24 \mu \mathrm{M}, 61 \mathrm{mins} \\
\text { (Vukojević et al. 2010) }\end{array}$ \\
\hline \multirow[t]{2}{*}{ U2OS, human bone osteosarcoma } & cancerous & BAMLET & $\begin{array}{l}0.06 \mathrm{mg} / \mathrm{ml}, 4 \mu \mathrm{M} \\
\text { (Rammer et al. 2010) }\end{array}$ \\
\hline & & HAMLET & $\begin{array}{l}0.075 \mathrm{mg} / \mathrm{ml}, 5 \mu \mathrm{M} \\
\text { (Xie et al. 2013) }\end{array}$ \\
\hline B16F0, mouse non-metastatic melanoma & cancerous & BAMLET & $\begin{array}{l}0.29 \mathrm{mg} / \mathrm{ml}, 20 \mu \mathrm{M} \\
\text { (Brinkmann et al. 2011) }\end{array}$ \\
\hline \multicolumn{4}{|l|}{ Gliomas } \\
\hline U37, human glioma & cancerous & HAMLET & $\begin{array}{l}2 \mathrm{mg} / \mathrm{ml}, 117 \mu \mathrm{M} \\
\text { (Svanborg et al. 2003) }\end{array}$ \\
\hline U251 human glioma & cancerous & HAMLET & $\begin{array}{l}0.4 \mathrm{mg} / \mathrm{ml}, 30 \mu \mathrm{M} \text { (Svanborg } \\
\text { et al. 2003, Fischer et al. } \\
\text { 2004) }\end{array}$ \\
\hline CRL2356 human glioma & cancerous & HAMLET & $\begin{array}{l}0.4 \mathrm{mg} / \mathrm{ml}, 30 \mu \mathrm{M} \text { (Svanborg } \\
\text { et al. 2003, Fischer et al. } \\
2004 \text { ) }\end{array}$ \\
\hline \multirow[t]{2}{*}{ U118, human glioblastoma } & cancerous & HAMLET & $\begin{array}{l}0.40 \mathrm{mg} / \mathrm{ml}, 28 \mu \mathrm{M} \\
\text { (Rammer et al. 2010) }\end{array}$ \\
\hline & & BAMLET & $\begin{array}{l}0.34 \mathrm{mg} / \mathrm{ml}, 24 \mu \mathrm{M} \\
\text { (Rammer et al. 2010) }\end{array}$ \\
\hline U87MG, human glioma & cancerous & $\begin{array}{l}\text { recombinant His-tagged } \\
\text { HAMLET }\end{array}$ & $\begin{array}{l}0.1 \mathrm{mg} / \mathrm{ml}, 7 \mu \mathrm{M} \\
\text { (Zhang et al. 2013) }\end{array}$ \\
\hline BT4C, mouse glioma & cancerous & HAMLET & $\begin{array}{l}0.5 \mathrm{mg} / \mathrm{ml}, 36 \mu \mathrm{M} \text { (Svanborg } \\
\text { et al. 2003) }\end{array}$ \\
\hline \multicolumn{4}{|l|}{ Lymphomas and leukaemias } \\
\hline \multirow[t]{5}{*}{ U937, human monocyte, histiocytic lymphoma } & cancerous & HAMLET & $\begin{array}{l}0.5 \mathrm{mg} / \mathrm{ml}, 36 \mu \mathrm{M} \text { (Svanborg } \\
\text { et al. 2003) }\end{array}$ \\
\hline & & BAMLET & $\begin{array}{l}0.06 \mathrm{mg} / \mathrm{ml}, 2 \mu \mathrm{M} \\
\text { (Brinkmann et al. 2011) }\end{array}$ \\
\hline & & BAMLET & $\begin{array}{l}0.2 \mathrm{mg} / \mathrm{ml}, 34 \mu \mathrm{M} \\
\text { (Lišková et al. } 2010 \text { ) }\end{array}$ \\
\hline & & BAMLET & $\begin{array}{l}0.3-0.5 \mathrm{mg} / \mathrm{ml}, 20-36 \mu \mathrm{M} \\
\text { (depending on oleate content) } \\
\text { (Lišková et al. 2011) }\end{array}$ \\
\hline & & $\begin{array}{l}\beta \text {-lactoglobulin } \\
\text { BAMLET }\end{array}$ & $\begin{array}{l}0.5-1.5 \mathrm{mg} / \mathrm{ml}, 30-80 \mu \mathrm{M} \\
\text { (depending on oleate content) } \\
\text { (Lišková et al. 2011) }\end{array}$ \\
\hline Jurkat, human acute T-cell lymphocytic leukaemia & cancerous & HAMLET & $\begin{array}{l}0.4 \mathrm{mg} / \mathrm{ml}, 28 \mu \mathrm{M} \text { (Svanborg } \\
\text { et al. 2003) }\end{array}$ \\
\hline
\end{tabular}


J Pharm Pharm Sci (www.cspsCanada.org) 18(4) 773 - 824, 2015

\begin{tabular}{|c|c|c|c|}
\hline & & HAMLET & $\begin{array}{l}0.6 \mathrm{mg} / \mathrm{ml}, 46 \mu \mathrm{M} \text { (Hallgren } \\
\text { et al. 2006) }\end{array}$ \\
\hline & & BAMLET & $\begin{array}{l}0.09 \mathrm{mg} / \mathrm{ml}, 6 \mu \mathrm{M} \\
\text { (Brinkmann et al. 2011, } \\
\text { Brinkmann 2013) }\end{array}$ \\
\hline & & HAMLET & $\begin{array}{l}0.3 \mathrm{mg} / \mathrm{ml}, 18 \mu \mathrm{M} \text { (Hallgren } \\
\text { et al. 2006) }\end{array}$ \\
\hline $\begin{array}{l}\text { Jurkat, human acute T-cell lymphocytic leukaemia, } \\
\text { transfected to upregulate Bcl-2 }\end{array}$ & cancerous & HAMLET & $\begin{array}{l}0.3 \mathrm{mg} / \mathrm{ml}, 18 \mu \mathrm{M} \text { (Hallgren } \\
\text { et al. 2006) }\end{array}$ \\
\hline \multirow[t]{4}{*}{ L1210, mouse prolymphocytic leukaemia } & cancerous & HAMLET & $\begin{array}{l}0.5 \mathrm{mg} / \mathrm{ml}, 36 \mu \mathrm{M} \text { (Håkansson } \\
\text { et al. 1999) }\end{array}$ \\
\hline & & HAMLET & $\begin{array}{l}0.3 \mathrm{mg} / \mathrm{ml}, 21 \mu \mathrm{M} \text { (Svanborg } \\
\text { et al. 2003) }\end{array}$ \\
\hline & & HAMLET & $\begin{array}{l}0.05 \mathrm{mg} / \mathrm{ml}, 4 \mu \mathrm{M} \\
\text { (Rammer et al. } 2010 \text { ) }\end{array}$ \\
\hline & & BAMLET & $\begin{array}{l}0.04 \mathrm{mg} / \mathrm{ml}, 3 \mu \mathrm{M} \\
\text { (Rammer et al. 2010) }\end{array}$ \\
\hline B9, mouse lymphocytic leukaemia & cancerous & HAMLET & $\begin{array}{l}0.3 \mathrm{mg} / \mathrm{ml}, 21 \mu \mathrm{M} \text { (Svanborg } \\
\text { et al. 2003) }\end{array}$ \\
\hline \multirow[t]{3}{*}{ HL60, human promyeolcytic leukaemia } & cancerous & HAMLET & $\begin{array}{l}0.5 \mathrm{mg} / \mathrm{ml}, 36 \mu \mathrm{M} \text { (Svanborg } \\
\text { et al. 2003) }\end{array}$ \\
\hline & & BAMLET & $\begin{array}{l}0.03 \mathrm{mg} / \mathrm{ml}, 2 \mu \mathrm{M} \\
\text { (Brinkmann et al. 2011, } \\
\text { Brinkmann 2013) }\end{array}$ \\
\hline & & BAMLET & $\begin{array}{l}0.4 \mathrm{mg} / \mathrm{ml},<30 \mu \mathrm{M} \text { (Fang et } \\
\text { al. 2012) }\end{array}$ \\
\hline \multirow[t]{2}{*}{ K562, human myeolgeneous leukaemia } & cancerous & HAMLET & $\begin{array}{l}0.5 \mathrm{mg} / \mathrm{ml}, 36 \mu \mathrm{M} \text { (Svanborg } \\
\text { et al. 2003) }\end{array}$ \\
\hline & & HAMLET & $\begin{array}{l}0.3 \mathrm{mg} / \mathrm{ml}, 18 \mu \mathrm{M} \text { (Hallgren } \\
\text { et al. 2006) }\end{array}$ \\
\hline $\begin{array}{l}\text { K562, human myeolgeneous leukaemia, transfected to } \\
\text { upregulate Bcl-2 }\end{array}$ & cancerous & HAMLET & $\begin{array}{l}0.3 \mathrm{mg} / \mathrm{ml}, 19 \mu \mathrm{M} \text { (Hallgren } \\
\text { et al. 2006) }\end{array}$ \\
\hline THP1, human monocytic leukaemia & cancerous & BAMLET & $\begin{array}{l}0.1 \mathrm{mg} / \mathrm{ml}, 7 \mu \mathrm{M} \\
\text { (Brinkmann et al. 2011) }\end{array}$ \\
\hline \multirow[t]{2}{*}{ FL5.12, mouse lymphocytic leukaemia } & cancerous & HAMLET & $\begin{array}{l}0.14 \mathrm{mg} / \mathrm{ml}, 10 \mu \mathrm{M} \text { (Svanborg } \\
\text { et al. 2003) }\end{array}$ \\
\hline & & HAMLET & $\begin{array}{l}0.1 \mathrm{mg} / \mathrm{ml}, 9 \mu \mathrm{M} \text { (Hallgren et } \\
\text { al. } 2006)\end{array}$ \\
\hline $\begin{array}{l}\text { FL5.12, mouse lymphocytic leukaemia, transfected to } \\
\text { upregulate Bcl-xl }\end{array}$ & cancerous & HAMLET & $\begin{array}{l}0.1 \mathrm{mg} / \mathrm{ml}, 9 \mu \mathrm{M} \text { (Hallgren et } \\
\text { al. 2006) }\end{array}$ \\
\hline \multicolumn{4}{|l|}{ Non-cancerous immortalised cell lines } \\
\hline GMK, monkey kidney & non-cancerous, immortalised & HAMLET & $\begin{array}{l}1 \mathrm{mg} / \mathrm{ml}, 71 \mu \mathrm{M} \text { (Svanborg et } \\
\text { al. 2003) }\end{array}$ \\
\hline Vero, monkey kidney & non-cancerous, immortalised & HAMLET & $\begin{array}{l}1.75 \mathrm{mg} / \mathrm{ml}, 124 \mu \mathrm{M} \\
\text { (Svanborg et al. } 2003 \text { ) }\end{array}$ \\
\hline MDCK, dog kidney & non-cancerous, immortalised & HAMLET & $\begin{array}{l}0.75 \mathrm{mg} / \mathrm{ml}, 53 \mu \mathrm{M} \text { (Svanborg } \\
\text { et al. 2003) }\end{array}$ \\
\hline \multirow[t]{2}{*}{ NIH-3T3, mouse embryonic fibroblast } & $\begin{array}{l}\text { non-cancerous, } \\
\text { immortalised }\end{array}$ & BAMLET & $\begin{array}{l}>0.4 \mathrm{mg} / \mathrm{ml},>30 \mu \mathrm{M} \\
(75 \% \text { viable at } 0.4 \mathrm{mg} / \mathrm{ml}) \\
(\text { Rammer et al. } 2010)\end{array}$ \\
\hline & & BAMLET & $\begin{array}{l}15 \% \text { viability at } 1.7 \mathrm{mg} / \mathrm{ml}, \\
117 \mu \mathrm{M} \text { (Delgado et al. } 2015 \text { ) }\end{array}$ \\
\hline Cho-K1, Chinese hamster ovary epithelial & non-cancerous & BAMLET & $\begin{array}{l}30 \% \text { viability at } 1.7 \mathrm{mg} / \mathrm{ml}, \\
117 \mu \mathrm{M} \text { (Delgado et al. } 2015 \text { ) }\end{array}$ \\
\hline
\end{tabular}


J Pharm Pharm Sci (www.cspsCanada.org) 18(4) 773 - 824, 2015

\begin{tabular}{|c|c|c|c|}
\hline F2P6, human benign fibroblast & non-cancerous, immortalised & BAMLET & $\begin{array}{l}>0.8 \mathrm{mg} / \mathrm{ml}, 56 \mu \mathrm{M} \text { (resistant } \\
\text { at dose of } 0.8 \mathrm{mg} / \mathrm{ml} \text { that } \\
\text { killed AY27 cancer cells in } \\
\text { same spheroid) (Xiao et al. } \\
2013 \text { ) }\end{array}$ \\
\hline $\begin{array}{l}\text { Human non-transformed astrocytes from manufacturer } \\
\text { CC 2565, Cambrex, La Jolla, CA, USA }\end{array}$ & non-cancerous & HAMLET & $\begin{array}{l}>0.48 \mathrm{mg} / \mathrm{ml},>34 \mu \mathrm{M} \\
\text { (resistant at } 34 \mu \mathrm{M} \text { although } \\
\text { some HAMLET entered cells) } \\
\text { (Gustafsson et al. 2009) }\end{array}$ \\
\hline \multicolumn{4}{|l|}{ Non-cancerous embryonic cells } \\
\hline human embryonic lung & non-cancerous, embryonic & HAMLET & $\begin{array}{l}8 \% \text { viable at } 10 \mathrm{mg} / \mathrm{ml} \\
\text { (Håkansson et al. 1995) }\end{array}$ \\
\hline human embryonic foreskin & non-cancerous, embryonic & HAMLET & $\begin{array}{l}8 \% \text { viable at } 10 \mathrm{mg} / \mathrm{ml} \\
\text { (Håkansson et al. 1995) }\end{array}$ \\
\hline Normal adult human keratinocytes & non-cancerous, primary & BAMLET & $\begin{array}{l}0.1 \mathrm{mg} / \mathrm{ml}, 7 \mu \mathrm{M} \\
\text { (Brinkmann et al. 2011) }\end{array}$ \\
\hline Human umbilical vein endothelial cells (HUVEC) & non-cancerous, primary & BAMLET & $\begin{array}{l}1 \mathrm{mg} / \mathrm{ml}, 70 \mu \mathrm{M} \\
\text { (Brinkmann et al. 2011) }\end{array}$ \\
\hline primary human renal tubular epithelial cells & non-cancerous, primary & HAMLET & $\begin{array}{l}>0.1 \mathrm{mg} / \mathrm{ml},>7 \mu \mathrm{M} \text { (resistant } \\
\text { at } 0.1 \mathrm{mg} / \mathrm{ml} \text { ) (Düringer et al. } \\
2003 \text { ) }\end{array}$ \\
\hline \multirow[t]{2}{*}{ human renal epithelial cells (HRTEC) } & non-cancerous, primary & HAMLET & $\begin{array}{l}>0.48 \mathrm{mg} / \mathrm{ml},>34 \mu \mathrm{M} \\
\text { (resistant at } 34 \mu \mathrm{M} \text { ) } \\
\text { (Gustafsson et al. 2009) }\end{array}$ \\
\hline & & HAMLET & $\begin{array}{l}>4 \mathrm{mg} / \mathrm{ml},>284 \mu \mathrm{M} \\
\text { (remained } 80 \% \text { viable after } 24 \\
\text { h exposure to } 4 \mathrm{mg} / \mathrm{ml} \text { ) } \\
\text { (Håkansson et al. } 1999 \text { ) }\end{array}$ \\
\hline primary mouse brain cells & non-cancerous, primary & HAMLET & $\begin{array}{l}>0.07 \mathrm{mg} / \mathrm{ml},>4 \mu \mathrm{M} \\
(100 \% \text { viable at } 0.07 \mathrm{mg} / \mathrm{ml}) \\
\text { (Fischer et al. } 2004)\end{array}$ \\
\hline primary mouse astrocytes & non-cancerous, primary & $\begin{array}{l}\text { recombinant His-tagged } \\
\text { HAMLET }\end{array}$ & $\begin{array}{l}>0.2 \mathrm{mg} / \mathrm{ml},>14 \mu \mathrm{M} \\
(90 \% \text { viable at } 0.2 \mathrm{mg} / \mathrm{ml}) \\
(\text { Zhang et al. } 2013)\end{array}$ \\
\hline nontransformed human nasopharynx epithelium & non-cancerous, primary & HAMLET & $\begin{array}{l}45 \% \text { viable at } 10 \mathrm{mg} / \mathrm{ml} \\
\text { (Håkansson et al. 1995) }\end{array}$ \\
\hline nontransformed human urinary epithelium & non-cancerous, primary & HAMLET & $\begin{array}{l}75 \% \text { viable at } 10 \mathrm{mg} / \mathrm{ml} \\
\text { (Håkansson et al. 1995) }\end{array}$ \\
\hline nontransformed mouse kidney epithelial & non-cancerous, primary & HAMLET & $\begin{array}{l}62 \% \text { viable at } 10 \mathrm{mg} / \mathrm{ml} \\
\text { (Håkansson et al. 1995) }\end{array}$ \\
\hline nontransformed mouse bladder epithelial & non-cancerous, primary & HAMLET & $\begin{array}{l}48 \% \text { viable at } 10 \mathrm{mg} / \mathrm{ml} \\
\text { (Håkansson et al. 1995) }\end{array}$ \\
\hline mouse adipocytes & non-cancerous, primary & BAMLET & $\begin{array}{l}>0.05 \mathrm{mg} / \mathrm{ml}, 282 \mu \mathrm{M} \\
\text { (resistant at } 4 \mathrm{mg} / \mathrm{ml} \text { dose that } \\
\text { killed cancerous MCF-7 and } \\
\text { Jurkat cell lines) (Hoque et al. } \\
2013 \text { ) }\end{array}$ \\
\hline \multicolumn{4}{|l|}{\begin{tabular}{|l|} 
Non-cancerous primary blood cells \\
\end{tabular}} \\
\hline Peripheral blood mononuclear cells (PBMC) & non-cancerous, primary & BAMLET & $\begin{array}{l}0.02 \mathrm{mg} / \mathrm{ml}, 1 \mu \mathrm{M} \\
\text { (Brinkmann et al. 2011) }\end{array}$ \\
\hline \multirow[t]{2}{*}{ human erythrocytes } & non-cancerous, primary & $\begin{array}{l}\text { BAMLET, BLAGLET, ELOA } \\
\text { parvalbumin HAMLET }\end{array}$ & $\begin{array}{l}0.02 \mathrm{mg} / \mathrm{ml}, 1.4 \mu \mathrm{M},(20 \mu \mathrm{M} \\
\text { oleate) (Kaspersen et al. } 2014)\end{array}$ \\
\hline & & ovalbumin HAMLET & $\begin{array}{l}0.02 \mathrm{mg} / \mathrm{ml}, 0.44 \mu \mathrm{M},(20 \mu \mathrm{M} \\
\text { oleate) (Kaspersen et al. } 2014)\end{array}$ \\
\hline
\end{tabular}


J Pharm Pharm Sci (www.cspsCanada.org) 18(4) 773 - 824, 2015

\begin{tabular}{|c|c|c|c|}
\hline & & immunoglobulin G HAMLET & $\begin{array}{l}0.02 \mathrm{mg} / \mathrm{ml}, 0.13 \mu \mathrm{M},(20 \mu \mathrm{M} \\
\text { oleate) (Kaspersen et al. } 2014)\end{array}$ \\
\hline & & albumin BAMLET & $\begin{array}{l}0.028 \mathrm{mg} / \mathrm{ml}, 0.4 \mu \mathrm{M},(28 \mu \mathrm{M} \\
\text { oleate) (Kaspersen et al. 2014) }\end{array}$ \\
\hline & & BAMLET & $\begin{array}{l}0.6 \mathrm{mg} / \mathrm{ml}, 42 \mu \mathrm{M} \text { (Hoque et } \\
\text { al. 2013) }\end{array}$ \\
\hline mouse erythrocytes & non-cancerous, primary & BAMLET & $\begin{array}{l}0.8 \mathrm{mg} / \mathrm{ml}, 58 \mu \mathrm{M} \text { (Hoque et } \\
\text { al. 2013) }\end{array}$ \\
\hline goat erythrocytes & non-cancerous, primary & BAMLET & $\begin{array}{l}0.7 \mathrm{mg} / \mathrm{ml}, 50 \mu \mathrm{M} \text { (Hoque et } \\
\text { al. 2013) }\end{array}$ \\
\hline rabbit erythrocytes & non-cancerous, primary & BAMLET & $\begin{array}{l}0.6 \mathrm{mg} / \mathrm{ml}, 40 \mu \mathrm{M} \text { (Hoque et } \\
\text { al. 2013) }\end{array}$ \\
\hline buffalo erythrocytes & non-cancerous, primary & BAMLET & $\begin{array}{l}0.4 \mathrm{mg} / \mathrm{ml}, 30 \mu \mathrm{M} \text { (Hoque et } \\
\text { al. 2013) }\end{array}$ \\
\hline chicken erythrocytes & non-cancerous, primary & BAMLET & $\begin{array}{l}\sim 0.6 \mathrm{mg} / \mathrm{ml}, \sim 45 \mu \mathrm{M} \text { (Hoque } \\
\text { et al. } 2015 \text { ) }\end{array}$ \\
\hline nontransformed human granulocytes blood cell & non-cancerous, primary & HAMLET & $\begin{array}{l}62 \% \text { viable at } 10 \mathrm{mg} / \mathrm{ml} \\
\text { (Håkansson et al. } 1995 \text { ) }\end{array}$ \\
\hline nontransformed human lymphocytes blood cell & non-cancerous, primary & HAMLET & $\begin{array}{l}26 \% \text { viable at } 10 \mathrm{mg} / \mathrm{ml} \\
\text { (Håkansson et al. } 1995 \text { ) }\end{array}$ \\
\hline nontransformed rat thymocyte pre-blood cell & non-cancerous, primary & HAMLET & $\begin{array}{l}0 \% \text { viable at } 10 \mathrm{mg} / \mathrm{ml} \\
\text { (Håkansson et al. 1995) }\end{array}$ \\
\hline mouse peritoneal macrophage & non-cancerous, primary & BAMLET & $\begin{array}{l}>0.05 \mathrm{mg} / \mathrm{ml}, 282 \mu \mathrm{M} \\
\text { (resistant at } 4 \mathrm{mg} / \mathrm{ml} \text { dose that } \\
\text { killed cancerous MCF-7 and } \\
\text { Jurkat cell lines) (Hoque et al. } \\
2013 \text { ) }\end{array}$ \\
\hline
\end{tabular}

Supplementary Table 2. Stoichiometry of protein to fatty acid in various HAMLET-like compounds made by various methods and with different protein or fatty acid. Different method types can produce similar amounts of incorporated oleate, and small changes in the parameters of a method type can produce significant differences in the amounts of incorporation of the active ingredient oleate.

\begin{tabular}{|c|c|c|c|c|c|c|}
\hline $\begin{array}{c}\text { Protein: } \\
\text { oleate } \\
\text { stoichiometry }\end{array}$ & $\begin{array}{c}\text { Number of } \\
\text { molecules per } \\
\text { aggregate }\end{array}$ & Species & Protein & $\begin{array}{l}\text { Fatty acid } \\
\text { anion }\end{array}$ & Preparation method & Ref. \\
\hline $1: 0.9 \pm 0.36$ & & HAMLET & human $\alpha$-lactalbumin & oleic acid & column chromatography & $\begin{array}{l}\text { (Svensson et } \\
\text { al. 2000) }\end{array}$ \\
\hline $1: 5.4 \pm 1.5$ & & HAMLET & human $\alpha$-lactalbumin & oleic acid & column chromatography & $\begin{array}{l}\text { (Pettersson- } \\
\text { Kastberg et } \\
\text { al. 2009) }\end{array}$ \\
\hline $1: 2.9 \pm 0.1$ & & HAMLET & human $\alpha$-lactalbumin & oleic acid & heating to $17^{\circ} \mathrm{C}$ & $\begin{array}{l}\text { (Knyazeva et } \\
\text { al. 2008) }\end{array}$ \\
\hline $1: 9$ & & HAMLET & human $\alpha$-lactalbumin & oleic acid & heating to $45^{\circ} \mathrm{C}$ & $\begin{array}{l}\text { (Knyazeva et } \\
\text { al. 2008) }\end{array}$ \\
\hline $1: 11.5$ & & $\begin{array}{l}\text { recombinant } \\
\text { His-tagged } \\
\text { HAMLET }\end{array}$ & $\begin{array}{l}\text { recombinant human } \\
\alpha \text {-lactalbumin }\end{array}$ & oleic acid & heating method & $\begin{array}{l}\text { (Zhang et al. } \\
\text { 2013) }\end{array}$ \\
\hline $1: 7.5$ & & HAMLET & $\begin{array}{l}\text { recombinant human } \\
\alpha \text {-lactalbumin }\end{array}$ & oleic acid & heating method & $\begin{array}{l}\text { (Nakamura } \\
\text { et al. 2013) }\end{array}$ \\
\hline $1: 10 \pm 1.4$ & & BAMLET & bovine $\alpha$-lactalbumin & oleic acid & heating method & $\begin{array}{l}\text { (Hoque et al. } \\
2013)\end{array}$ \\
\hline
\end{tabular}


J Pharm Pharm Sci (www.cspsCanada.org) 18(4) 773 - 824, 2015

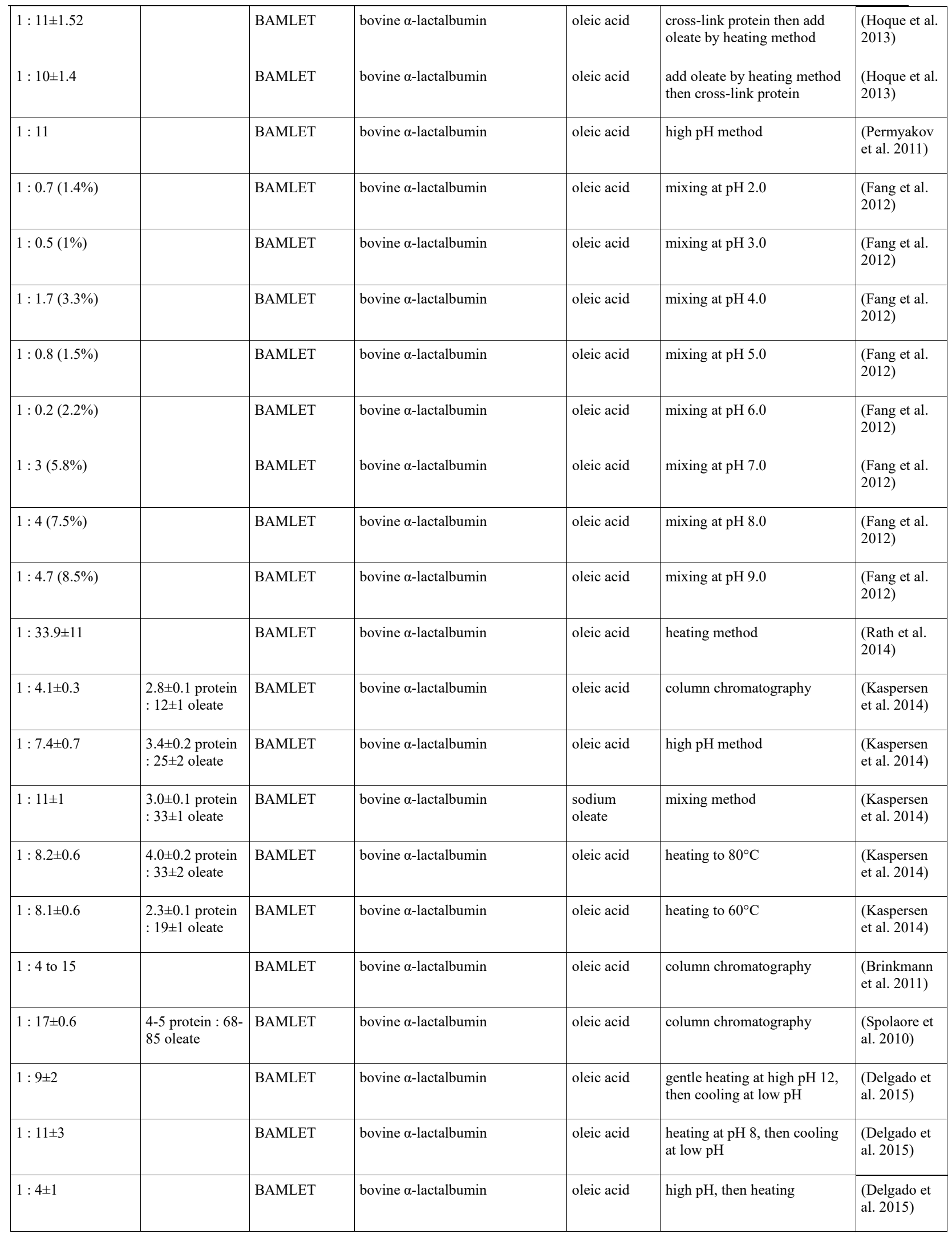


J Pharm Pharm Sci (www.cspsCanada.org) 18(4) 773 - 824, 2015

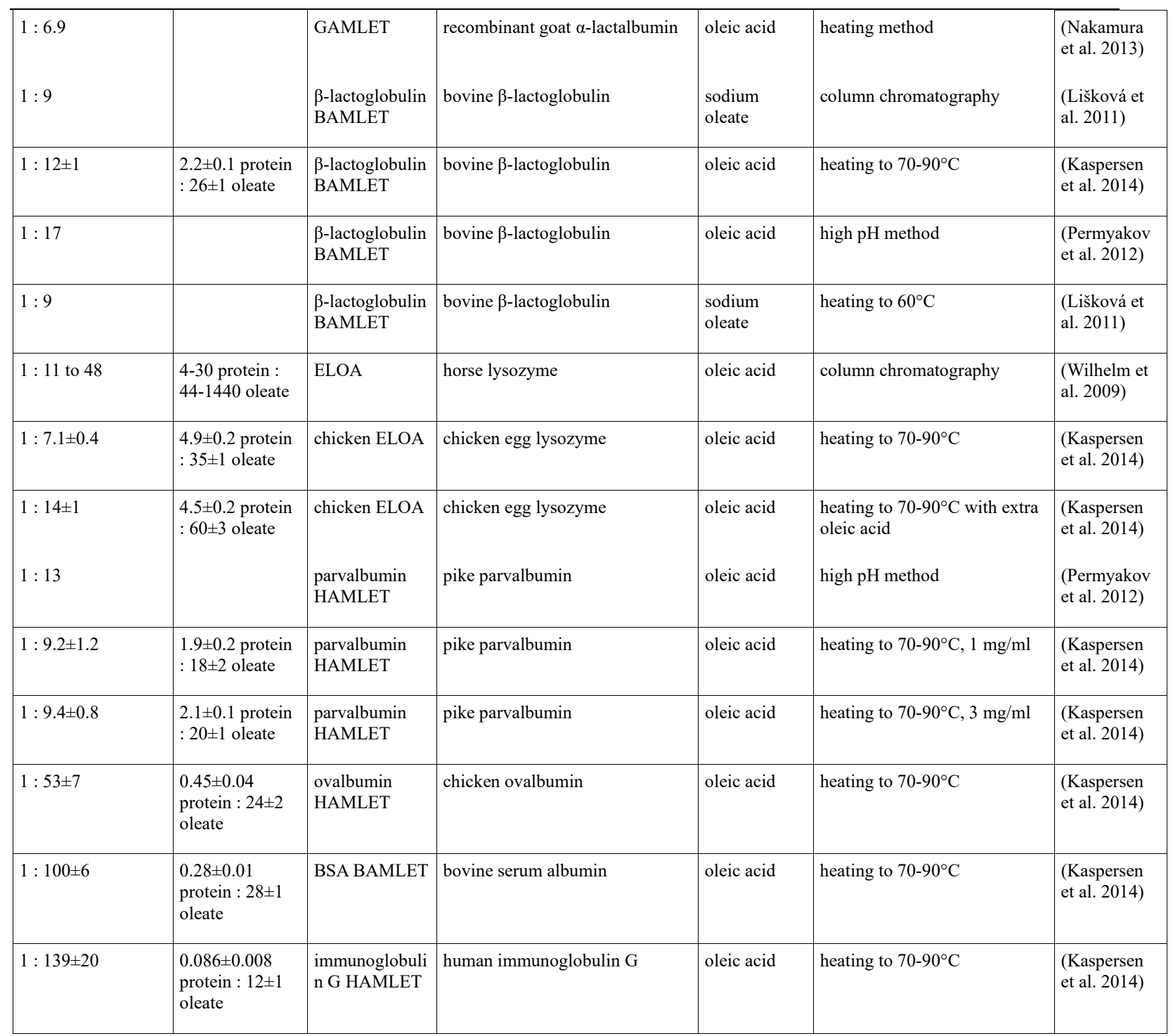

